\title{
STATUTORY LIMITATION PERIODS IN ALBERTA STATUTES
}

The compiled materials on Statutory Limitation Periods in Alberta Statutes which appear in this edition of the Alberta Law Review were prepared by the Institute of Law Research and Reform pursuant to a proposal made by Mr. Gerald Masuch, the editor of the Alberta Law Review in 1973-1974.

Whereas the materials gathered represent an attempt to be as thorough as possible in locating the limitation periods contained in the Revised Statutes of Alberta 1970 and the subsequent yearly volumes of the Alberta Statutes through 1973, the Institute of Law Research and Reform does not represent the absolute accuracy or absolute coverage of this material which should, in this event, not be considered as exhaustive. It is to be noted in this regard, that no perusal was made of the Alberta Regulations to determine, inter alia, the existence or otherwise of any limitation periods which might affect the viability of a cause of action or the jurisdiction of an administrative board or tribunal.

It is hoped that this compilation of limitation periods will serve as a handy reference to members of the legal profession in the Province as well as others who may have dealings which require the strict compliance with statutory procedures. The use of such a reference should not, of course, be a substitute for direct reference to the statute(s) in question.

In relation to the foregoing, reference should be made to the provisions of the Interpretation Act, R.S.A. 1970, c. 189, (18(1)(k) and (1) and 18(2)-(4), and the definitions of "holiday", "month," and "year" found in section 21(1)). These provisions will be applicable to the computation of the time periods which appearin this material unless a contrary intention appears in a particular statute regarding the computation of time (ss. 3(1) and 3(2)).

Hopefully an updating of the statutory limitation materials will be done on a yearly basis in the future. Thus will an attempt be made to keep the basic materials as current and accurate as possible, while at the same time avoiding the necessity of repeating the rather long and eye wearying exercise which is required if the job is left unattended for a period of 13 years as is the case of this effort in relation to the materials which appeared in (1962) 2 Alberta Law Review, pp. 95-111.

Prepared by:

Staff of The Institute of Law Research and Reform

The University of Alberta 
Statute

Agricultural Chemicals Act, R.S.A. 1970, c. 4

Agricultural

Development

Act, 1972, c. 5

Agricultural Relief Advances Act, R.S.A. 1970 , c. 6.

Agrologists Act,

R.S.A. 1970 , c. 10

The Arbitration Act

R.S.A. 1970 , c. 21

The Artificial Insemination of Domestic Animals Act, R.S.A 1970 , c. 23

\section{Action or Remedy}

8. 17-Any person aggrieved by an act or refusal to act by the Minister with respect to the suspension, cancellation, issuance, or renewal of a licence or permit, or by the act of an inspector with respect to the use or methods of application of an agricul. tural chemical, shall serve notice of appeal in the prescribed form upon the Minister and the chairman of the Agricultural Chemicals Advisory Committee within ...

s. 25(3)-Any person who considers himself aggrieved by a decision of the Minister to cancel a sale may appeal to the Appellate Division of the Supreme Court of Alberta within . . .

s. 17(3)-No complaint or information relating to the offence of disposing of grain that is subject to a lien for advances under this Act may be made or laid except within ...

8. 22(3)-No complaint or information relating to the offence or misuse of a com. modity obtained from the municipality under this Act may be made or laid except within ...

8. 22(4)-Application for admission to examination for membership of the Institute shall be made on a form to be supplied on application to the secretary of the Coordinating Council, and shall be filed with the secretary, at least ...

s. 28(1)-A person suspended or expelled from the Institute may appeal to the Supreme Court of Alberta against the order at any time within...

SCHEDULE A, section 3-The arbitrators shall make their award in writing within ...

SCHEDULE A, section 3-The umpire shall make his award within ...

s. 5(2)-A prosecution under this section may be commenced within ...

\section{Limitation Period}

60 days of the date of the written notice informing him of the act or refusal in respect of which he is aggrieved.

15 days of service upon him of a copy of the order.

12 months from the time when the matter of complaint or information arose.

12 months from the time that the matter of com. plaint or information arose.

4 weeks before the times fixed for the examina. tion.

3 months after the date of the order of the council.

6 weeks of entering on the reference, or of being called on to act by written notice from any party to the submission, or on or before any later day set by the arbitra. tors, in writing signed by them, for making the award.

1 month of expiration of the original or extended time appointed for making the award of the arbitrators, or on or before any later day set by the umpire, in writing signed by him, for making his award.

2 years of the commis. sion of the alleged offence, but not afterward. 


\section{Statute}

Assessment Appeal Board Act, R.S.A. 1970, c. 24

Assignments of Book Debts Act, R.S.A. 1970, c. 25

The Bee Act, 1972 , c. 15

Bee Diseases Act, R.S.A. 1970 , c. 26

\section{Action or Remedy}

8. 15(1)-An appeal by a municipality or the Minister from an equalization of assessment order may be commenced by giving notice in writing to this Board within ...

8. 16-An appeal from an assessment made by the Chief Provincial Assessor or the Commissioner may be commenced by giving notice in writing to this Board within ...

8. 5(1)-Registration of an assignment shall be effected within...

8. 6(1)-An assignment that has been registered ceases to be valid unless a renewal statement is registered, in accordance with this section, before the expiration of ...

8. 6(3)-The renewal statement and the affidavit prescribed by this section, or duplicate originals thereof, shall be registered in the Central Registry within ...

8. 6(4)-The assignment ceases to be valid unless a further renewal statement is registered in accordance with this section within...

8. 5(1)-A person who sells beekeeping equipment to any person in Alberta shall provide the Supervisor with the name and address of the purchaser and the quantities in which the beekeeping equipment was sold within ...

8. 5(2)-A person who sells bees to any person in Alberta shall send to the Supervisor the name and address of the purchaser and the quantities in which the bees were sold within ...

8. 5(3)-A person who conveys bees, commonly known as "package bees", shall send to the Supervisor the name and address of the purchaser and the quantities in which the bees were conveyed with. in ...

8. 8(3)-A person who buys any used beekeeping equipment shall notify the Supervisor within ...

8. 8-All bees among which contagious or infectious disease exists are in quarantine upon the premises of their owner, who shall notify the Department within...

\section{Limitation Period}

60 days of the date of the sending out of the notifications by the Assessment Equalization Board.

30 days of the date of the sending out of the notice of assessment.

30 days from the date of its execution.

3 years from its registra. tion as against a creditor and as against a sub. sequent purchaser whose assignment has been registered or is valid without registration.

30 days after the making of the affidavit.

3 years from the registration of the first renewal statement, and thereafter within 3 years of the registration of the last preceding renewal statement.

30 days of a request by the Supervisor.

30 days of the sale.

30 days of the conveyance.

15 days of the date it was bought.

3 days of the occurrence of the disease. 
Statute

The Beverage

Container Act,

1972 , c. 16

The Bills of Sale Act, R.S.A. 1970 , c. 29

The Boilers and Pressure Vessels Act, R.S.A. 1970 , c. 32

Builders' Lien Act R.S.A. 1970 , c. 35

\section{Action or Remedy}

s. 2.1(4)-The depot operator may request the manufacturer to reimburse him for each container accepted by him, and to pay an additional sum of 1 cent for each container in respect of which a refund was made, after ...

8. 6(1)-Registration of a bill of sale shall be effected by filing the bill of sale, together with such affidavits as are by this Act required, within ... .

8. 10(1)-Where a bill of sale comprises an itinerant machine it shall be filed, together with such affidavits and documents as are required by this Act in respect of registration generally, within ...

8. 12(1)-Where a registered bill of sale evidences a mortgage of chattels, unless a renewal statement accompanied by the affidavit prescribed by this section is registered, it ceases to be valid after the expiration of . .

8. 12(5)-The bill of sale ceases to be valid unless a further renewal statement accom. panied by the prescribed affidavit is registered in accordance with this section within ...

8. 13(2)-Where the mortgage relates to an itinerant machine it shall be registered by filing the instruments and affidavits prescribed in this section in the office of the registration clerk in the Motor Vehicle Branch within ...

8. $13(3)$-Where the mortgage relates to a chattel other than an itinerant machine, it shall be registered by filing the instruments and affidavit prescribed in this section in the Central Registry within ...

8. 44(2)-An appeal lies to the Minister from an order or decision of the chief inspector, or an order cancelling or sus. pending an inspection certificate, if made within ...

8. 30(1)-A lien in favour of a contractor or a sub-contractor may be registered ...

8. 30(2)-A claim of lien for materials may be registered ...

s. 30(3)-A lien for the performance of services may be registered...

\section{Limitation Period}

10 days from the date of a notice under section 2.1(3) or the manufacturer has made an inspection pursuant to section 2.1(3), whichever is the earlier.

30 days from the date of its execution in the Central Registry.

21 days after the making thereof, in the office of the registration clerk in the Motor Vehicle Branch.

3 years from its registration.

3 years after the registration of the first renewal statement and thereafter within 3 years of the last preceding renewal statement.

21 days after the grantee receives notice of the permanent removal into the Province of the itinerant machine.

30 days after the grantee receives notice of the permanent removal into the Province of the chattel.

30 days of the order.

at any time up to the completion or abandonment of the contract or sub-contract, as the case may be, and within 35 days after completion or abandonment.

at any time during the furnishing of the $\mathrm{ma}$ terials and within 35 days after the last of the materials is furnished.

at any time during the performance of the services and within 35 days after the performance of the services is completed. 
Statute

The Bulk Sales Act

R.S.A. 1970, c. 37

\section{The Cemetery Companies Act, R.S.A. 1970, c. 40}

Change of Name Act, R.S.A. 1970 , c. 41

amended by 1973 , c. 63

The Chartered Physiotherapists Act, R.S.A. 1970 , c. 43

The Child Welfare Act, R.S.A. 1970 c. 45
Action or Remedy

8. 30(4)-A lien for wages may be regis tered ...

8. 32(1)-A lien that has been registered ceases to exist unless

(a) an action is commenced to realize upon the lien or in which the lien may be realized upon under this Act, and

(b) a certificate of lis pendens in the prescribed form is registered in the appropriate land titles office within ...

8. 38(5)-A lienholder upon whom a notice to prove lien is served loses his lien unless he files his affidavit within ...

8. 12-No action shall be brought or proceedings taken to set aside or have declared void a sale in bulk for failure to comply with the provisions of this Act unless the action is brought within...

s. 3(5)-An appeal may be taken to the Lieutenant Governor in Council from any decision given by the Registrar under this section within ...

8. 5-A company formed under this Act shall file in the office of the Registrar a list of its directors and managers within...

8. 8-A conveyance or transfer is void unless the trustees cause it to be registered in the Land Titles Office of the land registration district within which the land is situated, within...

s. $12(2)$-The notices required under this section shall be published not more than ...

8. 13(2)-Every applicant for a change of surname shall publish in one issue of the Alberta Gazette a notice in the prescribed form or to the like effect stating the name and proposed surname of the applicant not more than ...

8. 17(1)-Any member who has been expelled or suspended from the Association may appeal from the order of the council to the Supreme Court of Alberta at any time within...

8. 23-A prosecution for an offence under this Act may be commenced within ...

8. 27 (1)-A parent, guardian, or other person in whose care the child may have been, or the Director, may appeal to a judge of the Supreme Court within ...

\section{Limitation Period}

at any time during the performance of the work for which the wages are claimed and within 35 days after the completion of the work.

180 days of the date of registration thereof.

15 days of the service of the notice, or within such further period as the court may order on application upon notice.

6 months from the date of the sale.

1 month of the date of the decision.

15 days of their appointment.

12 months after the execution of the conveyance or transfer.

2 months prior to the date of receipt of the application in the office of the Minister.

2 months prior to the date of the receipt of the application in the office of the director.

14 days of the date of the order of expulsion or suspension, or within such further time as a judge of the Supreme Court may order.

2 years from the date of the alleged offence, but not thereafter.

30 days from the making of an order under this Part by a judge of the district court or the juvenile court. 
Statute

The Chiropractic Profession Act, R.S.A. 1970, c. 46

The City Transportation Act, R.S.A. 1970 , c. 47
The Clean Air Act, 1971 , c. 16

\section{Action or Remedy}

8. 27(2)-A copy of the notice of appeal shall be served upon the judge who made the order, and upon the parent or parents of the child, or the guardian or other person in whose care the child may have been, or upon the Director, as the case may be, within ...

s. 27(3)-The judge who made the order appealed from shall forward to the clerk of the court of the judicial district in which the notice of appeal is filed certain documents specified by this subsection within ...

8. 63(1)-Except on the ground that it was procured by fraud, no action or proceeding to set aside an order of adoption shall be commenced after the expiration of ...

8. 8(3)-A member may appeal from a decision of the council under this section to a judge of the district court at any time within ...

s. 10(3)-A prosecution under this Act may be commenced within ...

s. 17(1)-A person affected by a decision of a protection area officer may appeal to the Protection Area Appeal Board by serving notice by registered mail upon the protection area officer and the chairman of the Protection Area Appeal Board within ...

8. 17(2)-The Protection Area Appeal Board shall hold a hearing within ...

8. 18(2)-Leave to appeal from a decision of the Protection Area Appeal Board to the Appellate Division of the Supreme Court of Alberta shall be obtained from a judge of the Appellate Division upon application made within ...

8. 18(3)-Upon leave being obtained the party appealing shall give notice thereof to the respondent within ...

8. 19(1)-The owner of any property within a transportation protection area shall serve notice of the proposed sale upon the city clerk at least...

The owner may complete the sale if the city has not

(a) matched the offer to purchase, in which case the owner shall sell to the city, or

(b) commenced expropriation proceedings after...

8. 7(3)-Where a stop order is made the Minister shall cause a copy of it to be served on the person to whom it is directed not less than ...

\section{Limitation Period}

30 days from the date of the making of the order, or such longer time as a judge of the Supreme Court may order.

7 days from the time the notice of appeal is served upon him.

1 year from the day of the order.

30 days of the date of the decision or within such further time as a judge may order.

2 years from the date of the alleged offence but not afterward.

14 days after notice of the decision is mailed to him, or within 14 days of the date the application is deemed refused.

30 days from the receipt by it of the letter of appeal.

30 days after the making of the decision of the Protection Area Appeal Board.

10 days after the appeal has been set down.

60 days before completing any sale of the property; or,

the 60 day period.

48 hours after making the stop order. 
Statute

The Clean Water Act, 1971 , c. 17

The Coal

Conservation Act, 1973 , c. 65

The Coal Mines Regulation Act, R.S.A. 1970 , c. 52

The Collection Agencies Act, R.S.A. 1970 , c. 55

The Companies Act, R.S.A. 1970 , c. 60
Action or Remedy

8. 7(7)-A person to whom a stop order is directed may appeal to the Minister in accordance with the regulations for an inquiry into the stop order within ...

8. 7(3)-Where a stop order is made the Minister shall cause a copy of it to be served on the person to whom it is directed not less than ...

8. 7(7)-A person to whom a stop order is directed may appeal to the Minister in accordance with the regulations for an inquiry into the stop order within ...

8. 20(2)(a)-Except where there exists, in the Board's opinion, an immediate danger to a person or to public or private property, the Board shall not cancel or suspend a permit or licence under subsection (1) until it has given the holder at least ...

s. 41(2)-The Board may order the suspension of development or operations of a coal mine or coal processing plant until improvements have been effected pursuant to a direction under subsection (1) where the changes are not made within ...

8. 44-Any prosecution for an offence under this Act shall be commenced within ...

s. 55(2)-A complaint under this section shall be made within ...

s. 120(1)-The owner of a mine that is either temporarily or permanently aban. doned shall deposit the plan of the mine with the Director within...

s. 422-A prosecution for an offence against this Act, the regulations, or an order pursuant thereto, may be commenced within ...

8. 7(1)-A person who is refused a licence or whose licence is suspended or cancelled under section 6 may appeal the decision of the Administrator by filing a notice of appeal with the Deputy Attorney General within ...

8. 12(3)-The company or extra-provincial company concerned shall file with the Registrar a copy of the order certified by the clerk of the court within ...

8. 14(5)-Proceedings to recover any loss, damage or costs sustained or incurred by reason of a contravention of section 14(1) may not be commenced after the expiration of ...
Limitation Period

15 days after service upon him of a copy of the order.

48 hours after making the stop order.

15 days after service upon him of a copy of the order.

30 days notice to rectify his default.

90 days from the date of the direction or notice to improve mining practice.

18 months from the time when the subject matter of the prosecution arose, and not afterwards.

14 days of the date on which notice of the appointment of the check-weigher or checkmeasurer was left at the office of the mine.

3 months or such further time as the Director in writing may allow.

12 months from the time when the matter of such prosecution arose, but not thereafter.

30 days after the refusal, suspension or cancellation.

10 days after the entry of an order under section 12(2).

2 years from the date on which the loss, damage or costs were sustained or incurred. 


\section{Action or Remedy}

8. 34(6)-Where an order altering the objects of the company is made under this section the company shall file with the Registrar an office copy thereof, together with a copy of the memorandum as altered, within ...

s. 38(2)-Where an order reorganizing share capital is made under this section, an office copy thereof shall be filed with the Registrar within ...

s. 40(2)-Where an order reducing share capital is made under this section, the company shall file with the Registrar an office copy thereof and of a minute which shall be approved by the court, and which contains such information as is specified by this subsection, within ...

8. 77-No director is liable to an action for wages under this section unless the company is sued therefor, or a judgment is obtained against it, within 1 year after the debt becomes due, and an unsatisfied execution against the company is returned, and the director is sued therefor within ...

s. 79(2)-Every company shall file with the Registrar a notice, in the prescribed form, of its first directors or managers within ...

8. 79(2)-Every company shall file with the Registrar a notice of the change of directors within ...

8. 82(1)-A person who becomes an insider of a company shall file with the Commission a report, as of the day on which he became an insider, of his direct or indirect beneficial ownership of, or control or direction over, capital securities of the company, within ...

8. 82(2)-If a person who is an insider of a company, but has no direct beneficial ownership of or control or direction over capital securities of the company, acquires such direct or indirect beneficial ownership, or control, or direction, he shall file with the Commission a report, as of the date of such acquisition, of the extent of such direct or indirect beneficial ownership, or control, or direction as he has acquired, within ...

8. 82(3)-A person who has filed or was or is required to file a report under this section, and whose direct or indirect beneficial ownership of or control or direction over capital securities of the company changes from that shown or required to be shown in such report, or in the last report filed by him, shall file with the Commission a report of his direct or indirect beneficial ownership of or his control or direction over capital securities of the company within...

\section{Limitation Period}

15 days from the date of the order or within such further time as the court may allow.

15 days from the date of the order or such further time as the court may allow.

15 days from the date of the order or within such further time as the court may allow.

1 year from the time he ceased to be such director.

15 days after their appointment.

15 days after any change among the directors or managers is made.

10 days after the end of the month in which he becomes an insider.

10 days after the end of the month in which such acquisition was made.

10 days following the end of the month in which such change takes place. 
8. 85(2)-An action to enforce any right created by section $85(1)$ may be commenced only within ...

8. 93(1)-Every prospectus issued by or on behalf of a company shall be filed with the Registrar within ...

8. 94(3)-Every person to whom section $94(2)$ (b)(ii) or (iii) applies shall file with the Registrar a copy of the public notice given by him within ...

s. 96(2)-The prospectus referred to in section 96(1) shall be filed with the Registrar within ...

8. 97(1)-Every mortgage of its property created by a company, and every mortgage of its property situate in the Province created by an extra-provincial company, for any purpose stated in this subsection, shall be registered by filing the instrument (or a true copy thereof) by which the mortgage is created or evidenced with the Registrar within ...

8. 97(2)-In a series of debentures containing any charge to the benefit of the debenture-holders, it is oufficient if a true copy of one of the debentures is filed within...

Where more than one issue is made, then a statement setting forth the date and amount of each issue should be filed with. in ...

s. 103-Unless the conditions of issue of the debentures otherwise provide, every company shall complete and have ready for delivery the debentures and the certificates of all debenture stock allotted or transferred within...

8. 104(1)-If a person has an order for the appointment of a receiver or manager of the property of a company, he shall file a copy of the order with the Registrar within...

8. 106(1)-Every receiver or manager shall file an abstract of all receipts and payments with the Registrar within ...

s. 131(1)-A public company shall send by prepaid mail to each shareholder a copy of the financial statement and a copy of the auditor's report within ...
2 years after the date of completion of the trans. action that gave rise to the cause of action.

15 days of the date upon which the prospectus is accepted by the Com. mission pursuant to The Securities Act, or by the equivalent authority in another jurisdiction.

7 days after the date of the notice.

7 days after its issue and before any copies thereof are circulated or distributed.

60 days after the date of its creation (or within 90 days, if created outside the Province).

60 days after the execution of the first debenture of the series.

60 days after the issue is made but an omis sion to do this does not affect their validity.

2 months after the allotment of any of its debentures or debenture stock.

15 days from the date of the order.

1 month of the expiration of 6 months from the date of his appointment, and after every subsequent 6 months, and within 1 month after he ceases to act as re ceiver or manager.

10 days or more before the date of the annual meeting. 
Statute

\section{Action or Remedy}

8. 132(5)-The interim financial statement required by section $132(1)$ shall be sent to each shareholder, within ...

8. 147(1)-A copy of every resolution passed affecting the contents of the articles of a company shall be filed with the Registrar within ...

8. 154(4)-Where an order is made for compromise or arrangement between a company and its creditors an office copy of the order shall be filed with the Registrar within ...

8. 155(4)-Where an order of compromise or arrangement involves the transfer of land a copy of the order shall be filed with the Registrar within ...

8. 166(1)-Every extra-provincial company that carries on business in the Province shall be registered under this Part with. in ...

s. 174(3)-An attorney appointed pursuant to section $174(2)$ who intends to resign shall give not less than ..

8. 175(1)-Every extra-provincial company required to be registered under Part 8 shall file with the Registrar a verified copy of any amendment to its charter or regulations within ...

s. 183(4)-A company formed as a charitable organization shall file a list of all its directors and officers with the Registrar within ...

s. 185 (3)-A company formed for promoting recreation shall file $a$ list of all its directors and officers with the Registrar within ...

8. 189(2)-A person may make application to the court to have a company restored to the register within ...

8. 198(2)(a)-A contributory shall not present a petition for winding-up a company unless the shares allotted to him have been registered in his name during at least ...

8. 198(2)(b)-A petition for winding-up a company on the ground of default in filing the annual report or in holding the annual meeting shall not be presented by any person except a shareholder, nor before the expiration of ...

8. 200(1)-On the making of a winding-up order a copy of the order shall be filed by the liquidator with the Registrar with. in ...

8. 209(2)-An office copy of the order for dissolution of the company shall be filed by the liquidator with the Registrar with. in ...

\section{Limitation Period}

60 days of the date to which it is made up.

15 days from the passing thereof.

15 days from the date of the order or within such further time as the court may allow.

7 days after the making of the order.

30 days after commencing to carry on business in the Province.

60 days' notice to the company at its head office.

1 month after the date when the amendment takes effect.

14 days after the date of its annual meeting.

14 days after the date of its annual meeting.

1 year from the date when the company was struck off the register.

6 months of the 18 months prior to the winding-up proceedings.

14 days after the last day on which the meeting ought to have been held.

15 days from the date of the order.

15 days from the date of the order. 
Statute

The Conditional Sales Act, R.S.A. 1970 , c. 61

\section{Action or Remedy}

s. 223(4)-Every liquidator or provisional liquidator shall file with the Registrar a notice of his appointment within ...

8. 241(1)-Every liquidator in a voluntary winding-up shall file with the Registrar a notice of his appointment or resignation, in the prescribed form, within ...

s. $252(1)$-If the voluntary winding-up is longer than one year, the liquidator shall file a summary of receipts and payments with the Registrar within ...

8. 254(3)-At the end of the voluntary winding-up the liquidator must file an account with the Registrar within ...

8. 254(7)-Where the court makes an order deferring the date of dissolution of the company, the copy of the order will be filed with the Registrar within ...

s. 255(2)-Where an order dispensing with the convening of a meeting of the members is made the liquidator shall file an office copy of the order with the Registrar within ...

s. 257-Any creditor or contributory may appeal a compromise and arrangement order made under 8. 247 within ....

8. 272(1)-Where the company has been dissolved, any interested person can make application to the court that the dissolution be made void at any time within ...

8. 272(2)-An applicant shall file a copy of an order made under 272(1) with the Registrar within ...

8. 297-An information in respect of an offence against this Act may be laid within ...

s. 4(1)-Subject to sections 5 and 6 the conditional sale agreement or a true copy thereof shall be registered in the Central Registry within ...

8. 5(5)-The conditional sale agreement shall be filed under section 5(1) within ...

8. $7(1)(a) \&(b)-T h e$ seller or bailee under a conditional sale agreement loses the right to set up a property right or right of possession against a purchaser or mortgagee of or from the buyer or bailee in good faith for valuable consideration, or against judgments, executions or attachments against the buyer or bailee, unless a statement of the amount still due for principal and interest on the sale or bailment, and of all payments made on account thereof, is registered in the Central Registry or in the Motor Vehicle Branch, before the expiration of ...

\section{Limitation Period}

7 days after his appointment.

7 days of the appointment or resignation.

7 days of the year-end meeting.

7 days of the final meeting.

7 days of the making of the order.

7 days after the making thereof.

2 weeks from the date when the compromise or arrangement is entered into.

1 year of the date of dissolution.

7 days of the making of the order.

2 years from the time when the matter of the information arose, but not thereafter.

30 days from the time of the actual delivery of the goods to the bailee or buyer.

21 days after the making thereof.

3 years from the registration of the conditional sale agreement. 
Statute

The Condominium Property Act, R.S.A. 1970, c. 62.

The Controverted Elections Act, R.S.A. 1970, c. 66

\section{Action or Remedy}

8. 8-Nothing in this Act relating to registration applies to a sale or bailment of rolling stock or equipment for use on railways if the conditional sale agreement relating thereto or a true copy thereof is filed with the registration clerk of the Motor Vehcile Branch within ...

s. 14(2)-Where the conditional sale agreement comprises an itinerant machine, it shall be registered in the Motor Vehicle Branch within ...

8. 14(3)-Where the conditional sale agreement comprises goods or chattels other than an itinerant machine, it shall be registered in the Central Registry within ...

8. 36(1)-Two copies of the registered condominium plan or any amendment thereto including all endorsements thereon, certified as prescribed by the regulations, shall be furnished by the corporation to the assessing authorities within ...

8. 3-A defeated candidate or any duly qualified elector may petition against the undue election of a candidate any time within ...

8. 6-A copy of the petition under section 3 shall be served on the respondent within ...

8. 9-The respondent shall file with the Clerk a notice in writing specifying an address for service within...

8. 10-The respondent may apply to the judge to set the petition aside and have it removed at any time within ...

s. 11-If the petitioner claims the seat for any candidate other than the one returned as elected, the respondent may file with the clerk a statement in Form $B$ in the Schedule, and serve a copy of the statement on the petitioner within...

8. 12-The petitioner may apply to the judge to set the statement aside and have it removed from the files of the court within ...

8. 13-The respondent may apply to the judge for particulars, or for further and better particulars, of the facts and grounds relied on to sustain the prayer of the petition at any time within ...

8. 17-The respondent may apply to the judge to dismiss the petition if the petitioner does not apply to the judge to appoint a time and place for the trial of the petition within...

\section{Limitation Period}

30 days from the execution of the agreement.

21 days after the seller or bailor receives notice of the permanent removal into Alberta of the itinerant machinery comprised in the agreement.

30 days after the seller or bailor receives notice of the permanent re moval into the Province of the goods or chattels.

28 days after the registration of a condominium plan or any amendment thereof.

30 days after the name of the candidate elected has been published in The Alberta Gazette.

20 days of the filing thereof.

10 days after being served with a copy of the petition.

20 days after the service upon him of the petition.

20 days after service upon him of the copy of the petition.

10 days after service upon him of the statement.

20 days after service upon him of the petition.

1 month after the petition is at issue. 
Statute

The County Act, R.S.A. 1970, c. 71

The Credit and Loan Agreement Act, R.S.A. 1970 , c. 73

The Credit Union Act, R.S.A. 1970, c. 74

amended by S.A. 1973 , c. 66

Criminal Injuries Compensation Act, R.S.A. 1970, c. 75
Crown Agencies

Employee Relations Act, R.S.A. 1970, c. 79 , amended by S.A. 1973 , c. 19

\section{Action or Remedy}

s. 6(2)-The County shall notify the Minister and shall conduct a plebiscite if ten per cent of the proprietary electors notify the county of their desire for a change in county status within ...

8. 31-Insofar as they are not inconsistent with this Act, the following provisions of the Municipal Elections Act, R.S.A. 1970, c. 245 and the Municipal Government Act, R.S.A. 1970 , c. 246 , shall apply to every county:

Note: sections containing limitations

8. 24(2)-A prosecution against the credit grantor who fails to comply with this Act or the regulations may be commenced within ...

s. 73(2)-Upon receipt of notice of a proposed dissolution, the name of the Credit Union will be struck off the register and the Credit Union will be dissolved unless cause is shown to the contrary within ...

$58(1)(a)-$ Where the Director is of the opinion that the affairs of a Credit Union are being mismanaged or are being conducted in an unsound manner he shall make an order requiring the credit union to reorganize its affairs to the satisfaction of the Director within ...

8. 7(2)-The Board shall not make an order for compensation;

(a) where the application for compensation is made after the expiration of ...

or

(b) where the injury or death and the act or omission or the event resulting in the injury or death are not reported within ...

8. 4(2.1)-Where an agreement is in effect in respect of some of the employees of the employer, either the employer or the Association may give notice to the other to commence negotiations relating to other employees, in respect of whom no agreement is then in effect, not less than ...
Limitation Period

30 days of the posting of the notice referred to in subsection (1).

Municipal Election Act -8. $45(1)$, 8. $126(3)$ s. $132(1)$, s. 166 , s. 169 , s. 172(2), 8. 185(1), 8. 189; Municipal Government Act-8. 14(3), 8. 135(1), 8. $157(4)$, 8. $158(7)$, s. $183(9)$, s. $221(2)$, s. $239(5)$, s. $311(2)$, s. $343(2)$, s. $384(1)$, s. $385(1)$, s. $387(1)$ and (2), 8. 388 , s. $397(3)$, 8. $397(9)$, 8. 407(3), and (6), 8. $409(1)$ and (2), 8 . 410(2) and (4), 8. 425.

3 years after the commission of the offence, but not thereafter.

2 months after receipt of the notice.

90 days or such longer period as the director may from time to time prescribe.

1 year from the injury or death, as the case may be,

a reasonable time after the happening thereof to the proper law enforcement authority.

but notwithstanding clause (a), the Board may, where it considers it to be advisable, ex tend the time for applying for compensa. tion.

60 days and not more than 90 days immediately prior to the expiry of the existing agree ment. 


\section{Statute}

Crown Cultivation Leases Act, R.S.A. 1970 , c. 80

The Defamation Act R.S.A. 1970 , c. 87

The Dental Association Act, R.S.A. 1970 , c. 90

The Dental Auxiliaries Act, R.S.A. 1970 , c. 91

The Dental

Mechanics Act, R.SA. 1970 , c. 92

The Department of Environment Act, 1971 , c. 24.

as amended by 1972 , c. $32,8.7$

\section{Action or Remedy}

s. 5(4)-The Minister and the lessee of the land held under a crop share cultivation lease have the same right of appeal and complaint under The Municipal Taxation Act as an owner of assessable land has under that Act, i.e., an appeal pursuant to 8. 56 of the Municipal Taxation Act may be made within ...

s. 14(1)-No action lies unless the plaintiff has given to the defendant within...

In the case of a daily newspaper...

and in the case of any other newspaper or where the defamatory matter was broadcast...

8. 9(1)-A member of the Association desiring to contest the validity of an election held under this Act may present a petition to set aside the election to a judge of the Supreme Court of Alberta within ...

s. 32(3)-The Registrar shall suspend from privileges of membership a member against whom a penalty or fine is adjudged by the board if such member does not comply with the judgment within ...

8. 43(1)-A person whose name has been removed from the register or who has been suspended from practice by order of the board may appeal from the order to a judge of the Supreme Court in chambers at any time within...

8. 59-No prosecution shall be commenced in respect of a contravention of this Act except within ...

8. 10(1)-Notice of the date, time and place of the meeting of the committee for taking evidence or otherwise ascertaining the facts shall be served on the dental auxiliary whose conduct is the subject of inquiry at least ...

8. 14(1)-A person whose name has been removed from the register or who has been suspended from practice by order of the committee may appeal from the order to a judge of the Supreme Court at any time within ...

s. 14(6)-A member suspended, or expelled from the Society may appeal from the decision of the council to a judge of the Supreme Court of Alberta at any time within ...

8. 16(3)-The Minister shall cause a copy of a stop order to be served on the person to whom it is directed not more than ...

\section{Limitation Period}

21 days after the mailing or personal service of the notice required by 8. 54 of that Act upon the person appealing.

3 months after the publication of the defamatory matter has come to his notice or knowledge;

7 days notice in writing; 14 days notice in writing.

30 days from the date of the election.

30 days after receiving a written notice from the Registrar of the findings of the board.

2 months after the date of the service of the order of the board upon him.

12 months after the date of the contravention.

10 days prior to the meeting.

2 months after the date of the service of the order of the committee upon him.

14 days from the date of the order or the resolution of suspension or expulsion, or within such further time as a judge of the Supreme Court of Alberta may order.

48 hours after making a stop order. 
Statute

The Department of Public Works Act, R.S.A. 1970, c. 105. as amended by 1972 , c. 106.

The Disaster Services Act, 1973 , c. 69

The Domestic Animals (Municipalities) Act, R.S.A. 1970, c. 112

The Domestic Relations Act, R.S.A. 1970 , c. 113

The Dower Act, R.S.A. 1970, c. 114

\section{Action or Remedy}

8. 16(7)-A person to whom a stop order is directed may appeal to the Minister for an inquiry into the stop order within ...

8. 7.1(2)-The Government of Alberta may dispose of all lost or unclaimed property in its possession through the Alberta Opportunity Company if the property is not claimed within ...

8. 7.1(4)-No claim may be made to the property or to the proceeds of the sale of the property after...

8. 15(4)-An order of the LieutenantGovernor in Council for a declaration of a state of emergency pursuant to subsection (1) expires at the end of ...

8. 9(5)-A grazing association may sell an animal which was found on community pasture and retain the proceeds for its own use if it has published an advertisement in accordance with $\mathbf{s . 9 ( 3 )}$ and no claim of ownership is filed within ...

s. 20(2)-Before its final passage by council, at least $15 \%$ of the proprietary electors may petition for the submission of a proposed by-law to a vote within ...

8. 29(4)-Notwithstanding subsection (3), the owner of an impounded animal or his agent, may appeal to the council in writing against any amounts claimed as damages or costs of impounding, not later than ...

8. 29(7)-The owner or person impounding an animal may appeal either in writing or in person, to the council against the recommendation made under section 29(5), or (6) within ...

s. 27(8)-An appeal from an order or a refusal to make an order pursuant to this section may be taken either by way of stated case under Part XXIV of the Criminal Code, or to the district court of the district in which the order or refusal was made, if the appellant serves upon the magistrate who dealt with the matter, and the opposite party, notice in writing in the form specified by this subsection, within...

8. 28(1)-A married woman or any other person on her behalf may procure from a magistrate a summons against her husband if the sum ordered to be paid is not paid together with costs, if any, before the expiration of ...

8. 12(4)-No action for damages pursuant to section 12 shall be commenced except within ...

\section{Limitation Period}

15 days after service upon him of a copy of the stop order.

3 months from the time the property came into possession of the Government.

1 year from the date the property came into the possession of the Government.

14 days unless continued by a resolution of the Assembly.

15 days after the date of publication of the ad. vertisement.

30 days from the publication of the notice pursuant to section 20(1) to finally pass the bylaw.

15 days after the im. pounding of the animal.

21 days of the mailing of the notice of the recommendation.

20 days of the date of the order or refusal sought to be appealed.

21 days from the making of the order or such lesser period as may be provided in the order and as often as the pay. ment is in arrears.

(a) 6 years from the discovery by the spouse of the disposition, and (b) 2 years after the death of the married person. 
Statute

The Drainage

Districts Act,

R.SA. 1970, c. 115

\section{Action or Remedy}

8. 14(2)-A spouse may apply by way of originating notice to a judge of the $\mathrm{Su}$ preme Court for an order directing payment out of the Assurance Fund of unsatisfied judgment arising out of section 12, and such notice shall be served upon the Registrar and upon the Attorney General within ...

8. 14(7)-No petition for the formation of a district shall be brought into question or declared to be invalid for any reason in any proceeding which has not been commenced within ...

8. 53(8)-If an owner is dissatisfied with the apportionment of work or material or expenses he may appeal to the council in writing by registered mail within ...

8. 118-The Minister may, in his discretion, order an account of a ballot or poll and give directions for the conduct of the recount if the conditions of subsections (a) and (b) are fulfilled within ...

8. 119(1)-The Minister may make, or appoint some other person to make inquiries upon an election, cause evidence to be taken under oath or by solemn declaration, and by order require the attendance of witnesses or production of documents if the conditions of subsections (a) and (b) are fulfilled within ...

8. 142(1)-A person desiring to make a complaint on an assessment and relying on grounds set out in section 141 may notify the secretary in writing of the particulars and grounds of his complaint, in Form $R$ in the Schedule, within ...

8. 143(3)-Notice of the hearing of the complaint shall be sent by registered letter to the post office address shown on the assessment roll or indicated in the complaint, at least...

8. 155-A person wishing to appeal a decision from the court of revision to the district court pursuant to section 154 shall serve upon the secretary a written notice of his intention to appeal within ...

8. 171(1)-The treasurer may by himself or his agent levy the rates with costs by distress in the same manner as a landlord may recover rent in arrears if a person fails to pay the rate shown by the assess. ment roll within ...

\section{Limitation Period}

30 days before the date on which the originating notice is returnable.

1 year after the day upon which the petition was delivered to the

Minister.

2 weeks after the date of the mailing to him of the notice of apportion. ment.

5 days after the date of the transmission of the statement of the result of the poll to the Minister.

2 weeks after the election.

20 days after the mailing of the assessment notice.

15 days before the sitting of the board.

8 days after the decision, if any, of the court of revision or after the omission, neglect or refusal complained of.

30 days from the mailing of a notice to pay. 
Statute

The Election Act, R.S.A. 1970, c. 117

as amended by 1972 , c. 107 , 8. 1

\section{Action or Remedy}

8. 184(1)-Where pursuant to this Act a parcel of land becomes vested in the board, or a purchaser's agreement for sale in respect of a parcel of land is cancelled and all other encumbrances are discharged, the parcel of land shall not be offered for sale until the expiration of ...

8. 184(2)-Upon the expiration of the term of 12 months, each such parcel then vested in the board that has not been sold sooner in compliance with section 184(1) shall be offered for sale by public auction within ...

8. 184(6)-If a person interested in a parcel of land to be offered for sale by public auction pays the rates due in respect thereof together with the costs of rate enforcement and sale proceedings, the parcel shall not be offered for sale until the expiration of ...

8. 8(b)-A person who has received a writ of election and refuses to perform the duties of a returning officer is guilty of an offence under this Act unless he has a right to exemption under 8.7 and has claimed exemption by sending letters setting out grounds for exemption to the Clerk of the Legislative Assembly within...

8. 13(1)-Upon the receipt of the writ of election the returning officer shall publish by proclamation the matters provided for in subsections (a) to (f) at least...

s. 13(2)-The proclamation shall be published in accordance with the provisions of subsection (a) and subsection (b) at least ...

s. 13(5)-The returning officer may correct obvious errors and omissions on the proclamation not less than ...

8. 30(2)-An information may be laid or a suit may be brought by any elector of the elector division, or by anyone authorized by the Clerk of the Legislative Assembly in that behalf, against an enumerator or returning officer under section $30(1)$ within ...

\section{Limitation Period}

12 months after the date of such vesting or can: cellation and discharge, unless all the persons who had any interest in the parcel of land immediately before the vesting or cancellation and discharge, request in writing that the parcel of land be offered for sale at an earlier date.

90 days.

12 months from the date of the payment and thereafter not before the expiration of 12 months from the date of pay. ment of the accrued arrears and penalties for each subsequent year, provided such payment is made before the parcel is offered for sale in that year.

2 days next after the receipt of the writ of election.

8 days before the day fixed in the writ for the nomination of candidates.

8 days before nomination day, neither the last day allowed for publication nor nomination day being reckoned in the eight days.

48 hours before the time fixed in the proclamation for the nomination of candidates.

1 month from the time of the close of the revision of the electoral list. 
Statute

\section{Action or Remedy}

s. 33-Four or more electors may nominate a candidate by filing with the returning officer a nominating paper in Form 16, signed before a justice of the peace, a commissioner for oaths, a notary public, or the returning officer, at any time after...

8. 43(1)-A candidate may withdraw his nomination by filing with the returning officer a declaration in writing to that effect signed by himself and duly witnessed at any time after his nomination but not later than ...

8. $43(3)-T h e$ sum deposited by a candidate shall be returned to him if, pursuant to subsection (1), he withdraws within ...

8. 43(4)-The sum deposited by a candidate shall be transmitted by the returning officer to the Clerk of the Legislative Assembly and by him placed to the credit of the General Revenue Fund of the Province if the candidate withdraws after the expiration of ...

8. 58(3)-The returning officer shall deliver to each deputy returning officer one ballot box, which shall contain election material of the nature, number or quantity set out in Form 26 at least ...

8. 105(1)-An application by a candidate for an appeal from any decision of the returning officer, and/or for a recount or final addition of the votes cast at the election, must be made pursuant to this subsection within ...

8. 105(3)-A candidate served with notice of an application limited to an appeal or appeals from any decision or decisions of the returning officer may make application for such further appeal or appeals or recount or final addition as is provided for in this section within ...

s. 105(4)-The applicant shall give to the candidate, in the manner provided in 8.35 , and to the returning officer and the election clerk or clerks, at least ... .

8. 107(3)-The judge shall forthwith certify the result to the returning officer who shall then forthwith declare elected the candidate having the largest number of votes, if no notice of appeal is given to the judge within ...

8. 108(1)-A party may appeal from the decision of the judge upon the recount or final addition by giving to the opposite party or parties, and to the judge, notice in writing of his intention to appeal, limited, if so desired, to specified ballot papers, if he sends such notice within ...

\section{Limitation Period}

the issue by the returning officer of the proclamation mentioned in section 13 and before 2 o'clock in the afternoon of the day fixed for nomination.

48 hours before the opening of the poll.

48 hours after 2 o'clock in the afternoon of nomination day.

48 hours.

2 days before polling day.

8 days after the day on which the returning officer has announced the result of the count and declared the name of the candidate elected.

2 days after being served with such notice.

4 days notice in writing of the time and place appointed for the hearing and determina. tion of the appeal.

2 days after the completion of the recount or final addition.

2 days after the completion of the recount or final addition. 
Statute

The Electrical Power and Pipe Line Assessment Act, R.S.A. 1970, c. 119.

\section{Action or Remedy}

8. 108(6)-The time appointed for hearing the appeal shall not be more than ...

8. 111(1)-A candidate or his agent may inspect any election papers in the custody of the Clerk of the Legislative Assembly, except ballot papers, within ...

8. 111(2)-No person shall be allowed to inspect any election papers except upon an order of a judge of the Supreme Court, which, if and when made, the Clerk of the Legislative Assembly shall obey after the expiration of ...

8. 152(1)-Part XXIV of the Criminal Code governs proceedings for the imposition of punishment by fine, penalty, or imprisonment for violations of this Act; by section 721(2) of that Part, no proceedings shall be instituted more than ...

8. 157-Except as herein otherwise provided no proceedings for the violation of any provision of this Act shall be commenced unless within ...

8. 159(1)-The right of a person who has any monetary claim against a candidate for or in respect of an election is barred unless that person sends in the claim to be official agent of the candidate within ...

8. 159(2)-In case of the death within the said month of any person having such monetary claim, the right to recover the claim is barred unless his legal representative sends in the claim within ...

8. $161(1)(a)-A$ detailed statement of all election expenses shall be made out in accordance with Form 48 and otherwise in accordance with this section, and shall be delivered to the returning officer within ...

8. 161(1)(b)-Where by reason of the death of the creditor, no claim has been sent within such period of two months, then within ...

8. 161(3)-The returning officer shall publish the statement in a newspaper published or circulating in the electoral division and shall mail a copy of the statement, together with a copy of the newspaper in which the statement was published, to the Clerk of the Executive Council within ...

8. 9(1)-The owner or operator of a pipeline or works that is or may be liable to assessment under this Act, shall transmit to the Provincial Assessor such information, and in such manner, as the Provin. cial Assessor may require for the purpose of making an assessment under this Act on or before ...

\section{Limitation Period}

10 days from the date of the date of the appointment.

30 days after the name of the candidate elected has been published in The Alberta Gazette.

the 30 days referred to in subsection (1).

6 months after the time when the subject matters of the proceedings arose.

6 months after the violation was committed.

1 month of the day of the declaration of the result of the election.

1 month after probate or administration has been obtained.

2 months after the polling day, or,

1 month after the claim has been sent in.

14 days after receiving the statement.

the 31st day of October in every year. 
Statute

The Electrical

Protection Act,

R.SA. 1970 , c. 120

The Elevators and

Fixed Conveyances

Act, R.S.A. 1970,

c. 121

The Employment Agencies Act, R.S.A. 1970 , c. 123

The Energy Resources Conservation Act, 1971 , c. 30
Action or Remedy

8. 10-A person or municipality mentioned in section $9(1)$ may appeal to the board by serving written notice upon the board and the Provincial Assessor within ...

8. 11-The board in hearing appeals is governed by this Act and The Assessment Appeal Board Act, R.S.A. 1970, c. 24, s. $15(1)$ of which provides that an appeal by a municipality or the Minister from an equalization of assessment order may be commenced by giving notice to the Board within ...

8. 14(2)-Where an error, etc., has influenced a person to whom the assessment slip is directed to refrain from appealing against the assessment within the time allowed, that person is entitle to receive a corrected assessment slip and he may appeal to the board against the assessment as shown on the corrected assessment slip within ...

8. 11(4)-A prosecution under this section may be brought within ...

s. 22(2)-An information and complaint may be laid within ...

s. 7(1)-A person who is refused a licence or whose licence is suspended or cancelled may appeal the decision of the Administrator by filing a notice of appeal with the Minister within ...

s. 35(2)-In contentious matters, where the Board considers it necessary, notice of an application to or a hearing by the Board shall be given by mail, newspaper publication or such other means as the Board considers proper, and shall be given not less than ...

8. 41(1)-Any person affected by an order or direction made by the Board without the holding of a hearing may apply to the Board for a hearing within ...

8. 41(2)-Any person affected by an order or direction made by the Board after a hearing and to whom notice of the hearing was not directly given may apply to the Board to vary, amend or rescind it within...

s. 41(5)-When an application is made under this section, the Board shall hold a public hearing of the application, and may confirm vary or rescind the order or direction as to the Board seems just after not less than ...

\section{Limitation Period}

30 days after the mailing of the assessment notice by the Provincial Assessor.

60 days of the order.

30 days of the mailing of the corrected assessment slip.

2 years of the commission of the alleged offence.

2 years of the commission of the alleged offence.

30 days after the refusal, suspension or cancellation.

10 days prior to such application or hearing.

30 days after the date upon which the order or direction was made.

30 days after the date upon which the order or direction was made.

10 days' notice to all persons affected by the order of direction. 


\section{Statute}

The Engineering and Related Professions Act, R.S.A. 1970, c. 124

\section{Action or Remedy}

s. 42(2)-Leave to appeal pursuant to section $42(1)$ shall be obtained from a judge of the Appellate Division upon application made within ...

8. 42(4)-The Board shall forward to the Registrar the transcript and record of the hearing and its findings and reasons for the order or direction within ...

8. 20(5)-Any person who has been refused registration on the grounds of his failure to satisfy the council as to his good character, may appeal from the council's decision as to his character, to a judge of the Supreme Court at any time within ...

8. 27(2)-The council may direct the registrar to strike the name of the member from the register, if the member does not pay the prescribed annual fee within ...

s. 27(3)-The council may direct the registrar to strike the name of the licensee from the register, if the licensee does not pay the prescribed annual fee within ...

8. 32(2)-Notice in writing by the discipline committee, issued under section $32(1)$, of its intention to make an investigation shall be served on the member or permit holder at least ...

8. 35(1)-When a formal hearing is directed by the council pursuant to a recommendation of the discipline committee under section 34, the discipline committee shall give to the member or permit holder whose conduct is being investigated, at least ...

s. 44(1)-Any person who has been fined or suspended or whose name has been struck from the register may appeal from the order of the council to the Supreme Court at any time within ...

8. 44(2)-Any permit holder may appeal an order fining it or revoking a permit, or a refusal to grant or renew a permit, to the Supreme Court at any time within...

8. 50-A prosecution may be commenced for any offence against this Act within ...

8. 3-An estate tax rebate is payable under this Act only in respect of the estate tax on the estate of a person who satifies the domicile requirements of this section and who has died on or after... .

\section{Limitation Period}

1 month after the making of the order, decision or direction sought to be appealed from, or within such further time as the judge under special circumstances may allow.

30 days after leave to appeal has been obtained.

30 days after notice of the the council's refusal to register him has been served on him in writing.

6 months of the date upon which it becomes due.

2 months of the date upon which it becomes due.

10 days before the date of the investigation.

30 days written notice respecting the time and place at which such hearing will be held and specifying the matters to be investigated.

30 days after service of the order has been effected upon him in the manner, mutatis mutandis, prescribed for service of notice by section 32, subsection (2).

30 days after service of the order has been effected.

2 years from the date of the commission of the offence, but not thereafter.

the first day of April,

1967.
Rebate Act, R.S.A. 1970 , c. 126 
Statute

The Alberta Evidence Act, R.S.A. 1970, c. 127

The Execution

Creditors Act,

R.S.A. 1970, c. 128

\section{Action or Remedy}

8. 9(1)-An estate tax rebate is payable in respect of an estate only upon application therefor to the Administrator made with. in ...

8. 12(1)-An applicant for an estate tax rebate who is aggrieved by a decision of the Administrator affecting the right to a rebate or the amount of rebate payable may appeal to the Supreme Court by originating notice of motion within ...

8. 56(1)-Notice of an intention to give in evidence, as proof of the contents, a writing purporting to be a copy of the original of a written instrument used in business on other transactions, and naming a convenient time and place for the inspection thereof, may be given to the opposing party at least ...

8. 56(2)-The copy of the original may be inspected by the opposing party and shall be accepted into evidence in place of the original without further proof unless the opposing party gives notice of intention to dispute its correctness or genuineness, and to require proof of the original, at the trial or proceeding; such notice to be given within ...

8. 4(6)-A person receiving notice pursuant to section $4(5)$ that the sheriff has been instructed to release or abandon a seizure may require the sheriff to continue the seizure to the extent of the aggregate of the sums payable under all subsisting executions in his hands for which he has been instructed not to release or abandon seizure if he gives the sheriff written instructions to continue the seizure, and furnishes the sheriff with such security as is required by him, within ...

s. 4(7)-The sheriff, on receipt of the in structions referred to in section 4(5) shall not release or abandon the seizure unless he is instructed in writing to do so by all persons who at the time of the receipt of the instructions to release or abandon the seizure had subsisting writs of execution in his hands until the expiration of ...

\section{Limitation Period}

90 days of the date the Minister of National Revenue sends a notice of assessment of the estate tax payable in respect of that estate.

90) days of the date the decision is mailed to him.

10 days before the trial or other proceeding in which the proof is intended to be adduced.

4 days after the time mentioned for the inspection.

10 days after the day upon which the notice is mailed.

the 10 days from the mailing of the notices required to be sent by him pursuant to section 4(6). 


\section{Action or Remedy}

8. 20(1)-Where a claim is not contested pursuant to section 21 , then, upon the application of the claimant and upon his filing proof of due service of the affidavit and notice, the clerk of the District Court shall enter a certificate of judgment in Form $\mathbf{E}$ for the amount of the claim and costs after...

8. 21(3)-Where a debtor contests a claim pursuant to section 21(1) and (2) he shall file his affidavit within ...

8. 21(5)-Notice that the claim is contested, whether by the debtor or by a creditor, together with a copy of the affidavit, if any, shall be served upon the claimant within ...

s. 22(2)-A claimant who has received notice that the claim is contested shall be deemed to have abandoned his claim if he does not apply to a judge to hear and determine the contest within ...

s. 24(c)-Where a claim is contested by a creditor after the execution based on the certificate of judgment has been placed in the sheriff's hands, the sheriff shall, unless the judge otherwise orders, levy the claim as if the claim had not been contested and shall distribute the residue of the money made from the levy among those entitled, as soon as is practicable after the expiry of the period of . .
Limitation Period

(a) 10 days from the date of service if it was made within the Province, or

(b) the time fixed by the order under section 19 subsection (3) if such service was made outside Pro. vince, or

(c) 20 days from the date of such service if it was made in Canada and outside Alberta and no order was made under section 19 subsection (3), or

(d) 25 days from the date of such service if it was made in the United States of America and no order was made under section 19 subsection (3).

(a) 10 days after service upon him of the affidavit of claim and the notice, or

(b) within the time fixed by order of a judge, or

(c) within such further time as a judge may allow.

5 days after the affidavit has been filed or after the order has been made.

10 days after the receipt of the notice or within such further time as the judge may fix by order either before or after the expiration of 10 days.

14 days mentioned in section 23. 
Statute

The Expropriation Procedure Act, R.S.A. 1970 , c. 130

Note: A NEW EX. PROPRIATION ACT WAS PASSED IN THE 1974 SPRING SESSION OF THE LEGISLATURE. Therefore any or all limitation periods should be checked by reference to the new Act.

\section{Action or Remedy}

8. 31(3)-The statement of monies owing under this section is final and conclusive as between all persons and the sheriff, and the sheriff shall make distribution forthwith pursuant to the statement if no objection as provided by this Act is made within ...

8. 31(5)-A person affected by the proposed scheme of distribution may contest it by giving a notice in writing to the sheriff stating his objection to the scheme and the grounds thereof within ...

s. 31(6)-An objection pursuant to section 31(5) shall be deemed to be abandoned unless the person contesting the scheme of distribution applies to a judge for an order adjudicating upon the matter in dispute within ...

8. 47-The provisions of The District Courts Act, The Judicature Act and the Alberta Rules of Court apply to proceedings under this Act except where inconsistent with this Act or any regulations made under this Act.

8. 14(1)-Where land is expropriated under the procedure prescribed by this Part, (Part I-Crown Expropriation) the Minister shall cause notice to be given to any owner with whom he has not been able to reach a settlement within ... .

8. 16(1)-A claim by an owner for com pensation for injurious affection of land is forever barred unless;

(a) the owner files the claim and particulars thereof in the office of the Minister not later than ...

(b) where no public work is to be constructed, such claim shall be filed not later than ...

and if the claim for compensation is not filed within that time the right to compensation is forever barred.

8. 16(2)-The Minister shall serve upon any owner with whom he is not been able to reach a settlement, the offer of a sum in full payment of the compensation for the land injuriously affected within ...

\section{Limitation Period}

10 days after all the copies of the statement have been delivered or posted or within such further time as a judge may allow.

10 days after all the copies of the statement have been delivered or posted or within such further time as a judge may allow.

10 days thereafter.

(Note: check appropriate statutes for Limitation Periods.)

30 days after the registration of the plan or notification.

1 year after the completion or abandonment of the public work; or

1 year after the date of expropriation.

3 months

(a) from the receipt of a claim for compensa. tion in accordance with subsection (1), or

(b) of becoming aware of injurious affection for which the right for compensa. tion is not barred under subsection (1). 
Statute

Part II, Expropriation by Municipal Authorities

\section{Action or Remedy}

8. 16(4)-An owner shall be deemed to be satisfied with and bound to accept the compensation offered pursuant to subsection (2) if he does not notify the Minister in writing of his dissatisfaction within ...

8. 17(1)-The Minister shall serve upon any owner with whom he has not been able to reach a settlement the offer of a sum in full payment of the compensation for the land expropriated within ...

8. 17(3)-An owner shall be deemed to be satisfied with and bound to accept the compensation offered pursuant to subsection (1) if he fails to notify the Minister in writing of his dissatisfaction within ...

8. 19(1)-Where the Minister and an owner agree, pursuant to the provisions of section 18, that the compensation is to be determine by arbitration the Minister shall make a submission to two arbitrators within ...

8. 20(1)-Where the Minister and an owner do not agree that the compensation is to be determined by arbitration, the compen. sation shall be determined by the court and the Minister shall file with the court a statement of particulars within ...

8. 27(1)-A claim for compensation by an owner shall be forever barred unless such owner files a claim and particulars thereof with the clerk or secretary treasurer;

(a) at any time after the completion or abandonment of the works or after the damage is sustained but not later than...

(b) where no work is to be constructed, not later than ...

s. 28 (2)-The municipality shall apply to the Board for an order fixing the compensation to be paid by the municipality for the land expropriated or for the injurious affection, as the case may be,

(a) within ...

\section{Limitation Period}

60 days of the date of service of the offer pursuant to the provisions of section 16(1).

3 months from the date of registration of the plan or notification.

60 days of the date of service of the offer made pursuant to subsection (1).

60 days of the service of the service of the notice pursuant to section 18 .

60 days of the service of the notice pursuant to section 18.

2 months after notice has been given in a new spaper circulating in the municipality of the completion or abandonment of the works; or,

1 year from the date of registration of the ex. propriation by-law and plan of survey, if any, in the land registry.

3 months after the date of registration of the bylaw and the plan of survey, if any, in the land registry, or 
Statute

Part III, Expropriation by Companies

Part IV, Expropriation by other Bodies

Part V, General

Amended by 1972 , c. $918.42(1)(b)$
Action or Remedy

(b) in the case of a claim under section 27 , within ...

8. 30-Where proceedings for the expropriation of land have been commenced or authorized but no entry on or use of the land has been made or authorized except for the purpose of survey, or if an entry has been authorized but has not been acted upon, the council may by by-law adopt the award at any time within ...

8. 39(1)-The company, or the owner of the land expropriated, or their successors or assigns, may apply to the Board that granted the expropriation order for an order terminating the estate or interest of the company where the company has not begun the construction of his works or has discontinued the use of his works or has failed to pay the sums fixed as com. pensation by the order, after the expiration of ...

8. 41-Where an authorizing Act empowers an authorized body to acquire land by expropriation, the land may be expropriated in the same manner, mutatis mutandis, as in the case of an expropriation by a company under Part III of this Act, and compensation therefor shall be determined in the same manner as in the case of a company expropriating land under Part III.

8. 42(4)-Where land entered upon is not expropriated, no action lies against the expropriating authority for damage occasioned by him in the exercise of a power given by this section unless notice in writing signed by the claimant is given to the expropriating authority who exercised the power within ...

8. 48(1)-The provisions of Part 1 of the Public Utilities Board Act apply to proceedings and orders of that Board under this Act insofar as they do not conflict with the provisions of this Act.

8. 53(2)-A party may appeal a Surface Rights Board order under Part 3 pursuant to the provisions of section 53(1) as to the amount of money payable and the person to whom money is payable and that party shall

(a) cause a notice of appeal to be filed in the office of the clerk of the District Court in the judicial district in which the land is situated within ...

\section{Limitation Period}

3 months after the date on which the claim and particulars were filed under that section, and if the municipality fails to so apply the owner may apply at any time thereafter.

60 days of the making of the award.

6 months from the date of an order under this Part.

6 months from the date of an order.

6 months after notice was given to the claimant pursuant to subsection (1).

see Public Utilities Board Act, R.S.A. 1970, c. 130 , s. $50(2)$ and $s$. $62(2)$ and s. $63(2)$ to be read in conjunction with s. 52 of the Expropria. tion Procedures Act.

30 days after the date of the order declaring the amount of money pay. able; and 
Statute

The Family Court

Act R.S.A. 1970, c. 133

The Family Relief Act, R.S.A. 1970, c. 134

The Farm Implement

Act, R.S.A. 1970, c. 136

\section{Action or Remedy}

(b) shall serve the Board and other parties to the order appealed from or their respective solicitors with a copy thereof, by personal service or by registered mail not later than ...

s. $53(4)(b)-$ The clerk of the district court, upon receiving the certified copies of the documents referred to in subsection (3) shall notify the Surface Rights Board and the parties or their respective solicitors of the date of the hearing by registered mail addressed to them at their addresses set out in the notice of appeal within ...

s. 6(1)-A person entitled to alimony or maintenance under a judgment or order of the Supreme Court of Alberta may file a copy of the judgment or order in the Family Court and when so filed it is en. forceable in the same manner as an order made by a magistrate under Part 4 of the Domestic Relations Act.

8. 12-A party to proceedings under this Act who is dissatisfied with an order or refusal to make an order may appeal to the District Court within ... .

8. 16(1)-Subject to subsection (2), no application may be made except within...

8. 18(1)-The executor, administrator or trustee shall not distribute any portion of the estate to any beneficiary without the consent of all of the dependants of the deceased, or unless authorized to do so by order of a judge made on summary application until the expiration of ...

8. 6(1)-A purchaser of a new farm implement which fails to perform the work for which it was intended under reasonable operating conditions and with proper use and maintenance may give notice by registered mail of the failure to perform to the vendor, the dealer and the Minister with. in ...

The dealer or vendor shall provide the purchaser with a satisfactory substitute implement for the purchaser's use until his implement is made to perform in a satisfactory manner within ...

8. 6(1)(a)-Given reasonable operating conditions the dealer or vendor shall endeavor to make the implement perform in a satisfactory manner, not later than the ...

8. $6(1)(b)-$ If reasonable operating conditions do not exist following the receipt of the notice, the dealer or vendor shall endeavor to make the implement perform in a satisfactory manner not later than the...
Limitation Period

10 days after the filing of the notice of appeal.

10 days after the appeal has been set down for hearing.

See Domestic Relations Act, R.S.A. 1970, c. 113 , 8. $27(8)$, s. $27(1)$ 8. $27(12)$.

20 days of the date of the order or refusal.

(See provisions of 8.27 of The Domestic Rela. tions Act relating to appeals.)

6 months from the grant of probate of the will or of administration.

6 months from the grant of probate of the will or administration.

10 days from the date the implement is first used.

48 hours if the dealer or vendor fails to make the implement perform in a satisfactory manner by the end of those 7 days.

7 th day after receiving the notice.

7th day of reasonable operating conditions after receipt of the notice. 
Statute

amended by 1971 c. 33
The Financial

Administration Act, R.S.A. 1970 , c. 142

\section{Action or Remedy}

8. 22(2)-A dealer may personally serve on the vendor, or send by prepaid registered mail to the vendor a written or printed notice to purchase containing a request by the dealer that the vendor purchase all the unused farm implements and all unused parts obtained from the vendor within ...

8. 22(5)-Subject to subsection (6) the amount payable by a vendor for an unused farm implement, attachment or unused part becomes due and owing

(a) on the day that immediately follows the expiry of ...

s. 22(6)(b)-The due date for payment under subsection (5) and the 90 day period referred to in subsection $(10)$ (a)(ii) may be extended by an order of the district court upon the application of the vendor by way of originating notice of motion returnable on a day not later than ...

8. $22(8)(\mathrm{e})-\mathrm{A}$ vendor is not required to purchase any unused farm implement, attached or unused part that has not been adequately prepared for shipment in accordance with subsection $(10)(b)$ within ...

8. $22(10)(a)$-The dealer is responsible for the care and custody of an unused farm implement attached or unused part that has not been adequately prepared for shipment in accordance with subsection (10)(b) within ...

8. $89(2)$-The treasurer shall state an account against that person in the matter to which the notice relates, charging interest from the date of service thereof, where a person fails to pay over, apply or account for any public money or to transmit proper documents within ...

\section{Limitation Period}

90 days after the date an agreement expires or is terminated by the dealer or the vendor for any reason.

90 days after the day the vendor receives the notice to purchase, or

(b) on the 30th day after the day that the vendor removes all the unused farm implements, attachments and unused parts from the possession of the dealer, whichever day first occurs.

120 days after the day on which the vendor received the notice to purchase, if the court is satisfied that the vendor's failure to remove all the unused parts from the possession of the dealer was caused by circumstances beyond the vendor's control or by the fault of the dealer.

the 90-day period referred to in subsection $(10)(a)(i i)$ or any extension thereof under sub. section (6).

(i) the day the vendor removes it from his possession at his place of business, or

(ii) the day following the expiry of 90 days after the day the vendor receives the notice to purchase from the dealer or any extension thereof under subsection (6).

the time limited by the notice served on him. 
Statute

The Firefighters and Policemen Labour Relations Act, R.S.A. 1970 , c. 143
The Fire Prevention Act, R.S.A. 1970, c. 144

\section{Action or Remedy}

8. 6(2)-A notice under subsection (1) requiring collective bargaining shall be at least...

s. $9(1)-W h e r e$ the parties fail to agree on the terms of an agreement during negotiations for a collective agreement, or revision or renewal of an existing agreement, either of them may apply to the Minister for the appointment of a conciliation com. missioner;

(a) where there is no collective agreement in force, not later than ...

(b) where there is a collective agreement in force, not later than ...

8. 9(3)-The decision of the Minister on the application for the appointment of a conciliation commissioner shall be made within ...

8. 10(3)-The conciliation commissioner shall transmit a report to the Minister setting out the matters upon which the parties have agreed, and the matters upon which the parties cannot agree, within ...

s. 12(4)-The Minister, upon the written request of the other party, may appoint a member in lieu thereof where either party;

(a) fails to appoint any member of the board of arbitration as required by subsection (1) within ...

(b) having appointed a person who is unable or unwilling to act, fails to appoint another member of the board of arbitration within ...

s. 12(5)-The Minister, upon notice in writing of the failure given to him by any of the members of the board or by either of the parties, may appoint an additional member to be chairman of the board where the members of the board of arbitration fail to agree upon an additional member within ...

8. 14(1)-After making full inquiry and without undue delay, the board shall make its award in accordance with this subsection and shall transmit the award to the parties and the Minister not more than ...

8. 23(1)-Where an 'owner or occupier deems himself aggrieved by an order made by a person other than the fire com. missioner, then if the order is to remove material, or to remedy conditions, he may appeal to the fire commissioner within ...

\section{Limitation Period}

14 days before the time fixed in the notice for the meeting.

90 days from the date notice to negotiate was served; or

the date of the termination of the agreement.

3 days after the receipt of the application.

14 days, limited by the terms of his appoint. ment or within such longer time as may be agreed to by the parties.

7 days after receipt of the notice to refer the dispute to a board of arbitration; or

7 days after receiving notice of the inability or unwillingness of the member to act.

5 days after the appointment of the member last appointed.

14 days (exclusive of Saturdays, Sundays and other holidays) after the date of appointment of the chairman of the board of arbitration.

48 Hours of the making of the order. 
Statute

The Forest Act, 1971 , c. 37

\section{Action or Remedy}

s. 24(1)-Where the order is to alter, repair, remove or destroy, or to alter the use or occupancy, the person feeling himself aggrieved may appeal to the fire commissioner within ...

s. 24(3)-If the party appealing is dissatisfied with the decision of the fire commissioner he may apply by petition to a judge of the district court having jurisdiction in the judicial district within which the property lies, to review the decision, within ...

8. 24(4)-The party appealing shall file with the clerk a bond in accordance with subclause (b)(i) through (iii) within ...

8. 34-No information or complaint in respect of an offence under this Act shall be made or laid except within . . .

8. 23(3)-Where the Minister is satisfied that any order made by him for the purpose of its reinstatement has been reasonably complied with by the holder, he may reinstate a suspended or cancelled quota or, with the approval of the Lieutenant Governor in Council, a suspended or cancelled forest management agreement, upon application therefor by the holder within ...

s. 23(4)-Where the Minister is satisfied that the order made by him for the purpose of its reinstatement has been reasonably complied with by the holder, he may reinstate a suspended or cancelled timber licence or timber permit upon application therefor by the holder within ...

8. 24-Where in the opinion of the Minister it is in the public interest to do so, he may alter, vary or cancel any provision, condition or area of a quota, licence or permit ...

s. $33(1)$-Where a seizure is made pursuant to section 32, a copy of the notice of seizure shall be served in accordance with the provisions of subclauses (a) through (e) and subsection (2) of section 33 within ...

8. $34(1)-W h e r e$ timber or primary timber products have been seized and notice of seizure has been served, the timber or timber products shall be forfeited to the Crown and may be dealt with at the discretion of the Minister unless a claim to recover it is made within ...

\section{Limitation Period}

10 days of the making of the order.

5 days of the service upon him of a copy of the decision.

5 days of the filing of the petition or within such extended time as the judge may allow.

2 years after the time when the matter of the information or com. plaint arose.

6 months of the date of suspension or cancellation.

60 days of the date of suspension or cancellation.

30 days after serving a notice of his intention to do so by registered mail on the holder of the quota licence or permit.

10 days of the date of seizure.

30 days from the date of the seizure. 
Statute

The Franchises Act, 1971, c. 38

\section{Action or Remedy}

s. 34(2)-Where timber or primary timber product has been seized but no person is in actual or apparent possession or control of the timber or timber products and no notice of seizure has been served, the timber or timber product shall be forfeited to the Crown and may be dealt with at the discretion of the Minister unless a claim to recover it is made within ...

8. 36(1)-Any person claiming to be the owner of timber or primary timber products that have been seized under this Act may, apply by originating notice of motion to a judge of the District Court for an order for their release from seizure and their delivery to him upon at least...

s. 51-A person who has been served by ordinary mail with a notice pursuant to section 50 of a demand of payment of the stated amount of the penalty and the grounds upon which the penalty is assessed shall pay to the Minister the amount of the penalty within ...

s. 6-Where a material adverse change occurs after the date of application for registration of a franchise, an amendment to the application for registration shall be filed with the Commission as soon as practicable and in any event within ...

s. 9-If the Director finds that security for performance of adequate financial arrangements in respect of the franchises necessary and appropriate to protect prospective franchises or sub-franchisors, he may by order require the giving of such security until no later than ...

8. 10(2)-Every determination by the Director pursuant to section $10(1)$ to either accept or reject the prospectus filed with the registrar shall be made in writing within ...

8. 15(1)-A franchisor shall advise in writing, by an application to amend the registration and prospectus, of any material change in the information contained in the application or prospectus as originally submitted, amended or renewed, and the application shall be filed with the Registrar as soon as practicable and in any event within ...

8. 17-The registration of a franchise offering may be renewed for additional periods of one year each by submitting to the Director a registration renewal statement in the prescribed form no later than ...

\section{Limitation Period}

30 days from the date of the seizure of the timber or timber products.

7 days notice to the Minister.

30 days from the date of service of the notice.

10 days from the date the change occurs.

the time of opening by the franchisee of the franchise business.

30 days of the receipt of the application for registration of the pros. pectus and any amending document, and the person who filed the prospectus shall have a prior opportunity to be heard.

10 days from the date the change occurs.

30 business days prior to the expiration of the registration unless such period is waived by the order of the Director. 


\section{Action or Remedy}

8. 20-The registration of a salesman may be renewed for additional periods of one year each by submitting to the Director a registration renewal statement in the prescribed form no later than ...

s. 22-Where the granting of an opportunity to be heard would be prejudicial to the public interest, the Director may suspend any registration of a salesman without giving the salesman an opportunity to be heard in which case he shall forthwith notify the salesman of this sus. pension and of a hearing and review to be held before the Commission within ...

8. 33-No proceedings for a contravention of this Act under 8. 32 shall be commenced more than ...

8. $35(2)-N o$ action shall be commenced to amend registration under 8. 15 after the expiration of ...

8. 48(1)-Any person primarily affected by a direction, decision order or ruling of the Director may request and be entitled to a hearing and review thereof by the Com. mission by sending notice in writing by registered mail to the Registrar within ...

8. 49(2)-An appeal from a decision or order or ruling of the Commission may be appealed to the Appellate Division of the Supreme Court of Alberta by way of notice of motion sent by registered mail to the Registrar within ...

8. 53(2)-Pursuant to section 53(1) the Commission may apply to the Supreme Court of Alberta for an order directing that a person comply with a provision, or for an order restraining the person from violating a provision of the Act, by originating notice of motion which shall be served at least ...

s. 54(2)-Any bonds mentioned in section 12 or section 21 may be cancelled by any person bound thereunder by giving the Registrar at least...

\section{Limitation Period}

30 business days prior to the expiration of the registration unless such period is waived by the order of the Director.

15 days of the date of the suspension, which hearing and review shall be deemed to be a hearing and review under section 48 .

1 year after the facts upon which the pro. ceedings are based first came to the knowledge of the Commission.

2 years from the receipt of the statement of ma. terial facts, prospectus or amended prospectus by the purchaser, or the date of the contract referred to in subsection (1), which ever is the later.

30 days after the mailing of the notice of the direction, decision, order or ruling.

30 days after the mailing of the notice of the order.

2 clear days before the day named in the notice for hearing the application.

3 months notice in writing of intention to cancel and, subject to subsection (3), it shall be deemed to be cancelled on the date stated in the notice, which date shall not be less than 3 months after receipt of the notice by the Registrar. 
Statute

The Freehold Mineral Taxation Act, 1973, c. 89

\section{Action or Remedy}

s. 11(1)-An owner whose name appears on the assessment role may appeal to the Appeal Board to have an assessment roll varied or to have a mineral right included on the assessment roll by giving the Appeal Board and the Deputy Minister written notice on or before ...

8. 11(3)-The Deputy Minister may appeal to the Appeal Board by giving written notice to the Appeal Board and to person shown on the assessment roll as the owner on or before ...

8. 11(4)-If it appears from an appeal or otherwise that any mineral right is assessed in the name of the wrong person as owner, the Deputy Minister

(a) shall appeal by giving notice to the Appeal Board to vary the assessment roll and

(b) shall cause to be sent by mail an assessment notice containing the particulars appearing on the roll with respect to the mineral right assessed and shall cause a copy of the notice of appeal to be sent to the person who is alleged to be wrongfully shown on the assessment roll as owner,

on or before ...

8. 11(6)-A person entitled to appeal under subsection (5) shall give notice in writing of his appeal to the Appeal Board and the Deputy Minister

(a) on or before...

(b) if such notice is sent after April 30th within...

s. 17(1)-There shall be added to the unpaid tax a penalty consisting of a sum equal to $5 \%$ of the unpaid tax where the whole or any part of the tax levied under section 14 remains unpaid ...

8. 19(a)-Where taxes with respect to a mineral right are 30 days in arrears, the Deputy Minister or Superintendent may send notice by registered mail to the owner advising him that his certificate of title may be cancelled unless all taxes and penalties due are paid within ...

\section{Limitation Period}

the next following May 15 th.

the next following May 15 th.

May 15th.

the next following May 15th if the notice prescribed by subsection (4) is sent from the office of the Deputy Minister on or before April 30th or,

15 days from the date on which notice prescribed by subsection (4) is sent from the office of the Deputy Minister.

30 days after the specified date in the notice under section 15.

90 days from the date of the mailing of the notice. 
Statute

The Fuel Oil Tax Act, R.S.A. 1970, c. 153

The Garagemen's Lien Act, R.S.A. 1970 , c. 155

\section{Action or Remedy}

8. 20(6)-The Deputy Minister shall cause to be published in one issue of the Alberta Gazette, a "warning of impending cancellation of title to minerals" unless the taxes have been paid within ...

8. 20(8)-The Deputy Minister shall pay the fee of $\$ 3.00$ for each certificate of title and shall instruct the Registrar to discharge the tax arrears notification in respect of each certificate of title if all taxes and penalties due under this Act together with a fee of $\$ 3.00$ for each certificate of title affected are paid to the Deputy Minister within ...

8. 20(10)-The Deputy Minister or Superintendent may deliver or mail to the Registrar a notice in Form $D$ in the Schedule and upon receipt of any such notice the Registrar shall cancel the certificate of title of the owner with respect to that mineral right notwithstanding any other Act if the taxes and penalties due and owing with respect to the mineral right and fee of $\$ 3.00$ to discharge the tax arrears notification have not been paid at the expiration of ...

8. 20-A prosecution for a contravention of this Act may be commenced within ...

8. $4(1)(a)$ (c)-A lien referred to in 8.3 ceases and determines unless the garageman files a claim of lien in Form $A$ in the schedule in the office of the registration clerk together with an affidavit in Form B verifying the lien on or before...

s. 7(1)-Upon the filing of a claim of lien pursuant to this Act a lien continues for a further period of ....

8. 7(2)-A lien determines upon the expiry of ...

8. 7(3)-Where it appears to a judge on ex parte application made within the 6 months referred to in subsection (2) that a seizure cannot be affected within such 6 month period, he may extend the time for affecting seizure for a further period not exceeding 6 months from the date of his order, in which case, and if a copy of the order is filed in the clerk's office within the 6 months referred to in subsection (2), the lien does not determine until ...

\section{Limitation Period}

60 days after the mailing of a notice to an owner pursuant to section 19.

90 days after the date of mailing of the notice under section 19 .

90 days after the date of the mailing of the notice under section 19.

2 years from the date of the contravention, but not thereafter.

the 21st day that the storage of the vehicle for which a lien is claimed terminated or that the accessories for the motor vehicle were furnished as the case may be.

6 months from date of filing.

6 months from the date of filing thereof unless within the period of 6 months the conditions in section $7(2)(a)$ and (b) are fulfilled.

the 6 month period from the date of the making of the order expires. 
Statute

The Gas Protection Act, R.S.A. 1970, c. 156

The Gas Utilities Act, R.SA. 1970, c. 158

The Hail and Crop Insurance Act, R.S.A. 1970 , c. 164

Amended by 1973 , c. 28

\section{Action or Remedy}

8. 12(4)-A prosecution for a contravention of this Act by a person, municipality or corporation may be brought within ...

s. 29(2)-A new schedule of rates may be put into effect by the owner of the gas utility and upon receiving the approval of the Board thereto unless a complaint is made or an inquiry is directed into the new schedule of rates within ...

8. 53(2)-Leave to appeal a decision of the Gas Utilities Board to the Appellate Division of the Supreme Court of Alberta upon a question of jurisdiction or upon a question of law shall be obtained from a judge of the Appellate Division upon application made within ...

8. 53(5)-The party appealing shall give notice in writing that the case has been set down for hearing, to the parties affected by the appeal or their respective solicitors and to the chairman of the Gas Utilities Board within ...

s. 17(1)-A person who has effected insurance with the hail and crop insurance corporation may make application to the corporation for the cancellation of his insurance in whole or in part not later than...

8. 18(10)-Notwithstanding anything contained in any statute or the common law, no proceedings under subsection (6) or (7) may be commenced except within ...

8. 19(1)-When a crop insured under this Part is damaged by hail, the applicant shall send a notice of claim of loss in such form as may be prescribed by the corporation within ...

s. 19(10)-The claimants shall furnish by statutory declaration or otherwise such proof of the damage as the corporation may require in case of his failure to give the corporation the notice referred to in subsection (1) within ...

8. 19(11)-The corporation shall not pay any claim in respect of any insurance effected by the corporation unless notice of the claim is made before...

8. 20(1)-If the claimant or his agent has not approved the report and recommendation of the adjuster or the corrected report of the corporation, the claimant or his agent may send a notice of appeal to the corporation at Calgary, setting out the reasons for the appeal, within ...

\section{Limitation Period}

2 years of the commission of the alleged offence, but not thereafter.

60 days following the filing of the new schedule with the Board.

1 month after the making of the order or decision, sought to be appealed from, or with. in such further time as the judge, under special circumstances, may allow.

10 days after the appeal has been set down.

the first day of August in the year in which the insurance was effected.

18 months after the date on which the offence complained of is committed.

3 days after the date upon which the damage occurs.

30 days after the occurrence of the damage to which the notice relates.

the sixth day after the date that the policy expires.

5 days of the receipt of such report. 
Statute

The Harvesting Liens Act, R.S.A. 1970 , c. 165
The Alberta Health Care Insurance Act, R.S.A. 1970 , c. 166 Amended by the Health Insurance Statutes Amendment Act, 1972, c. 109

The Health Insurance Premiums Act, R.S.A. 1970 , c. 167

\section{Action or Remedy}

s. 20(2)-The claim referred to in subsection (1) shall be determined by the corporation on the basis of the report made by the adjuster, if the claimant or his agent does not send a notice of appeal within the period of ...

s. 40(10)-Proceedings under section 40(6) or (7) relating to the sale or disposal of crops that are subject to lien by the Alberta Hail and Crop Insurance Association shall be commenced within ...

8. 5(2)-A lien and charge filed in accordance with the provisions of this subsection takes priorities over all other charges, liens, mortgages and encumbrances on crops as referred to in this subsection except as set out in The Crop Liens Priorities Act, upon filing the crop mortgage note, statement and affidavit at time within ...

8. 22.1(7)-A person notified of any re assessment by the Commission may appeal the reassessment to the Supreme Court of Alberta by way of originating notice of motion if the notice of motion is returnable within...

8. 22.2(3)-A copy of an order under this section shall be served on the practitioner against whom it is made, and except in the case where it was made with his consent, the practitioner may apply to the Supreme Court of Alberta by originating notice of motion, to have the order rescinded or varied within ...

s. 17(1)-An amount payable under this Act by a resident to the Commission which has not been paid may be certified by a member of the Commission upon the expiration of ...

8. 17(5)-The Commission may proceed against a person to whom a premium notice is given only by action for the amount owing, and not under this section, where such person has filed with a Commission a notice of objection denying his liability for the premium or disputing the amount of the premium owing within ...

\section{Limitation Period}

5 days mentioned in subsection (1).

1 year from the date on which the offence complained of occurs and not afterwards.

30 days after the date on which the harvesting advances, in respect of which the mortgage note was given, were obtained by the farmer. During this period, the person entitled to the benefit of the crop mortgage note has, for the purpose of securing payment of the amount owing under the note, a first lien and charge upon the grain crops of the above mentioned farmer, which were grown in the year in which the harvesting advances were made, and the proceeds of the grain crop referred to therein.

60 days after the date upon which he was so notified.

30 days after the date on which he received the copy of the order.

30 days after the mailing of a premium notice to the person who is in arrears of premiums at his last known address.

the 30 day period referred to in subsection (1). 
Statute

The Highway

Traffic Act,

R.S.A. 1970,

c. 169

\section{Action or Remedy}

8. 21(2)-A prosecution for an offence under this Act or the regulations may be commenced within...

8. 27(3)-Where the owner of a vehicle who is resident outside Alberta has complied with the laws of his place of residence with respect to the registration and licensing of the vehicle, it may be brought into Alberta for temporary use therein for a period not exceeding ...

8. 31(4)-The registered owner of a commercial or public service vehicle shall deliver to the Minister the certificate of registration of the vehicle not later than...

8. 189(4)-A vehicle stored pursuant to this statute may be disposed of by public auction upon the approval in writing of the sheriff where that vehicle is not claimed in return for full payment of the removal and storage costs actually paid by the registered owner, within ...

8. 200(1)(b)(i)-In any prosecution under this Act, a certificate stating the result of a test of a tuning fork used for determining the accuracy of a radar set shall be admitted in evidence as prima facie proof of the facts stated therein and of the signature of the person signing the certificate provided it bears a date thereon not more than ...

8. $200(1)(b)(i i)-I n$ any prosecution under this Act, a certificate stating the result of the speedometer test of the motor vehicle shall be admitted in evidence as prima facie proof of the facts stated therein provided it bears a date thereon not more than ...

s. 207(4)-A suspension or disqualification arising pursuant to 8.207 term. inates upon the expiration of ...

s. 209(3)-Where a person convicted under 8. 225(3) of the Criminal Code for a second or subsequent time and the convicting judge orders the suspension of a motor vehicle registration, an offence is committed when the license plate and registration certificate are not delivered to the Registrar within ...

s. 238(2)-The Driver Control Board shall not suspend or restrict an operator's licence of a person without giving him at least...

8. 240(1)-Where the Board suspends the operator's licence of a person for an indefinite period or for a period in excess of 6 months, the person may apply, to the Board for a review of the suspension and the Board shall give him an opportunity to be heard within ...

\section{Limitation Period}

2 years from the date of the commission of the offence.

6 months.

the 14th day after the ownership passes.

30 days of its removal.

one year before or after the date of the offence charged.

30 days before or after the offence charged.

24 hours from the time the suspension or disqualification arose.

14 days of the date of the order.

10 days notice in writing.

30 days. 
Statute

The Homeowner's Act, R.S.A. 1970, c. 170

The Homestead Lease Loan Act, R.S.A. 1970, c. 172

The Hospitals Act, R.S.A. 1970 , c. 174

The Hospital Services Commission Act, 1971, c. 45

The Individual Rights Protection Act, 1972, c. 2

\section{Action or Remedy}

s. 240(3)-Any person who considers himself aggrieved by a decision of the Board may appeal the decision of the Board to a judge of the Supreme Court within ...

8. 244(1)-The Minister may suspend an operator's licence of a person who, where a judgment for damages arising out of a motor vehicle accident is rendered against a person, fails to satisfy the judgment within ...

8. 14(4)-A prosecution under section 14(3) may be commenced within ...

8. 14-A loan shall be repaid in full within ...

8. 19(1)-A district board shall send a requisition approved by the Minister for that part of the budget attributed to a municipality to the council of such municipality before ...

8. 19(3)-The Council of an included municipality may apply to the Minister to vary the division of the budget described in the requisition approved by the Minister within ...

8. $32(3)(b)-T h e$ Minister may designate that true copies of the by-laws and amendments shall be sent to him within ...

8. 41(2)-A hospital board has a lien for the cost of services upon the amount of any damages awarded but the lien ceases to be binding after...

8. $43(3)$-The administrator may by registered mail notify the person or council responsible for the removal of the patient to remove such patient from the hospital within ...

8. 17-The Commission shall prepare and present to the Minister its budget for the next ensuing fiscal year before ... .

8. $5(5)(a)$ amended by 1973, c. 61 , s. $9(\mathrm{~b})$ -An action by an employee pursuant to this section to recover the difference between the amount she was paid and the amount to which she is entitled together with costs shall be commenced within ...

8. 17(3)-Any complaint filed pursuant to this section by an aggrieved person must be filed with the Alberta Human Rights Commission within ...

\section{Limitation Period}

30 days after the decision of the Board is sent to his latest address as recorded with the Board.

15 days from the date upon which the judgment became final.

3 years of the commission of the offence but not thereafter.

10 years from the date when an advance is first made to or on behalf of the lessee.

the 30th day of April in each year.

21 days after receipt of the said requisition.

6 months of the date of publication of his order.

10 days following the victim ceasing to be a patient unless the hospital mails a notice of its claim to to injured person.

10 days from the date of receipt of notification.

the 18t day of January each year.

12 months from the date upon which the cause of action arose and not afterward. (Note qualifications to this action contained in $8.5(5)(b)$. (d).)

6 months after the alleged contravention of this Act. 
Statute

The Hydro \& Electric Energy Act, 1971, c. 49

The Improvement Districts Act, R.S.A. 1970, c. 180

The Improvement Districts Stray Animals Act, R.S.A. 1970 , c. 181

\section{Action or Remedy}

s. 21(1)-A board of inquiry established pursuant to section 18 shall submit a report of its inquiry to the Commission within ...

s. 22(2)-The Commission shall deliver all of its files and other records pertaining to the complaint to the Attorney General where it cannot affect a settlement on the course of action to be taken with the person against whom the finding was made within ...

s. 22(3)-The Attorney General may apply to the Supreme Court of Alberta for an order under subsection (5) by way of originating notice of motion filed in the office of the clerk of the Court of the judicial district in which the inquiry of the board of inquiry was held within ...

8. 23(4)-A person may appeal from the finding of a board of inquiry to the $\mathrm{Su}$ preme Court by way of originating notice of motion, which shall be filed with the clerk of the court within ...

the notice of motion shall be returnable on a date not later than ...

8. 33(2)(a)-A Board shall not cancel or suspend an approval, permit or licence under this section until it has given the holder...

s. 38-Every information or complaint for the prosecution of an offence under this Act shall be laid or made within ...

8. 10(5)-The Deputy Minister or any person appointed by him may levy a tax with costs by distress, imposed by an order of the Minister pursuant to this section where it remains unpaid for a period of ...

s. 20(1)-A pound keeper shall post notices of sale at three conspicuous places within the pound district if the known owner of an impounded animal does not redeem it within...

8. 27(2)-By furnishing proof of ownership and by reimbursing the purchaser by the amount paid, together with a bonus of $10 \%$ of the purchase price, the owner of any animal other than a horse may recover the animal from the purchaser within ...

s. 28(3)-Any monies forwarded to the Minister from the sale of the animal shall be paid to the owner of the animal upon application being made to the Minister by the owner of the animal within ...

\section{Limitation Period}

14 days, exclusive of Saturdays and holidays, after its appointment or within such longer period as the Minister may approve.

30 days of the date he was furnished with a copy of the report of the board of inquiry.

30 days after receiving the Commission's files and other records pursuant to subsection (2).

30 days of the date the appellant was furnished with a copy of the report of the board of inquiry and,

15 days after the date it is filed with the clerk.

30 days' notice to rectify his default.

18 months from the time when the subject matter of the proceedings arose. and not afterward.

30 days after the cessa. tion of the drilling or servicing operation.

3 days after the delivering of the notice of im. poundment or within 10 days after the mailing of the notice of im. poundment.

30 days from the date of the sale.

2 years from the date of the sale. 
Statute

The Income Tax Act, R.S.A. 1970, c. 182
The Industrial Wages Security Act, R.S.A. 1970, c. 184

\section{Action or Remedy}

8. 30(3)-The owner of an impounded animal may appeal against the impounding by filing an information and complaint with a justice within ...

8. 36(1)-An appeal from the order of the justice to a judge of the district court may be made within ...

8. 40-A person finding an estray on his premises shall notify the owner immediately either in person or by mail and the estray shall be removed by its owner from the premises within ...

8. 42(5)-No claim for the proceeds is permitted by the owner of an animal sold by the Department under this Act after...

s. 44(1)-Complaints that a person owns a dog that has caused damage to animals outside its owner's property must be made within ...

8. 16(1)-A taxpayer shall pay to the Pro. vincial Treasurer any part of the assessed tax, interest and penalties remaining unpaid, within ...

8. 22(1)-A taxpayer who objects to an assessment may serve the Provincial Treasurer with a notice of objection within ...

8. 23(1)-A taxpayer who has served a notice of objection to an assessment may appeal to the court to have the assessment vacated or varied after the Provincial Treasurer has confirmed the assessment or after...

8. 24(1)-The Provincial Treasurer shall serve on the appellant and file in the court a reply to the notice of appeal within ...

8. 35(2)-Property seized under this section shall be sold by public auction if the owner does not pay the amount due together with the costs and charges within ...

8. 50(3)-An information or complaint in respect of an offence under this Act may be laid or made on or before a day ...

s. 6-Additional security shall be paid to the Minister within ...

\section{Limitation Period}

10 days after giving notice to the poundkeeper.

30 days of the making of an order.

3 days of so being notified, if the owner was notified in person or within 10 days from the date the notice was mailed, if the owner was notified by mail.

2 years of the receipt of proceeds by the Department.

1 month of such act by the dog.

30 days from the day of mailing of notice of assessment.

90 days of mailing of the notice of assessment.

180 days have elapsed after service of the notice of objection and the Provincial Treasurer has not notified the tax payer that he has va. cated or confirmed the assessment.

60 days from the day the notice of appeal is received or within such further time as the court may allow.

10 days.

5 years from the time when the matter of the information or com. plaint arose or within 1 year from the day on which evidence sufficient to justify a prosecution for the offence, came to the Provincial Treasurer's knowledge.

30 days of the mailing of a demand by the Minister. 
Statute

The Infants Act, R.S.A. 1970 , c. 185

The Insurance Act, R.S.A. 1970 , c. 187

\section{Action or Remedy}

s. 8(5)-Exemptions from liability for security payments may be cancelled by the Minister, and the resulting security pay. ments due are to be paid within ...

8. 16(1)-Where an action is maintainable on behalf of an infant in respect of an injury to the infant and the guardian, parent or next friend agreed on a settlement of the claim or action with the person against whom the claim was brought, the guardian of the person against whom the claim is brought may apply for an order confirming the settlement upon giving ...

s. 23(3)-A notice of intention to appeal by an insurer from a ruling of the Superin. tendent as to the admissibility of assets, amounts ruled as liabilities, or to alterations to or corrections of statements must be served on the Superintendent within ...

s. 23(3)-An appeal must be filed with the Lieutenant Governor in Council within ...

8. 47(2)-A licence may be revived and the insurer may again transact business where an undisputed claim or final judgment against the insurer is paid and satisfied within ...

8. 64(2)-A licence may, if void under subsection (1), clause (b), be renewed and the insured may again transact business if an undisputed claim or final judgment is paid and satisfied within ...

8. 72(1)-The applicant for administration of the deposit shall serve the originating notice of motion at least...

8. 81(2)-An appeal from any decision by the receiver appointed under the Act to administer the insurer's deposit may be made within ...

s. 114(2)-The society, branch or lodge shall sell any real estate referred to in this subsection within ...

8. 124(2)-Prima facie proof that a premium has been applied for a purpose other than paying it over to the insurer is present if the agent or broker fails to pay the premium to the insurer within ...

s. 138(18)-Notice of the company's annual meeting shall be given at least ...

8. 156-Notice of the time and place for holding the general meeting of the com. pany shall be given at least...

8. 166(4)-A person who becomes an insider of a public insurance company shall file with the Commission a report of his beneficial ownership of or control or direction over capital securities of the company within...

\section{Limitation Period}

30 days of the mailing of the order of the Minister.

10 days' notice to the opposite party and to the Public Trustee.

15 days of the notice of the ruling.

15 days after service on the Superintendent.

6 months after the notice to the Superintendent of failure to pay the claim or judgment.

6 months after the notice to the Superintendent of failure to pay the claim or judgment.

10 days prior to the date specified in the notice for the making of the application.

30 days of receiving notice of the decision.

7 years after it has been acquired.

30 days after written demand.

15 days before it takes place.

10 days prior to the meeting.

10 days after the end of the month in which he becomes an insider. 
Limitation Period

10 days after the end of the month in which he acquired such beneficial ownership or control. capital securities of the company but who, at a later date acquires such beneficial ownership or control, shall file with the Commission a report within ...

8. 166(15)-An action to enforce any right created by section $166(14)$ relating to disclosure of information by an insider may be commenced only within ...

s. 190(1)-A liquidator shall file with the court and the Superintendent details of schedules within ...

8. 200(1)-Every insurer shall furnish to the insured forms upon which to make the proof of loss required under the contract immediately upon receipt of a request and in any event not later than ...

8. 201-No action lies for the recovery of money payable under a contract of insurance until the expiration of . . .

8. 216(2)-Every insurer that issues or proposes to issue life insurance policies under which all or part of its liabilities and the reserves to be included in its annual statement vary in amount depending upon the market value of a specified group of assets shall file with the Superintendent the form of the policy, the form of the application for the policy, the form or of all endorsements and riders to be used in connection with the policy, and all advertising material to be used at least ...

s. 239(2)-Where a premium is not paid at the time it is due, the premium may be paid within a period of grace of ...

8. 242-Where an insurer fails to disclose or misrepresents a fact material to the insurance, the contract is voidable by the insured, but in the absence of fraud the contract is not voidable after it has been in effect for ...

8. 243(3)-Where a contract limits the insurable age and the correct age of the person whose life is insured exceeds the age so limited, the contract is voidable by the insurer within ...

8. 261-Where an insurer receives sufficient evidence of proof of loss it shall pay the insurance money to the person entitled within ...
2 years after the date of completion of the transaction that gave rise to the cause of action.

7 days after the close of each period of 3 months and until the affairs of the insurer are wound up.

60 days after receipt of notice of loss.

60 days after proof of the loss.

30 days before offering to undertake any insurance of that kind.

30 days, or in the case of an industrial contract, 28 days from the day on which the premium is due.

2 years.

60 days after it discovers the error.

30 days after receiving the evidence. 
Statute

\section{Action or Remedy}

s. 264(1)-An action or proceedings against an insurer for the recovery of in. surance money shall not be commenced more than ...

8. 264(2)-Where a declaration has been made under section 267, an action or proceeding shall not be commenced more than ...

8. 266-An application to the court for a declaration by the court as to sufficiency of proof may be brought upon at least ...

8. 267-An application may be brought for a declaration of a presumption of death upon at least...

8. 272-The insurer may apply to the court ex parte for an order for payment of money into court at any time after...

s. 274(2)-An order for commutation of instalments of insurance money may be granted by the court upon the application of a beneficiary and upon at least...

8. 276-The court may order that insurance money or any part thereof be paid into court where an insured does not pay the money to some person competent to receive it or into court within ...

8. 308(1)-Every insured against whom an action is commenced for damages occasioned by an automobile shall give notice thereof in writing to the insurer within ...

8. 308(2)-Every insured against whom an action is commenced for damages occa. sioned by an automobile shall disclose to a judgment creditor entitled to the benefit of any motor vehicle liability policy particulars of such contract within ...

s. 314-An owner or insurer is guilty of an offence if he does not comply with a demand for particulars of insurance within ...

s. 317-Every action or proceeding against an insurer under a contract in respect of insurance provided under sections 311 , 312 or 313 shall be commenced within the limitation period specified in the contract, but in no event shall the limitation period be less than ...

\section{Limitation Period}

1 year after the furnishing of the evidence required by section 261 or more than 6 years after the happening of the event upon which the insurance money becomes payable.

1 year after the date of the declaration.

30 days notice.

30 days notice.

30 days from the date of the happening of the event upon which the insurance money becomes payable.

10 days' notice.

30 days after receipt of the evidence required by section 261 .

5 days after service of every notice or process in the action.

10 days after written demand therefor.

10 days after receiving a demand.

1 year after the happening of the accident. 
Statute

The Insurance

Corporations Tax Act, R.S.A. 1970, c. 188

\section{Action or Remedy}

s. $333(1)-W h e r e$ a policy evidencing a contract or a certificate evidencing the renewal of a contract is delivered to the insured and the premium or renewal premium has not been paid the contract may be terminated for the non-payment of the premium by the insurer upon ...

s. 351(1)-Where an insurer admits lia. bility for insurance money payable to a minor and there is no person capable of giving a valid discharge the insurer may pay the money into court at any time after...

8. $367(1)$-A person claiming under a contract of livestock insurance shall furnish notice of the claim to the insurer with. in ...

8. 404(1)-A contract of insurance in respect of which an assessment has been made is null and void if the assessment is not paid within ...

s. 406-The company may sue and recover the assessment if a member who is given a premium note refuses or neglects to pay the assessment for...

s. 408-The premium note given for the insurance policy shall on application be given up to the grantor if all assessments levied have been paid ...

s. $419(\mathrm{~b})$-Every fraternal society shall file in the office of the Superintendent duly certified copies of every amendment, revision or consolidation of such articles or provisions of the constitution within ...

8. 420-The Superintendent may take exception to any amendment or revision with. in ...

8. 491-No person whose certificate has been revoked is entitled to a new certificate for ...

s. 499(3)-An insurance broker shall submit to the Superintendent a statement setting out the name of the insured, the nature of the insurance, the full names of the unlicensed insurers, and the amount of insurance placed with each within ...

s. 519-Notice of the insurer's intention to apply for sanction and confirmation of an amalgamation, transfer, reinsurance or purchase shall be given in The Alberta Gazette at least ...

8. 6-The Provincial Secretary may require statement under oath from the officers of the company to enable him to determine the correctness of any return under the Act, and he may require the filing of a further statement under oath within...

\section{Limitation Period}

10 days notice of termination given in writing to the insured.

30 days from the date of the happening of the event upon which the insurance money becomes payable.

10 days after loss.

30 days after the date of payment mentioned in the notice.

30 days after the assess. ment becomes payable.

40 days after the expiration of the term of insurance.

30 days after the passing or adoption of the amendment, revision or consolidation.

30 days after the date of the filing.

1 year after the revocation.

10 days after the placing of such insurance with unlicensed insurers.

30 days before the application is made.

30 days. 
Statute

The Investment Contracts Act, R.S.A. 1970, c. 191

The Irrigation Act, R.S.A. 1970 , c. 192

\section{Action or Remedy}

s. 12(1)-Every registered issuer shall notify the Superintendent in writing of any change in its address for service, any change in its executive officers, and the commencement and termination of the employment, appointment or authorization of each of its salesmen within ...

s. 15-Any person or company upon whom a notice is served under section 14 of this Act or who is affected by any direction, decision, order or ruling of the Commission may request a hearing and review of the direction, decision, order or ruling, by notice in writing served upon the registrar within ...

8. 21(1)-Every appeal to the Supreme Court shall be by way of notice of motion served on the registrar within ...

8. 27(1)-Every registered issuer shall file with the Commission a balance sheet and profit and loss statement for the completed fiscal year, not later than ...

s. 10(1)-Where a petition is made to the Council under this Part, the petition shall be accompanied by proof that the petitioners have published in a newspaper in the district a notice in the prescribed form at least ...

s. 11-Where the Council directs that a hearing is to be held with respect to the petition, the Council shall notify the petitioners and the Board of the hearing at least ...

8. 34(2)-Where the Board demands the resignation of the Director and the Director concerned does not resign the Board shall make an application to the Supreme Court within ...

s. 102-Any complaints regarding the conduct of the elections held in formation of districts or election of trustees must be made within ...

8. 103(1)-Allegations as to irregularities in the election are to be submitted to the Council within ...

8. 117(6)-An assessment notice shall contain a statement of the last day upon which complaints against the assessment may be filed with the district manager, which shall be at least...

s. 121(3)-A notice of hearing of complaints regarding the assessment roll shall be sent to the complainant at least ...

8. 129(1)-Any person to whom a notice of the decision of the court of revision was given under section 126 may appeal to the Alberta Assessment Appeal Board by filing a notice of appeal with them within...

\section{Limitation Period}

5 days of the event mentioned happening.

30 days after the mailing of the notice.

30 days after the mailing of the notice under sec. tion 20 of this Act.

90 days after the expiration of the fiscal year.

21 days prior to the date the petition is submitted to the Council.

10 days prior to that date.

30 days of the date on which the resolution calling for his resigna. tion was passed.

5 days after the trans. mission of the results of the election to the Council.

2 weeks after the election.

30 days from the mailing of the assessment notice.

10 days before the date fixed for the hearing of the complaint.

30 days after the giving of the notice of the decision of the court of revision to that person. 
Staturte

The Judicature Act, R.S.A. 1970 , c. 193

An Act to amend the Judicature Act, 1971, c. 55

The Jury Act, R.S.A. 1970, c. 194

The Alberta Labour Act, 1973, c. 33

\section{Action or Remedy}

8. 148(1)-An action for arrears lies if a person fails to pay the amounts shown in the collector's roll to be owing by him within ...

8. 149(1)-An amount in arrears may be recovered by distress upon any goods and chattels if a person fails to pay the amount shown by the collector's roll to be owing by him within ...

8. 154(1)-A notice of the time and place fixed for hearing the application for confirmation of the enforcement return shall be sent at least ...

s. 172(1)-Any person may make a claim against a board for compensation for water seepage damage if, among other requirements, he files a written notice of his claim at the office of the board not later than ...

8. 172(6)-The board shall refer the claim to the Public Utilities Board if the claim is not settled before...

8. 181(2)-Except as provided in section 172 or 173 , no action or proceeding shall be brought against a board for compensation under section 181(1) unless a notice of writing of the claim for compen. sation has been served upon the district manager within ...

8. 12(1)-Where a judge of the Court has resigned his office, and a case that has been fully heard by the judge, either alone or jointly with another judge or judges, stands for judgment, he may give judgment therein as if he were still a judge of the Court within ...

8. 19(4)-Where a mortgagee or vendor is required by a notice from the mortgagor or purchaser to furnish the mortgagor or purchaser with a statement in writing with respect to the breach of any covenant or the amount owing, then he shall answer that notice within ...

8. 14(2)-A party desiring a special jury may apply therefor if the application is made at least...

8. 35-No juror is liable to a penalty for non-attendance on a special jury unless the summons requiring him to attend is duly served at least ...

8. 15(3)-Employee records required to be maintained by this statute shall be preserved and retained by the employer for a period of at least ...

\section{Limitation Period}

30 days from the delivering or mailing of a billing notice to him.

30 days from the de livering or mailing of a billing notice to him.

20 clear days before the time fixed for the hearing.

the first day of Novem. ber in the year in which the seepage damage occurred.

the next succeeding first day of January or before the expiration of 90 days from the day the notice of the claim was delivered.

6 months of the date that death, injury, loss or damage first occurred.

6 weeks after his resignation.

15 days after he receives it.

8 days before the first day of the sittings at which the case is to be tried.

4 days before the day on which he is required to attend.

3 years from the time each record was made. 
Statute

\section{Action or Remedy}

s. 46-A prosecution for an offence may be commenced within ...

8. 51(3)-A decision, order, directive, de claration, ruling or proceeding of the Board may be questioned or reviewed in an application filed with the court and served on the Board no later than ...

s. 55(3)-Any changes to the information supplied by the trade union to the Board pursuant to subsection (1), clauses (c) and (d) shall be sent to the Board within ...

s. 67-Unless the Board otherwise consents, no trade union shall apply to the Board to be certified as a bargaining agent until at least ...

8. 68(2)-An application by a trade union to be certified as the bargaining agent of employees in a unit may be made

(b) where no collective agreement is in force and a bargaining agent has been certified in respect of any of the em. ployees in the unit, at any time after the expiration of ...

(c) where the certification of a bargaining agent in respect of any of the employees in the unit is questioned or reviewed by the Court at any time after the expiration of ...

(d) where a collective agreement for a term of two years or less is in force in respect of any of the employees in the unit, at any time in the...

(e) where a collective agreement for a term of more than 2 years is in force, at any time...

8. 76(2)-An application for revocation of certification may be made

(a) where no collective agreement is in force at any time after the expiration of ...

(b) where the certification of a bargaining agent is questioned or reviewed by the Court, at any time after the expiration of ...

(c) where a collective agreement for a term of 2 years or less is in force, at any time in the ...

(d) where a collective agreement for a term of more than 2 years is in force, at any time...

\section{Limitation Period}

12 months from the date the alleged offence oc. curred.

30 days after the issue of the Board's decision.

30 days of the date the change is made.

60 days after the date it has complied with section $55(1)(a)(i)$ or (ii).

10 months from the date of the certification of the bargaining agent;

10 months from the date of the final disposition of the question or review;

2 months prior to the end of the term of the collective agreement;

in the eleventh or twelfth month of the second or any subsequent year of the term, or in the two months prior to the end of the term.

10 months from the date of certification of the bargaining agent;

10 months from the date of the final disposition of the question or review;

2 months prior to the end of the term of the collective agreement;

in the 11th or 12th month of the 2nd or any subsequent year of the term, or in the 2 months prior to the end of the term. 
Statute

8. 81(1)-Where any of the applications named in this section have been made and have been refused by the Board, the applicant shall not, without the consent of the Board, make the same or substantially the same application until after the expiration of ...

s. 82(2)-Unless the Board otherwise consents, no employers' organization shall apply to the Board to become a registered employers' organization until at least ...

8. 94(2)-Where a collective agreement is in effect, either party to the collective agreement may by notice in writing require the other party to the collective agreement to commence collective bargaining not less than ...

8. 94(5)-Where a notice to commence collective bargaining has been served, the bargaining agent and the employer or employers' organization shall commence to bargain collectively in good faith without delay but in any event within ...

8. 104(2)-The Minister shall decide whether or not to appoint a conciliation commissioner within...

8. 108-The conciliation commissioner may make a proposal where he is unable to effect a settlement of the dispute within ...

s. 109(1)-Where the Minister accepts the proposal of the conciliation commis. sioner he shall notify the employer and the bargaining agent in writing and require each of them to appoint a person to act as a member of the conciliation board with. in ...

s. 117(1)-The conciliation board shall make recommendations with respect to each matter in dispute and send them to the Minister where a conciliation board is unable to effect a settlement within...

\section{Limitation Period}

2 months prior to the end of the term of the collective agreement;

in the 11th or 12 th month of the second or any subsequent year of the term, or in the 2 months prior to the end of the term.

3 months from the date the previous application was made to the Board.

60 days after the date the employers' organization has complied with section 62(1)(a).

30 days and not more than 90 days preceding the expiry of the term of the collective agreement. (or within such longer period as may be provided for in the collective agreement).

20 days after notice is given.

5 days of receipt of a request to do 80 .

20 days of the date of his appointment or such longer period as is agreed between the parties.

10 days.

20 days of the date the conciliation board is established, or such longer time as may be agreed between the parties. 
Statute

The Land Surface Conservation and Reclamation Act, 1973 , c. 34

The Land Surveyors Act, R.S.A. 1970, c. 197

\section{Action or Remedy}

s. 127(3)-The bargaining agent may make a settlement with one or more of the employers where a strike commences affecting employers on whose behalf a registered employers' organization bargains collectively ...

8. 128(3)-An employer may make a settlement with the bargaining agent where a lockout commences affecting employers on whose behalf a registered employers' organization bargains collectively ...

8. 130-The right to commence a strike or lockout permitted pursuant to section 126 of this statute lasts for ...

s. 136(1)-Where the Minister receives a report from the conciliation commissioner that he is unable to effect a settlement of the dispute he shall serve a notice on the parties to the dispute requiring each of them to appoint a person to act as a member of a collective bargaining arbitration board within ...

s. 9(3)-Where the Minister makes a stop order he shall cause a copy of it to be served on the person to whom it is directed within ...

s. 55(1)-An inquiry shall be held to review a reclamation certificate where a review is requested by the owner or occupant or an operator within ...

8. 56(2)-A person desiring to appeal to the court re: expenses shall file a notice of appeal with the clerk of the district court within ...

8. 56(5)-The appellant shall serve a copy of the notice of appeal on the secretary within ...

8. 57(2)-An operator to whom a reclama. tion order is issued may appeal the issue of the order to the district court by filing a notice of appeal with the clerk before the expiration of ...

8. 57(5)-The appellant shall serve a copy of the notice of appeal on the secretary within ...

8. 13(1)-A member of the Association may dispute the validity of an election by petition to the Supreme Court filed within...

s. 44(2)-The discipline committee who are enquiring into a charge against a member shall serve a notice of the date, time and place of the meeting on the member charged at least ...

8. 50(1)-A member who has been found guilty of conduct unbecoming an Alberta land surveyor may appeal to the Supreme Court within ...

\section{Limitation Period}

60 days after the date of the commencement of the strike.

60 days after the commencement of the lockout.

1 year from the date the right arises.

10 days.

48 hours after the making of the stop order.

30 days of the issue of the certificate.

30 days of the date of mailing to him of the invoice for expenses paid.

10 days of filing.

30 days from the date of the mailing or delivery of the order to the operator.

20 days of filing.

30 days of the date of the election.

10 days before the appointed date.

30 days of the date that the member was served with a copy of the council's findings. 
Statute

The Land Titles

Act, R.S.A. 1970, c. 198

The Landlord \& Tenant Act, R.S.A. 1970 , c. 200

The Landmen Licensing Act, R.S.A. 1970 , c. 202

\section{Action or Remedy}

s. 44-The judge if satisfied with the applicant's title shall make an order di. recting the Registrar to register it after the expiration of ...

s. $73(2)-$ Where there has been registration of a judgment quieting title, the Registrar shall make upon the certificate of title in the register a memorandum cancelling the certificate of title, either wholly or partially according to the tenor of the judgment at the expiration of ...

s. 128(3)-Unless before the expiration of 6 years a renewal of the writ of execution is registered with the Registrar, every writ or renewal ceases to bind or affect the land at the expiration of ...

s. 132-Transfer of land sold by the sheriff under process of law shall be registered, to be valid, within ...

8. 144(1)-Except as otherwise provided in this section, every caveat lodged against any land, mortgage or encumbrance shall be deemed to have lapsed after the expiration of . . .

s. 171-No action shall be brought against the Registrar under sections 165 and 168 unless notice in writing of the intended action has been served upon the Registrar and the Attorney General ...

s. 175-An action against the Registrar for damages under this Act is to be brought within ...

8. 10(2)-Where a landlord applies by originating notice of motion to the Supreme Court for an order for possession the originating notice shall be served at least ...

s. 19(1)-Where a landlord holds a security deposit, then, upon the expiry or termination of the tenancy, he shall return the security deposit to the tenant within ...

or

if all or part of the security deposit may be deducted in accordance with the conditions agreed to by the tenant, the landlord shall deliver a statement of account and return the balance of the deposit, if any, to the tenant within ...

8. 20-The landlord shall not exercise a right to enter the rented premises, except in cases of emergency, unless he has first given written notice to the tenant at least...

s. 9-Where any person is aggrieved by a landman with respect to negotiations where the acquisition of an interest in land or advice given respecting negotiations or acquisitions, the person may file a complaint with the Registrar within ...

\section{Limitation Period}

4 weeks from the date thereof.

3 months after the filing of the judgment.

6 years from the date of its receipt by the Regis. trar.

2 months of the order confirming the sale.

60 days after the notice has been served on the caveator.

3 months previously.

6 years of the cause of action arising.

3 days before the day named in the notice for hearing of the applica. tion.

10 days after the tenant delivers up possession of the premises,

10 days after the tenant delivers up possession of the premises.

24 hours before the time of entry.

60 days of the date of the cause of his grievance. 
Statute

The Legal Profession Act, R.S.A. 1970, c. 203

Amended by 1972 , c. 114

\section{Action or Remedy}

8. 13-The Registrar shall dismiss the complaint if the complainant does not file a request for hearing within ...

s. 16(2)-The chairman of the investigation committee shall hold a hearing within ...

8. 19(4)-The Minister may direct the Provincial Treasurer to pay out of the General Revenue Fund the costs to which each person is entitled where the party responsible for payment of costs fails to make payment within ...

s. 21-Either party aggrieved by a decision of the committee or of the chairman may appeal to the Trial Division of the Supreme Court of Alberta within ...

8. 27-A prosecution under this Act may be commenced within ...

8. 15(1)-A member may dispute the validity of an election of Benchers or the validity of the election of one or more of them by petition to the Supreme Court filed within ...

8. 43(3)-An appeal lies to the Appellate Division from direction of the Benchers made pursuant to this section, and in any such appeal the provisions of $8.70(2)$ and (3) shall apply to the effect that an appeal shall be commenced within ...

8. 70(2)-An appeal by a member found guilty of conduct unbecoming a barrister and solicitor may be made to the Appellate Division of the Supreme Court by the filing of a notice of appeal and by serving a copy of the notice of appeal upon the Secretary both within ...

8. 75(3)-No order for the reinstatement of the member by the Benchers shall be made under section 75 within...

\section{Limitation Period}

14 days from the date of service on him of a copy of the landman's reply.

30 days after receipt by him of the documents referred to in section 14 .

15 days after the chairman's decision is served upon him.

60 days of the date on which the decision is served upon him.

2 years from the date on which the offence is alleged to have been committed, but not thereafter.

10 days from the publication in the Gazette of the notice referred to in section 14.

30 days from the date on which the finding and the order of punishment, if any, is made by the Benchers.

30 days from the date on which the finding and the order of punishment, if any, is made by the Benchers, subject to subsection (3) whereby the President or Vice-President may extend the time for filing or service under subsection (2).

1 year after the date on which the person's name was struck off the roll or on which the person's articles were termin. ated, or, where an order was granted under section 70(4) staying the imposition of a punishment imposed by the Benchers and the punishment is later confirmed by the Court under section 72 , the date on which the Court made its order confirming the punishment. 
Statute

The Legislative

Assembly Act,

R.S.A. 1970, c. 204

The Licensing of

Trades and Businesses

Amendment Act, 1973 , c. 74

The Lightning Rod

Act, R.S.A. 1970,

c. 208

The Limitation of Actions Act, R.S.A. 1970 , c. 209

\section{Action or Remedy}

8. 81(4)-An order made pursuant to $\mathrm{s}$. 81 (1) for the seizure of a member's property and it being placed in the custody of the Secretary, may be varied or set aside on ...

s. 83(3)-A member whose property has been placed in the custody of a custodian pursuant to section 82 , may claim to be entitled to $a$ solicitor's lien upon or in respect of any part or parts thereof if he files a notice of his claim for lien with the custodian within ...

8. 95(2)-A prosecution under this section may be commenced within...

s. 22(a)-A judge of the Supreme Court may permit a petition to be filed or permit proceedings to continue upon any petition that has been filed where a person entitled to vote at an election applies within ...

s. 11.1-A prosecution for a contravention of this Act or any regulation or order passed pursuant to this Act may be commenced within ...

8. 4(d)(ii)-A person licensed pursuant to this section for the sale of lightning rods shall repair damage within a reasonable time if a claim for damage is made with. in ...

8. 10(3)-A prosecution for an offence under this Act or the regulations must be commenced within ...

s. 12-A person claiming against the person who issues a guarantee of installation for installation in contravention of the Act or the regulations must bring action for recovery of the amount of the loss within...

s. 5(1)(a)-Actions for penalties imposed by a statute brought by an informer or by a person authorized to sue for the same, not being the person aggrieved must be brought within ...

8. 5(1)(b)-Actions for penalties given by a statute to the Crown, to the person aggrieved or partly to one and partly to the other, shall be brought within ...

s. 5(1)(c)-Actions for the recovery of money other than a debt charged on land or for an account or for not accounting must be brought within ...

8. 5(1)(d)-Actions grounded on fraudulent misrepresentation must be brought with. in ...

8. 5(1)(f)-Action on a judgment or order for the payment of money must be brought within...

\section{Limitation Period}

2 days notice.

30 days from the service of the order upon him.

2 years after the commission of the offence, but not thereafter.

10 days after the Clerk of the Court has received notice of a disclaimer.

3 years after the contravention but not thereafter.

30 days of the occurrence of the damage.

2 years of the commission of the offence, but not thereafter.

6 months after the occurrence of the loss.

1 year after the cause of action arose.

2 years after the cause of action arose.

6 years after the cause of action arose.

6 years from the discovery of the fraud.

10 years after the cause of action thereon arose. 


\section{Action or Remedy}

s. $5(1)(\mathrm{g})$-Proceedings must be commenced for any other action not in this Act nor in any other acts specifically provided for within ...

8. 5(3)-An action to recover a claim against the estate of a deceased person must be commenced within the longer of ...

8. 8-A person under a disability at the time the cause of action arises may bring an action under 8. 5(1), (c) to (i) within ...

s. 9(1)-An action to recover money where the debtor has promised to pay, acknowledged the debt or made part payment may be brought within ...

8. 14(1)-Proceedings to recover money charged on land, a legacy, or the personal estate of an intestate possessed by his personal representative must be commenced within ...

8. 14(2)-But where there has been a part payment or written acknowledgement an action shall be brought within ...

8. 15(1)-Proceedings to recover arrears of rent must be commenced within ...

8. 15(2)-Where there has been part payment or written acknowledgement, proceedings may be commenced within ...

8. 18-Proceedings to recover land shall be commenced within ...

s. 24-A person becoming entitled in possession to a future estate or interest where such future estate or interest was expectant and where the person last entitled to such estate was not in possession of the land or in receipt of the profits thereof at the time when his interest determined, must bring an action within...

\section{limitation Period}

6 years after the cause of action therein arose.

(a) 2 years from the date of death, or

(b) the time otherwise limited for the bringing of the action.

2 years after he first ceased to be under disability.

6 years after the date of the promise, acknowledgement or part pay. ment, notwithstanding that the action would otherwise be barred under the provisions of this Act.

6 years next after the present right to recover the same accrued to a person capable of giving a discharge therefor or a release thereof.

6 years after the payment or acknowledgement, or the last of such payments or acknowledgements, if more than one was made or given.

6 years after a present right to recover the same accrues to the person capable of giving a dis. charge therefor or a release thereof.

6 years after the payment or acknowledgement, or the last of the payments or acknowledgements if more than one, was made or given.

10 years after the right to recover first accrued to such person, or if the right to recover first accrued to a predecessor in title, then within 10 years next after the right accrued to such predecessor.

(a) 10 years next after the right to take proceedings first accrued to the person whose interest has determined, 


\section{Limitation Period}

or (b) within ...

8. 33(1)-When a mortgagee or a person claiming through a mortgagee has obtained possession of any property, real or personal, comprised in a mortgage or is in receipt of the profits of any land therein comprised, an action to redeem the mortgage shall be commenced within ...

s. $33(2)$-Where there is a written acknowledgement of the mortgagor's title or of his right to redeem, then proceedings may be brought within ...

8. 34-An action given by a mortgagee or a person claiming through him for a foreclosure or sale under a mortgage of real or personal property must be brought within ...

8. 35(1)-Where a person bound to pay the interest or principal secured by the mortgage pays part of the money or interest to a person entitled to receive the same or his agent, the right to take proceedings for foreclosure or sale must be taken within...

s. 36(1)-An action by a purchaser in respect of the agreement for the sale of land must be commenced within ...

8. 36(2)-Where there has been part payment or a written acknowledgement, the right to take proceedings shall be deemed to start from after such part payment or acknowledgement and the action must be brought within ...

8. 39(1)-An action by a seller for the sale or recovery of goods subject to a conditional sales contract must be commenced within ...

8. $39(2)$-Where there is part payment or written acknowledgement, then an action may be brought by a vendor or a person claiming through him within ...

8. 46(3)-A person under a disability at the time the right to take proceedings first accrued to him must bring his action within ...
5 years next after the determination of the particular estate, which. ever of these 2 periods is the longer.

10 years after the time in which the mortgagee or a person claiming through the mortgagee obtained possession or first received any profits.

10 years after the time at which the acknowledgement, or the last of the acknowledgements, if more than one, was given.

10 years next after the right to take the proceedings first accrued to the mortgagee, or to a person claiming through the mortgagee.

10 years from the time at which payment or the last of the payments, if more than one, was made.

10 years after the right to take action on the agreement arose.

10 years thereof.

8. 37(1)-The same limitations apply to a vendor of land or a person claiming through him as apply to a purchaser as found in s. 36(1) and (2).

6 years after the right to take proceedings first accrued.

6 years thereof.

30 years after that time. 
Statute

Part 9-Tort and Related Actions

Line Fence Act, R.S.A. 1970 , c. 210

\section{Action or Remedy}

s. 47-Where a defendant is out of the Province at the time the cause of action arises against him within the Province, the action, other than one of those men. tioned in s. $5(1)(a)$ and (b) may be commenced within ...

s. 51-An action for defamation, trespass to the person, assault, battery, wounding or other injury to the person, false imprisonment, malicious prosecution, seduc. tion, trespass or injury to real property or chattels, or the taking away, conversion or detinue of chattels may be commenced within ...

s. 53-Except as provided in sections 57 to 61 , an action that may be maintained after the death of a person, as provided in section 51 or 53 of The Administration of Estates Act, may be commenced within ...

s. 54-Except as provided in sections 57 to 61 , an action under The Fatal Accidents Act may be commenced within ...

8. 55-Except as provided in sections 57 to 61 , an action against a qualified medical practitioner, a dentist, a chiropractor, a naturopath, a podiatrist, or an optometrist (optometrist included by 1973 , c. 13,8 . $7(2))$ for negligence or malpractice may be commenced within ...

s. 56-Except as provided in section 57 to 61 , an action against an approved hospital within the meaning of The Alberta Hospitals Act in respect of negligence in providing a service in that hospital may be commenced within ...

8. 58-Where a cause of action to which this Part applies arises within the Province against a person who is out of the Province at the time it arises, the person entitled to the action may commence the action within ...

s. 59(1)-A person under disability except infants in custody of their parents and mentally incapacitated persons under care of committees may commence an action at any time within ...

s. 61(2)-An amendment providing for a change of parties pursuant to the provisions of section 61(1) may only be made within...

s. 4(2)-An arbitrator may be appointed by an order of the Justice of the Peace where there is a dispute between adjoin. ing landowners or occupiers of land under the provisions of $8.4(1)$ where either of the parties refuses or omits to appoint an ar. bitrator within ...

\section{Limitation Period}

2 years after the return of the defendant to the Province or within the time otherwise limited by this Act for bringing the action.

2 years after the cause of action arose.

2 years from the date of the death of the person, and not afterwards.

2 years after the death of the person whose death gave rise to the cause of action under that Act, and not afterwards.

1 year from the date when the professional services terminated in respect of the matter that is the subject of the complaint, and not afterwards.

1 year after the cause of action arose, and not afterwards.

2 years after the return of the first mentioned person to the Province.

2 years from the date he ceased to be under disability.

3 months after the authorization is granted.

48 hours after demand is made in writing upon him to do so by the other party. 
Statute

Liquor Control Act, R.S.A. 1970, c. 211

The Liquor Licensing Act, R.S.A. 1970, c. 212

\section{Action or Remedy}

s. 59(1)-The Liquor Control Board may require the delivery of a return in such form and containing such details as may be prescribed by the Board by giving a notice in writing to the brewer to deliver his return within ...

8. 66-The Board may by notice in writing, require a distiller or wine maker to make returns and to permit the matters contained in this section to be done by sending a notice in writing which must be complied with within ...

s. $107(1)$-Where a person is under an interdiction order made pursuant to 8.100 of this Act, a judge, on application by the interdicted person may set aside the order which has been filed with the Board upon proof that the interdicted person has refrained from drunkness for at least ...

8. 107(3)-A person planning to set aside an interdiction order must give notice thereof to the Board in writing and serve such notice upon the Board at least ...

s. 113(3)-Seized liquor will be dealt with in the manner directed by the Board and shall become Board's property if no claim in writing is made within ...

8. 113(4)-A person claiming to be the owner of liquor may file with the Board a notice in writing giving at least three days notice of the time and places fixed by a justice for a hearing to prove his claim and his right under this Act to the possession of the liquor and packages within ...

s. 130(2)-The provisions of Part XXIV of the Criminal Code relating to appeals apply to any appeal from a conviction or order made in the prosecution of an offence under any provision of this Act. i.e., a notice of appeal shall be filed within ...

8. 12(4)-Where the Board suspends a licence without a hearing the licensee shall be given a hearing by the Board not later than...

8. 22(4)-A person claiming (under subsection (3)), the benefit of a licence issued to another party, may apply to the Board for a licence for the same premises in his own name in the manner of applying for a licence for the first time within...

8. 24(1)-No application for a licence by a person who has at any time or in any place been refused $a$ licence on the ground that he is not a fit person to hold the licence shall be entertained by the Board within...

8. 25(3)-A person may file an objection to the granting of a licence with the Board within...

\section{Limitation Period}

3 days after the day upon which the notice is received or within such further time as may be fixed by the Board.

3 days or such further time as may be fixed by the Board.

12 months immediately preceeding the application.

10 clear days before the application is made to a judge under subsection (1).

30 days from the date of its seizure.

30 days of the date of seizure of the liquor.

30 days after the conviction or order was made or the sentence was imposed whichever was the later.

30 days after the application for the hearing is received.

1 month of obtaining the permission to operate pursuant to subsection (2).

a period of one year from the last of the refusals.

14 days of the last issue of the newspaper con. taining notice of the application for a licence. 
Statute

The Liquor Plebiscites Act, R.S.A. 1970, c. 213

The Litter Act, 1972 , c. 61

\section{Action or Remedy}

8. 49(1)(b)(iv)-No club that has not previously been licenced under the Act shall be granted a licence to sell beer unless it has filed a notice of intention to make an application for licence at least...

s. 92(1)-The Lieutenant Governor in Council shall submit a question within ...

s. $93(2)$-Where less than $60 \%$ of the electors voting under a petition vote in the affirmative for a licence, the Board shall not consider the application or any further application for the class of licence voted upon before the expiration of ...

8. 97(4)-A petition under this section shall not be presented to the Board more than ...

8. 99(1)-Where in a plebiscite under $\mathbf{s}$. 92 , or under 8. $98,60 \%$ or more of the electors voting vote in the affirmative, no further question in respect of the class of licence voted upon may be submitted to a vote of the electors before the expiration of ...

8. 99(2)-Where under the authority of 8. 94, the Board may issue any class of licence in a local option area, no question in respect of that class of licence may be submitted to a vote of the electors before the expiration of ...

s. $100(\mathrm{c})$-Where, in a plebiscite under 8. $98,60 \%$ or more of the electors vote in the negative, no application for a licence of the class voted upon shall be considered by the Board before the expiration of ...

8. 13-Results of liquor plebiscites shall be transmitted to the clerk within ...

8. 14-The clerk shall publish a copy of the statement of the final count in the Alberta Gazette within ...

8. 9(3)-Where a clean up order is issued to a person pursuant to subsection (1) and subject to section 12 , the person shall perform the requirements of the order within ...

8. 10(1)-A person to whom a clean up order is issued may request the Minister to review the order or any part thereof within ...

s. 12(4)-Where there is a by-law in force in a municipality relating to unsightly property or premises, the Director may issue a clean up order to the local authority where such authority fails to com. mence proceedings to enforce its by-law within ...

\section{Limitation Period}

1 year prior to the date of application or has filed with the Board proof of organization of the club and a copy of its constitution and bylaws etc. at least 1 year before the date of application.

60 days after the receipt of a petition for a vote under 8. 91.

3 years after the date of the vote.

30 days before the date that, pursuant to section 99 , the plebiscite may be held.

3 years after the date of the plebiscite.

3 years from the date when the Board considered the first application.

3 years after the date of the plebiscite.

10 days after the holding of the final count.

30 days after the holding of the final count.

60 days from the date of the making of the order.

21 days of the date it is issued.

10 days of the date of the Director's request under subsection (3). 
Statute

The Livery Stable Keepers Act, R.S.A. 1970 , c. 214

The Livestock Brand Inspection Act, 1971, c. 63

The Livestock Products Act, R.S.A. 1970, c. 215

Amended by 1973, c. 36

The Livestock Diseases Act, 1971, c. 64

The Local Authorities Board Act, R.S.A. 1970 , c. 218

The Local Tax Arrears Consolidation Act, R.S.A. 1970 , c. 220

\section{Action or Remedy}

8. 12(5)-A clean up order issued pursuant to section 12 against a local authority shall be complied with not more than ...

8. 13(1)-A local authority to whom a clean up order is addressed may request a review of the order or any part thereof by the Minister within ...

s. 4(2)-A stable keeper may by public auction sell animals in his care or things in his care on giving two weeks notice of the sale where an owner does not reclaim the animal or things by discharging his indebtedness to the stable keeper within...

8. 6(1)-Surplus proceeds from a sale con. ducted pursuant to 8 . 4 will be paid over to the Provincial Treasurer and kept by him in a special account for one year where a person entitled to such proceeds does not apply for the surplus within ...

8. $49(1)-A$ person who knowingly has in his possession livestock found in estray must notify the brand owner or local inspector or must impound the animal in accordance with subsection (b), within ...

8. $50(2)-A$ prosecution under this section may be commenced within ...

s. 11(3)-A patron is not entitled to payment from the Fund in respect of a cheque from a livestock dealer which is dishonored unless the cheque is presented for payment within ...

s. $23(2)-A$ prosecution under this section may be commenced within ...

8. 9.1-No patron is eligible to make a claim or receive compensation pursuant to section 9 or section 11 unless he gives notice to the Minister by registered mail within ...

8. $15(2)-A$ prosecution under section $15(1)$ may be commenced within ...

8. $49(2)-A$ person entitled to notice who is not sufficiently notified may apply to the Board to alter or rescind the order or decision at any time within ...

8. 61(2)-An appeal lies from the Board to the Appellate Division of the Supreme Court of Alberta and leave to appeal to such court shall be obtained from a judge of the Court of Appeal upon application made within ... .

s. 7(2)-An applicant desiring to appeal from the council to the Minister shall deliver to the Treasurer a notice in writing stating his desire to appeal within...

\section{Limitation Period}

60 days from the date of the making of the order.

21 days of its date.

1 month from the time the indebtedness was incurred.

1 month from the date of the sale.

7 days.

2 years of the commis. sion of the offence and not thereafter.

60 days of the date of the cheque.

2 years of the commis. sion of the alleged offence but not afterwards.

60 days after the date that the livestock or livestock products were supplied to the person licenced.

2 years of an alleged offence but not thereafter.

10 days after becoming aware of any order or decision, or within such further time as the Board may allow.

1 month of the order, or such further time as the judge may allow.

7 days of the receipt of the notice from the Treasurer communicating a decision of the council. 
Statute

The Alberta Lord's Day Act, R.S.A. 1970 , c. 221

\section{Action or Remedy}

s. 8(2)-An applicant may appeal the decision of the Minister refusing an application to consolidate taxes to the Agricultural Relief Adjustment Board by sending by mail to the Minister a notice in writing of his intention to appeal within...

s. 8(4)-The Minister shall cause a copy of the notice to be sent to the Agricultural Relief Adjustment Board or to such person as is designated by him as the person to hear appeals unless he grants the application within ...

8. 15(3)-The applicant for an extension and waiver may appeal from a refusal to grant the application in the same manner and subject to the same conditions as are provided for by sections 5.7 and 5.8 .

i.e., under $5.7(2)$ within ...

and under 5.8(2) within ...

8. 26(3)-A school district forfeits all claims to taxes if it fails to furnish the treasurer with a statement of the outstanding taxes and the years for which they have been levied within ...

s. 7(2)-The council may give third reading to a proposed by-law and pass it unless a petition for a vote on the proposed bylaw is presented to the council within ...

8. 7(3)-The council shall submit the proposed by-law to a vote of the electors of the municipality if a petition for a vote on the proposed by-law is presented to the council within ...

8. 8(3)-The council shall at its next meeting give third reading to a proposed by-law and pass it unless a petition for a vote on the proposed by-law is presented within ...

8. $9(b)-W h e r e$ a majority of electors do not favour a by-law, no similar Sunday by-law or by-law to amend a Sunday by-law may be passed by the council until at least...

s. 10(1)-A Sunday by-law may be repealed only after the expiration of at least...

and in such case no similar Sunday by-law may be passed until the expiration of at least ...

8. 10(2)-A provision in a Sunday by-law specifying an activity mentioned in 8.4 may be repealed only after the expiration of ...

\section{Limitation Period}

14 days after he has been notified of the decision of the Minister.

30 days after the receipt of the notice given pursuant to subsection (2).

7 days of the receipt of the notice from the treasurer;

14 days of being notified of the decision of the Minister refusing the application.

30 days after receiving notice from a municipality that an application for consolidation has been made.

15 days after the last publication of the notice.

15 days of the last publication of the notice.

15 days after the last publication of the notice.

3 years after the holding of the vote.

3 years after the by-law came into force;

3 years from the date on which the previous by. law was repealed.

3 years from the date the provision came into force; 
Statute

The Maintenance Order Act, R.S.A. 1970 , c. 222

The Maintenance and Recovery Act, R.S.A. 1970 , c. 223

The Marketing of Agricultural Products Act, R.S.A. 1970, c. 225

Amended by 1972 , c. 65

The Masters and Servants Act, R.S.A. 1970 , c. 228

\section{Action or Remedy}

and in such case no by-law containing a similar provision may be passed until ...

s. 7(1)-A person against whom an order has been made under this Act for the maintenance of a person who is a patient in a hospital shall remove the patient from the hospital within ...

s. 14(1)(a)-An order may not be made against a putative father unless the complaint is made within his lifetime and not later than ...

s. 14(1)(b)-An order may not be made pursuant to this section unless the complaint is made within...

s. 16(3)-A judge may, in his discretion, direct a rehearing and may confirm or reverse any order made pursuant to subsection (1) where an application is made for a variation of an order within ...

s. 40(2)-A judge may, in his discretion, direct a rehearing and may confirm or reverse or vary any order made pursuant to subsection (1), where the person against whom the order is made applies within ...

s. 26(1)-A person considering himself aggrieved by an order, direction, regulation or decision of a producer board or marketing commission may appeal to such board by serving a written notice of appeal within ...

s. 26(2)-A person may appeal to the Council from a decision made pursuant to subsection (1) or from an order, direction or regulation made by the Council by serving upon the Council written notice of the appeal within ...

s. 26(5)-In any appeal under subsection (1) or (2), the council shall serve notice upon the person making the appeal, of the date, time and place at which the appeal will be heard within ...

8. 10.1(8)-A producer who is not satisfied with a decision of the board, may appeal in writing to the Council for a reduction in the determination and the service charge in accordance with the provisions of section 26 . (see above).

s. 10-Proceedings under this Act must be commenced within the later of ...

\section{Limitation Period}

3 years from the date on which the previous provision was repealed.

10 days from the receipt from the hospital Board of a written notice requiring him to do so.

24 months after the birth of the child or termination of the pregnancy.

the 12 months next after the doing of some act on the part of the putative father that could reasonably be regarded as an acknowl. edgement that he caused or possibly caused the pregnancy.

30 days of the making of the order.

30 days of the making of the order.

30 days of the date he receives notice of the decision, order, direction or regulation in question.

30 days of the date he receives notice of the decision, order, direction or regulation in question.

7 days after the notice referred to in subsection (1) or (2).

(a) 6 months after the end of the employ. ment, or

(b) 6 months after the last wages due. 
Statute

The Medical

Profession Act,

R.S.A. 1970 , c. 230

The Mental Health

Act, 1972 , c. 118

Amended by 1973 , c. 76

\section{Action or Remedy}

8. 10(2)-A complainant who is dissatisfied with the decision of the registrar may appeal to the Supreme Court of Alberta not less than ...

s. 39(1)-A person who is dissatisfied with an order of the council pursuant to 8.32 or section 37 may apply for a review of the council's decision to the Minister within...

8. 48(3)-A registered practitioner shall be suspended from the privileges of a registered practitioner until a judgment made by the council is complied with unless he complies with the judgment of the council within ...

8. 51(1)-A registered practitioner who has been suspended or otherwise dealt with by order of the council may appeal to the Supreme Court of Alberta within ...

8. 64(1)-A person whose name has been ordered to be removed from the register may appeal to the Supreme Court of Alberta within ...

8. 80-A prosecution under this Act may be commenced at any time within...

8. 38(5)-An application for cancellation of a certificate of incapacity may be made to a review panel by a formal patient or a person on his behalf...

s. 41(3)-The chairman of the review panel shall send a written report of its decision to the applicant, the Public Trustee and the nearest relative within ...

8. 46(1)-An applicant may appeal the decision of a review panel by originating notice of motion to the Supreme Court within ...

8. 46(3)-The notice of motion shall be served upon the Minister, the chairman of the board of the facility in which the applicant is a patient and such other persons as the court may direct, not less than ...

8. 26(1)(a)-A conveyance and examination certificate is sufficient authority for any person to convey the person named therein to a facility and to detain that person while he is being so conveyed until the time he arrives at that facility within ...

8. 30(1)-Two admission certificates are sufficient authority to observe, examine, care for, treat, control and detain the person named therein, in a facility for a period of ...

\section{Limitation Period}

10 days before the date fixed for the election.

30 days after the date of the order of the Council.

30 days after receiving a written notice from the registrar of the finding of the Council.

30 days of the date of the order of the council.

90 days after the date of the order for the removal.

12 months after commis. sion of the offence, but not thereafter.

twice each year, but the Minister, the Public Trustee, the Director or a board may apply at any time.

7 days of the date of its decision.

14 days of the decision of the review panel.

15 days before the motion is returnable.

72 hours of the time the conveyance and examin. tion certificate is issued.

1 month from the date the second admission certificate is issued. 
Statute

The Mentally

Incapacitated Persons

Act, R.S.A. 1970, c. 232

The Mineral Taxation Act, R.S.A. 1970, c. 236

\section{Action or Remedy}

s. $30(2)(a)$-Where a person named in two admission certificates is not in a facility, the certificates are sufficient authority for any person to convey the person named therein to a facility within ...

(b) The certificates are sufficient authority for any physician to prescribe treatment for or to treat the person named therein while he is being 80 conveyed and for a period of ...

8. 31(2)-Two renewal certificates are sufficient authority to observe, examine, care for, treat, control and detain the person named therein

(a) in the first case where two renewal certificates are issued for a period of not more than ...

(b) in the second case and each subsequent case where two renewal certificates are issued, for a period of not more than ...

s. 9(1)-A person alleged to be of unsound mind may demand a trial of the issue of his unsoundness of mind by a jury if he gives notice in writing to the person applying for the declaration at least ...

8. 11(1)-The court may order that a person has become of sound mind or direct an issue to try the question of the person's restoration to sanity upon application at any time after the expiration of ...

8. 13(1)-An owner whose name appears on an assessment roll may appeal the assessment after the date on which the assessment notice is mailed and on or before ...

s. 13(2)-The Deputy Minister may appeal to the Board upon giving the Board notice in writing within ...

8. 13(5)-A person entitled to appeal under subsection (4) may give his notice in writing to the Board and the Deputy Minister on or before...

or within ...

\section{Limitation Period}

72 hours of the time the second admission certificate was issued, and

24 hours from the time he arrived at the facility.

2 additional months;

6 additional months.

10 days before the trial.

1 year from the date of the order by which a person has been declared of unsound mind, or sooner by leave.

the 31st day of July next following.

30 days after the date of posting the copy of the assessment roll and the certificate with the Department at Edmonton.

the 31st day of July, next following, if the notice prescribed by subsection (3) is sent from the office of the Deputy Minister on or before the 15th of July;

15 days from the date on which the notice prescribed by subsection (3) is sent from the office of the Deputy Minister if such notice is sent after the 15th day of July. 
Statute

Amended by 1972 , c. 67

The Mines and Minerals Act, R.S.A. 1970 , c. 238

\section{Action or Remedy}

8. 14(1)-An owner whose name appears upon the assessment roll may appeal to the Board by giving notice in writing to the Board and the Deputy Minister on or before...

s. 14(2)-The Deputy Minister may appeal to the Board by giving the Board notice in writing within ...

8. 14(5)-A person entitled to appeal under subsection (4) may give his notice in writing to the Board and the Deputy Minister, on or before...

or within ...

s. 40-Interest shall be charged at the rate of $6 \%$ per annum from the due date of any money payable under any disposition which is not paid within ...

s. 51(1)-Well casings and fixtures vest in the Crown in right of Alberta upon the expiration of ...

8. 52(1)-Subject to subsection (2) a mine or quarry vests in the Crown in right of Alberta being clear of all claims, charges or liens whatsoever upon the expiration of ...

8. $73(1)-A$ report accounting for the full quantity of coal mined during the preceding month shall be filed with the Department not later than ...

8. 73(2)-A report by a lessee of coal mines stating which coal rights are not being mined shall be furnished to the Department at least ...

8. 74(1)-A lessee shall commence mining operations on the location within ...

8. 74(2)-A notice under subsection (1) shall not be given until the expiration of at least...

8. 95(1)-A lessee of quarry minerals shall file with the department a report accounting for the full quantity of the mineral obtained during the preceding month not later than ...

\section{Limitation Period}

the next following April 30 th after the date upon which the assessment notice is mailed.

30 days after the date of posting the copy of the assessment roll and the certificate in the Department at Edmonton, and the Land Titles Office in Calgary.

the next following April 30 th if the notice prescribed by subsection (3) is sent from the office of the Deputy Minister on or before April 15th;

15 days from the date in which the notice prescribed by subsection (3) is sent from the office of the Deputy Minister, if such notice is sent after April 15th.

1 month or 30 days, whichever is the greater from the date on which it became due.

6 months following the date that an agreement is cancelled, forfeited or surrendered.

6 months following the date that an agreement is cancelled, forfeited or surrendered.

the 25th day of the month.

once every 3 months.

1 year from the date upon which he is notified by the Minister to do 80 .

1 year from the date of the lease.

the 25th day of the month. 


\section{Action or Remedy}

s. 96(1)-A lessee shall commence quarrying operations on the location within ...

s. 96(2)-A notice under subsection (1) shall not be given until the expiration of at least...

s. 103(2)-If a lessee fails to submit evidence satisfactory to the Minister of his ownership and right to mine coal from land adjoining his road allowance leases, the Minister in his discretion may cancel the lease within ...

8. 105(2)-Where coal rights and a road allowance are held under lease but do not adjoin a location subject to royalties as prescribed by $8.78(1)$, the lessee shall have the workings of the mine surveyed insofar as they relate to the area included in the road allowance at least every 12 months and shall furnish a report of the quantity of coal mined during such period from such road allowance within ...

8. 125-The term of a petroleum and natural gas lease shall be...

8. 126(1)-The lease continues as to the part of the location within the spacing unit for each producing well and in respect of each producing well in the location as to any remaining part of the location which added to the area continued in respect of that well under clause (a) does not exceed one section upon the expiration of the ...

8. $127(1)-U$ pon the expiration of the 10 year term of any lease where the rental is reduced under section 124, the lease continues as to the whole of the location until ...

8. 127(2)-Where subsection (1) applies, the lease further continues as to that part of the location that would continue under section 126 as though the expiration of the period of 6 months referred to in subsection (1) were the expiration of ...

8. 128(1)-Upon the expiration of the 10 year term, the lease continues as to any part of the location that is subject to a unit operation until...

s. $128(2)-$ Where subsection (1) applies, the lease further continues as to that part of the location that would continue under section 126 as though the expiration of the period of 6 months referred to in subsection (1) were the expiration of ...

8. 129-Upon the expiration of the 10-year term, the lease continues as to any part of the location that is within a spacing unit in respect of which the period for the drilling of an offset well is extended under section 135 , until...

\section{Limitation Period}

1 year from the date upon which he is notified by the Minister to do 80 .

1 year from the date of the lease.

30 days from the giving of the notice referred to in subsection (1).

30 days after the survey has been completed.

10 years.

10 year term.

6 months after the reduction in rental ceases.

the 10 year term.

6 months after it is no longer subject to a unit operation.

the 10 year term.

6 months after the freehold well ceases production. 
Statute

Amended by 1972 , c. 68

The Mobile Equipment Licensing Act, R.S.A. 1970 , c. 241

The Mortgage Brokers Regulation Act, R.S.A. 1970, c. 242

The Motor Vehicle Accident Claims Act, R.S.A. 1970, c. 243

\section{Action or Remedy}

s. 146-A lessee or his agent shall file with the Department a full report of the production, disposition and sales of petro. leum or natural gas during the preceding month not later than the . .

s. 154(1)-Subject to subsection (4) a lessee under a natural gas lease shall commence drilling of a well within ...

8. 154(2)-A lessee under a natural gas lease shall commence the drilling of a subsequent well within ...

8. 164(1)-A lessee of petroleum and natural gas rights under the Provincial Lands Act or the former Act shall commence drilling operations on the location within ...

s. 166(1)-A well shall be considered a continuation of an abandoned well if it is commenced within ...

8. 193(1)-A licensee shall supply a report containing a complete copy of every log or survey taken of each hole logged or surveyed to the Oil and Gas Conservation Board not later than ...

8. 193(3)-A licensee shall supply to the Director a report of water occurrences and a report of gas occurrences not later than ...

8. 193(4)-A licensee shall supply to the Director a map or maps showing the area covered by exploration not later than ...

8. 125.1(1)-Subject to subsections (2) and (3), a lessee shall commence drilling operations on the location within ...

8. 19-A prosecution for an offence under this Act may be commenced at any time within ...

8. 24-A person upon whom a notice is served under section 23 or who is affected by any direction, decision, order or ruling of the commission may request a hearing and review by giving notice in writing to the registrar within ...

8. 30(2)-An appeal from an order made upon every review shall be by notice of motion which shall be served upon the registrar within ...

s. 9(1)-Where a plaintiff notes a defendant in default pursuant to an action for damages under section 9 , he shall serve upon the Administrator a notice in writing advising him of the facts and shall not take the next step in the action until...

\section{Limitation Period}

25 th day of the month.

6 months of being notified by the Minister to do so.

(a) 6 months of the completion or abandonment of a well in the location, or

(b) within such longer period as the Minister may prescribe.

1 year from the date that the Minister gives notice requiring him to do so.

30 days of the abandon. ment of the drilling of the other well.

3 months after the termination of the licence.

3 months following the termination of the licence.

3 months following the termination of the licence.

one year from the date the Minister gives notice requiring him to do so.

2 years of the commission of the alleged offence.

30 days after the mailing of the notice.

30 days after the mailing of notice under section 29.

30 days after the service of the notice. 
Statute

The Municipal Election Act, R.S.A. 1970, c. 245

\section{Action or Remedy}

s. 9(2)-Where the conditions of this subsection exist the plaintiff may serve upon the Administrator a notice in writing advising him of the facts and shall not take the next step in the action until...

s. 9(4)-At any time within the 30 days mentioned in subsection (1) or (2) the Administrator may notify the plaintiff that he intends to make an investigation and the plaintiff shall not take the next step in the action until ...

8. 13(2)-No action may be brought against the Administrator pursuant to subsection (1) unless a notice in writing is served upon the Administrator within...

s. 13(3)-An action under subsection (1) against the Administrator may be commenced only within ...

8. 45(1)-Any person may apply to have his name added to the electoral list at any time during office hours of any business day up to and including ... .

8. 126(3)-An application for a recount pursuant to 8 . 126 may be made by a candidate during ...

8. 132(1)-An elector may apply to the District Court by notice of motion for a recount after fulfilling the conditions in this subsection and subsection (2) at any time within ...

s. 133-A copy of the notice of motion and affidavit filed shall be served by the elector upon the municipal secretary, the returning officer and all such candidates as the judge may direct at least ...

8. 144-Sections 132 to 143 apply mutatis mutandis to a recount of the vote for and against a by-law or question. (section 132 (1), 133).

8. 166-No proceedings against a person for bribery or undue influence may be commenced after...

s. 169(1)-A judge may grant a fiat authorizing the service of a notice of motion in the nature of a quo warranto to determine the issue of the legality or validity of an election or money by-law where a person raises the issue within ...

s. 172(2)-Service of the notice of motion shall be made within ...

\section{Limitation Period}

30 days after the service of the notice.

30 days after being so notified by the Administrator.

90 days after the cause of action arose or within such longer period as the court may allow.

the time limited by the Limitation of Actions Act for bringing an action against the owner or operator of the vehicle.

the 8th day before the date established for polling day.

the 72 hour period immediately following the closing of the polls but may not be made thereafter.

15 days from the time of the declaration of the result of an election by the returning officer.

3 days prior to the application.

6 weeks from the day of the election or the voting upon the by-law in respect of which the offence is alleged to have been committed.

6 weeks after an election or a voting upon a money by-law.

2 weeks from the date of the fiat granted by the judge unless otherwise ordered by the judge. 
Statute

The Municipal

Government Act, R.S.A. 1970 , c. 246

\section{Action or Remedy}

s. $185(1)-A$ person may serve a notice of disclaimer within...

8. 14(3)-Any person may file an objection to the formation of the proposed municipal district, village or summer village within ...

s. 17(8)-A liquidator shall publish a notice requiring every person who has a claim against a municipality to furnish the liquidator with particulars in writing thereof within...

8. 111(1)-Subject to subsection (2) and the conditions set out in subsection (1) a by-law is valid and binding notwithstanding any lack of compliance with a provision of this Act unless an application to quash is made within ...

8. 126(2)-If an annual meeting is held, it shall be held not later than March 318t and notice of the meeting shall be given by causing it to be mailed at least ...

or published in an issue of a newspaper circulating within the municipality once a week for two successive weeks, the last of which shall be published not less than ...

8. 135(1)-Any person who has land adjoining land being developed by a municipality whose land is damaged by the development may file a claim for damages in respect thereof with the municipal secretary at any time after the damage has been sustained and within ...

8. 135(6)-Any claim under this section for damages resulting from a municipal work is forever barred and extinguished unless the claim is filed pursuant to 8 . 135(1) within ...

8. 157(4)-Any owner, agent, lessee or occupier receiving a notice to abate a nuisance or to remedy any condition that constitutes a nuisance and who thinks himself aggrieved, may appeal to the Supreme Court within ...

8. 158(7)-A person thinking himself aggrieved by an order made pursuant to this section may have the order set aside, varied or modified within ...

8. 159(3)-If an owner appears by himself or through his agent before the council and is dissatisifed with the disposition he may appeal to the SupremeCourt within...

\section{Limitation Period}

1 week after service upon him of notice of motion complaining of the election or alleging disqualification.

30 days from the date of notice referred to in subsection (2).

30 days after his appointment, and the period for filing of the claim shall be not less than 40 days nor more than 60 days after the publication of the notice.

2 months next after the final passing of the bylaw.

16 clear days before the date of the meeting to each resident of the municipality;

7 clear days prior to the date of the meeting.

60 days after notice has been given in a newspaper of the completion of the work or structure in respect of which the damage is sustained.

60 days after notice has been given in a newspaper of the completion of the work or structure in respect of which the damage is sustained.

10 days from the receipt of the notice.

30 days from the date of the making of the order.

30 days from the date of the disposition. 
Statute

Action or Remedy

s. 183(9)-No complaint that a default has been made by a council in performing a duty imposed upon the council by subsection (1) shall be lodged after the expiration of ...

and unless notice in writing of the default has been mailed to or served upon the municipal secretary within ...

s. 221(2)-A person carrying on or engaged in any business requiring a licence provided for in this Act is guilty of an offence where he fails to furnish licence informa. tion within ...

8. 239(5)-A person entitled to notice under subsection (4) may appeal to the development appeal board of the municipality or where no development appeal board is established, to the council within...

s. 250(4)-A notice from the council to an owner of land to remove obstructions at road intersections shall be served upon the owner not less than ...

8. 250(5)-When the owner is not resident in Alberta or his present address is unknown, the notice shall be served upon him at his latest known address not less than ...

s. 259(1)-The municipal district shall cause a notice to be published in the Gazette regarding an advance made to a person and shall register the agreement for a lien in the Land Registry Office within ...

s. 259(3)-A lien is created upon all crops grown from any seed supplied pursuant to this Act at any time within ...

except liens that pursuant to the Crop Liens Priority Act or prior to the lien created by this section where the notice of the advance is made in the Gazette within ...

8. 263(2)-Where a mortgage is required pursuant to subsection (1) the mortgage shall be registered within ...

s. 267(9)-A council may pass a by-law to extend an agreement under this section unless a petition signed by at least $10 \%$ of the proprietary electors of the area to which an agreement under this section applies is received by the municipal secretary with in ...

\section{Limitation Period}

2 years from the date the alleged default occurred,

60 days after the day on which the cause of complaint arose.

10 days from the date on which the request is made.

14 days of the receipt of the notice requiring minimum standards for buildings.

2 weeks preceding the date that the resolution authorizing the municipal district to make the removal is first presented to the council.

3 weeks preceding the date the resolution is first presented to the council.

90 days of the making of an advance for the purpose of supplying a commodity to such person.

12 months after the advance referred to in the notice and has priority over all claims and demands of any nature;

90 days after the making of the advance pursuant to this Act.

60 days instead of 30 days as prescribed by the Bills of Sale Act.

15 days of the last of two publications in a newspaper circulating in the municipal district of a notice to the effect that council intends to extend the agreement. 
Statute

\section{Action or Remedy}

8. 270(3)-The provisions of section 311 relating to the requirement of advertising and if necessary submitting the matter to a vote of the proprietary electors apply mutatis mutandis to a public utility by-law. The same provisions apply to the purchase of a public utility.

8. 311(2)-Notice of the proposed by-law shall be given once a week for two consecutive weeks in a newspaper circulating in the municipality within ...

8. 311(3)-The council shall submit the bylaw to a vote of the proprietary electors if a number of proprietary electors referred to in this subsection petition for a vote on a by-law and the petition is received by the municipal secretary within ...

8. 325(5)-Notice of intention to redeem a debenture prior to its maturity shall be sent by post to the person in whose name the debenture is registered at least...

8. $343(2)-$ No debenture shall be issued after the expiration of ...

s. 344(b)-An application to quash a debenture must be successfully brought within ...

8. $384(1)$-Where any by-law or resolution is illegal in whole or in part, or where anything has been done under it that by reason of such illegality gives any person a right of action, no such action shall be brought until...

8. $385(1)$-Subject to sections 387 and 388 , written notice of an intention to bring an action against a municipality must be served upon the municipal secretary or municipal solicitor within ...

s. $387(2)-N o t i n g$ the qualification set out in (1) no action shall be brought to recover for any damage to property or person sustained by reason of the existence of snow, ice or slush upon any street, sidewalk or highway in the municipality unless notice in writing of the claim and of the injury complained of has been served upon or sent by registered mail to the municipal secretary within ...

8. 388-No action shall be commenced against a municipality for damages occasioned by default in the municipality's duty of repair referred to in section 178 unless notice in writing of the claim and of the injury complained of has been served upon or sent by registered post to the municipal secretary within ...

\section{Limitation Period}

See limitation period under section 311. (see below)

21 days from the date of the issuance of an order or other authorization by the Local Authorities Board approving a bylaw.

15 days of the last publication of the notice referred to in subsection (2).

30 days prior to the date set for such redemption.

6 years from the final passing of the by-law authorizing the issue.

2 months after the final passing of the debenture.

1 month after the by-law or resolution has been quashed or repealed, nor until 1 month's notice in writing of the intention to bring the action has been given to the municipality.

6 months of the happening of the accident.

Note: qualifications in subsection (2).

21 days after the cause of action arises.

60 days after the happening of the injury. Note: $8.389(1)$ and (2)qualifications on the limitations referred to in sections 385,387 and 388. 
Statute

The Municipal and Provincial Properties Valuation Act, R.S.A. 1970 , c. 248

\section{Action or Remedy}

s. 397(3)-A notice of motion to quash any by-law, order or resolution of the council in whole or in part for illegality shall be served at least ... .

s. 397(9)-Except where a by-law requires the assent of the electors and it has not been submitted to or has not received such assent, no application to quash a by-law, order or resolution in whole or in part shall be entertained unless the application is made within ... .

s. $407(3)$-The sheriff shall strike a rate sufficient to realize the amount claimed in the writ of execution against a municipality together with interest and his own fees if the amount stated in the writ is not paid to the sheriff within ...

8. 407(6)-After satisfying the execution and all fees thereon, the sheriff shall return any surplus to the treasurer within ...

8. $409(1)-M o n e y$ deposited with a municipality by any person as a guarantee deposit for the payment of accounts of the municipality with respect to water, light, telephone or other utilities shall be transferred to the General Revenue Account if it remains unclaimed for a period of . . .

8. 409(2)-The deposit becomes the absolute property of the municipality free from any claim in respect thereof after...

s. $410(2)$-Lost and unclaimed property held by the municipality will be sold by public auction unless claimed within ...

8. 410(4)-The proceeds from a sale pursuant to this section form part of the General Revenue of the municipality if no claim is made to such proceeds within ...

Note: refer to The Municipal Taxation Act

The Municipal Tax Exemption Act, R.S.A. 1970 , c. 250
8. 4(2)-Where an application for an exemption is refused under this Act, no further application in respect of the same property or a portion thereof may be made by the same organization within ...

s. 6(2)-A municipality shall be deemed to have no objection to an exemption being granted if it does not comply with subsection (1) within ...

\section{Limitation Period}

7 clear days before the day on which the motion is to be made.

2 months, or in the case of a by-law passed under section 139, 1 month from the passing of the by-law, order or resolution.

30 days after service of the writ and the statement.

10 days after receiving it.

5 years after the account of the depositor has been discontinued.

10 years following the discontinuance of the accounts.

3 months after its coming into the hands of the municipality.

one year from the date of sale.

The time limitations contained in The Municipal Taxation Act relating to the mailing of assessment notices, complaints as to assessments and the right of appeal from assessments apply mutatis mutandis to any property that becomes liable to assessment and taxation under this Act.

1 year from the date of the refused application.

40 days after the receipt by it of a copy of the application for exemption. 
Statute

Amended by 1971, c. 77

The Municipal

Taxation Act,

R.S.A. 1970 , c. 251

\section{Action or Remedy}

8. 7(1)-Upon receipt of an application, the Board shall fix a date for a hearing to investigate the application and shall give not less than ...

8. 9(2)-An organization shall be deemed to have no objection to an exemption being rescinded or varied if it does not comply with subsection (1) within ...

8. 10(1)-Upon receipt of an application for a review, the Board shall fix a date for a hearing of the application and shall give not less than ...

8. $13(2)-N o t e:$ reference to limitation provisions in The Municipal Taxation Act ...

8. 17 (4) (amended by 1972, c. 70 8. 8 )-Notwithstanding section 32 a special franchise shall be reassessed not later than ...

8. 37(4)-A prosecution under subsection

(3) may be commenced within ...

8. $39(4)-A$ person wishing to object to a business assessment may launch a complaint in writing with the municipal secretary or the assessor within ...

8. $41(1)-T h e$ municipal secretary or the assessor shall cause to be published in one issue of the newspaper having general circulation in the municipality, a notice in the prescribed form that the assessment roll has been prepared pursuant to 8 . 36 not later than ...

8. 45(3)-A person wishing to complain regarding an assessment may complain to the court of revision by notifying the municipal secretary in writing of the particulars and grounds for his complaint in a notice to be handed to the municipal secre tary in person or sent him by mail (a) within ...

(b) (amended by 1972 , c. 70 s. 17)-Where no assessment slip was mailed ...

8. 46(2)-A notice of the sittings of the court of revision shall be sent by mail to any person affected at least ...
Limitation Period

40 days' notice of the date and place of the hearing to the municipality and to the applicant.

40 days after the receipt by it of the copy of the application for rescission or variation.

40 days' notice of the date and place of the hearing to the municipality and the organization affected thereby.

The provisions of The Municipal Taxation Act relating to assessment notices, assessable pro perty, complaints, and the right to appeal from assessments apply $m u$. tatis mutandis to an assessment made up by a by-law of the municipality. (Note: This section is not yet in force.)

December 31st in each year.

2 years of the commis. sion of the offence but not thereafter.

30 days from the date of the mailing of the assessment notice.

the 1st day of January next following.

30 days after the mailing of the assessment slip to the complainant as required by 8 . 39 ; or,

during the month of January next following the completion of the assessment roll.

10 days before the sitting of the court of revision. 
Statute

Amended by 1972 , c. 70

R.S.A. 1970, c. 251

\section{Action or Remedy}

8. 57(1)-An appeal against a decision of the court of revision pursuant to 8.56 may be made within ...

8. 57(2)-An appellant shall by personal service or by registered mail, serve a written notice of appeal upon the municipal secretary within ...

8. 58(1)-The municipal secretary shall forward a list of all notices of appeal and particulars of assessments under appeal to the Appeal Board not later than ...

8. 62(2)-Where an error, omission or misdescription on an assessment slip has influenced a person from complaining against the assessment within the time allowed under 8. 45, that person is entitled to receive a corrected assessment slip and he may complain to the court of revision against the assessment as shown on the corrected slip within ...

s. 62.1(3)-The provisions of this Act relating to the mailing of assessment slips, complaints as to assessments and the right of appeal from assessments apply with the necessary modifications to amended assess. ments.

8. 75(3)-A person is guilty of an offence and liable on summary conviction to a fine of not more than $\$ 10$ per day for each day default is made in furnishing information required by an assessor where such person is able to provide such information and fails to do so within ...

s. 86(3)-A refund of any overpayment of business tax shall be made only when an application therefore is received by the municipal secretary on or before ...

8. 88-The provisions of this Act relating to the mailing of assessment notices, complaints as to assessments, and the right of appeal from assessment apply, mutatis mutandis, to business assessments.

8. 114(6)-No penalty under this section for unpaid taxes shall be imposed before...

8. 119(5)-The municipal secretary shall, by registered mail, notify the insurer of the full amount of taxes due within ...

8. 124-The municipal secretary may levy the taxes with costs by distress upon those things enumerated in subsections (a) through (d) where taxes remain unpaid in the case of a resident of the municipality for...

\section{Limitation Period}

21 days after the mailing or personal service of the notice required by section 54 upon the person appealing.

the time limited by subsection (1).

7 days after the expiry of the time limited for service of the notice of appeal.

30 days of the mailing of the corrected assessment slip.

30 days after the date of the demand by the assessor.

December 31st of the year following the year of the business tax levy.

the first day of July in any year.

15 days after the mailing of a notice pursuant to subsection (4) of any loss, or damage to property which may result in a charge arising under 8. 119 .

14 days, or in the case of a non-resident for one month after the mailing of the tax notice. 
Statute

The Municipalities Assessment and Equalization Act, R.S.A. 1970, c. 252

The Naturopathy Act, R.S.A. 1970, c. 257

The New Towns Act, R.S.A. 1970 , c. 258

The Nursing Homes Act, R.S.A. 1970, c. 264

\section{Action or Remedy}

s. 127(4)-A copy of an appointment for examination of a farmer regarding disposition of his crops where taxes are owing must be served at least...

8. 135(6)-The municipal secretary shall notify the owner of land by registered mail of the intentions of the municipality to proceed with collection of rent under this section not less than ...

8. $138(1)-$ The municipal secretary shall give at least ...

8. 153(3)(b)-A local improvement proposed by the Council on its own initiative may be undertaken and the cost thereof assessed against the owners unless in accordance with 8. 153, such owners petition the council against the proposed im. provement within ...

8. $177(3)$-The time fixed in the notice of a special assessment sitting shall not be earlier than ...

8. 13(2)-A person may appeal an assessment by giving notice to the Alberta Assessment Appeal Board within ...

s. 22(2)-An appeal by a municipality or the Minister from an equalization of assessment order may be commenced by giving notice to the Board within ...

8. 22(4)-The date of the hearing shall not be sooner than ...

s. 8(8)-A member suspended or expelled from the Association may appeal from the decision of the council to a judge of the Supreme Court of Alberta at any time within ...

8. 23-A prosecution under this Act may not be commenced after . . .

8. 25(5)-A naturopath whose right to practise in the Province is suspended or cancelled may appeal to a judge of the Supreme Court of Alberta within ...

8. 25(6)-The appointment shall be served upon the chairman of the discipline com. mittee ...

s. 8(6)-An election ordered by the Minister under this section shall be conducted under The Municipal Election Act, which applies mutatis mutandis thereto.

8. 11(3)-The operator of a nursing home may appeal a suspension or cancellation of his contract to the Lieutenant Governor in Council within ...

\section{Limitation Period}

4 clear days before the date fixed for the examination.

14 days prior to the date on which action under this section is to be taken.

10 days public notice of the time and place of sale of distrained goods.

2 weeks of the last publication of the notice pursuant to section 153(1).

21 days from the date of the delivery or mailing of the notice or the date of the first publication in a newspaper.

30 days after the date of the sending out of the notices of assessment or order, as the case may be.

60 days after the date of the sending out of the notification referred to in $8.21(3)$.

the 10th day after the mailing of the notice.

14 days after the date of the order or resolution of suspension, or within such further time as a judge of the Supreme Court may order.

1 year from the date of the alleged offence.

14 days after the suspension or cancellation, or within such further time as the judge may allow.

7 days before the date fixed by the judge for the hearing of the appeal.

See limitation periods listed under The Municipal Election Act.

30 days of receiving a notice of suspension or cancellation. 
Statute

The Off-Highway

Vehicle Act, 1972, c. 73

The Oil and Gas Conservation Act, R.S.A. 1970 , c. 267

Amended by 1971, c. 30

\section{Action or Remedy}

s. 7(2)-A person may operate a second off-highway vehicle using the licence plates from the first vehicle if application is made therefor within ...

s. 25(3)-The Board, at its discretion may cancel a licence or suspend a licence if the licencee fails to prove that he is entitled to the right to produce oil, gas or crude bitumen from a well after...

s. 31(b)-The Board may cancel a licence if drilling has not been commenced with. in ...

8. 64(1)-A person named on an assessment roll or the Board's solicitor or other employee of the Board may apply to the board for a variation of the assessment by giving the Board notice in writing within ...

8. 71-The Board may make a seizure of oil and gas when the tax payable to the Board in respect of any oil and gas property or any interest therein is not paid within ...

s. 76(1)-A person affected by a decision of the Board which raises a question of law may require the question to be referred to a judge by giving notice in writing to the Board within...

s. 84(4)-The Board may terminate a pooling order without notice or hearing notwithstanding the other provisions of this section where an order pursuant to section 82 requires a well to be drilled and a well is not drilled within ...

s. 41(1)-A person affected by an order made by the Board without a hearing may apply to the Board for a hearing within ...

s. 41(2)-A person affected by an order or direction by the Board after a hearing and to whom notice of the hearing was not given may apply to the Board to vary, amend, or rescind the order or direction within ..

8. 41(5)-The Board shall hold a public hearing upon an application made under this section after giving not less than ...

8. 42(2)-Upon obtaining leave to appeal upon a question of jurisdiction or upon a question of law, a person affected by an order of the Board may appeal to the Appellate Division within ...

s. 42(4)-The Board shall forward to the Registrar the transcript and record of the hearing and its findings and reasons for the order within ...

8. 140-Every information or complaint for the prosecution of an offence under this Act shall be laid or made within ...

\section{Limitation Period}

14 days after acquiring ownership of the second vehicle.

30 days from the mailing of a notice of the board.

6 months of the issue of the licence.

30 days after the date upon which the certi. ficate of the assessor was first posted pursuant to s. 63 .

30 days after the mailing of the notice referred to in s. 69 .

30 days after the date upon which the decision was made.

the time specified in the order.

30 days after the date upon which the order or direction was made.

30 days after the date upon which the order or direction was made.

10 days notice to all persons affected by the order or direction.

1 month after the making of the order, decision or direction.

30 days after leave to appeal has been obtained pursuant to subsection (2).

18 months from the time when the subject matter of the proceedings arose, and not afterward. 
Statute

The Ophthalmic

Dispensers Act,

R.S.A. 1970 , c. 269

The Optometry Act, R.S.A. 1970 , c. 270

The Partnership Act, R.S.A. 1970, c. 271

The Pension Benefits Act, R.S.A. 1970 , c. 272

\section{Action or Remedy}

s. 17(1)-A member of the Guild desiring to contest the validity of an election may present a petition to the Supreme Court of Alberta asking that the election be set aside within ...

s. 43(1)-A prosecution under this Act or the regulations must be commenced within ...

s. 9(1)-A member of the Association may dispute the validity of an election by petition to the Supreme Court which must be filed within...

s. 15(1)-The Registrar of the Association shall issue a certificate of registration to a member of the Association within ...

8. 24(2)-A member charged with an offence under this Act shall be given at least...

s. 30(1)-A member found guilty of conduct unbecoming an optometrist may appeal to the Supreme Court of Alberta by originating notice of motion from the finding of guilt or from an order made under 8. 17 within ...

8. 34-A member may be suspended with. out notice if he is in default of payment of monies owing by him to the Association where the default in payment is for a period of at least ...

s. 84(1)-A declaration referred to in s. 81 shall be filed

(a) within ...

(b) if a fiat is obtained from a judge of the Supreme Court or the district court having jurisdiction in the district where the partnership carries on business ...

8. 85(2)-A declaration of use of a trade name under $\mathrm{s} .85$ shall be filed

(i) within ...

(ii) if a fiat is obtained from a judge of the Supreme Court or from a judge having jurisdiction in the district court of the district where the declarant carries on business ...

8. 19(1)-An employer may serve a written notice of objection in duplicate against a refusal of registration or cancellation of a certificate of registration within ...
Limitation Period

30 days of the election date.

1 year from the date the alleged offence was committed.

30 days of the date of the election.

14 days after the filing of the certificate of approval for registration.

10 days notice of the time, date and place of the meeting of the dis. cipline committee for the hearing of the charge.

30 days of the date that the member was served with a copy of the council's findings and the order, if any, made under 8.17.

60 days.

6 months after the formation of the partnership, or

at any time.

6 months of the time when the business name is first used, or

at any time.

60 days of the day of mailing of notification of refusal or cancellation or registration. 
Statute

\section{Action or Remedy}

s. 20(1)-Upon serving a notice of objection under s. 19, an employer may appeal to the Appellate Division of the Supreme Court for an order requiring the Superintendent to accept the pension plan for registration

(a) within ...

(b) after...

The Perpetuities Act, 1972, c. 121

The Petty Trespass Act, R.S.A. 1970, c. 273

The Pharmaceutical Association Act, R.S.A. 1970 , c. 274 s. 18(1)-In the case of a contract whereby for valuable consideration an interest in real or personal property may be acquired at a future time, the perpetuity period is...

s. 19(2)-The perpetuity period for the purpose of a possibility of reverter or a possibility of a resulting trust or of a right of re-entry on breach of a condition subsequent or equivalent right in personal property is . .

s. 20(1)-A specific non-charitable trust may be valid so long as and to the extent that it is exercised either by the original trustee or his successor pursuant to the conditions of this subsection, within a period of ...

s. 20(2)-Persons and their successors who would have been entitled to the property comprised in a trust for a specific noncharitable purpose are entitled where the income and capital of such trust is not fully expended within a period of ...

s. 6-No person shall be prosecuted under this Act except ...

s. 23(2)-Notice in writing of the intention to make an inquiry to the member whose conduct is being investigated, shall be given in accordance with this section by the Registrar to the member at least ...

\section{Limitation Period}

90 days after the Superintendent has confirmed its upinion that the pension plan is not acceptable for registration, or

90 days and before 180 days have elapsed after the service of the notice of objection and the Superintendent has not notified the employer that he has confirmed or varied his opinion.

80 years from the date of the contract, and if the contract provides for the acquisition of such an interest at a time greater than 80 years, then the interest may be acquired up to 80 years and not thereafter.

40 years.

21 years, notwithstanding that the disposition creating the trust manifested an intention either expressly or by implication that the trust should or might continue for a period in excess of that period.

21 years.

upon an information laid by the owner or occupier of land, or his servant.

14 days prior to the date of the investigation. 
Statute

The Pipe Line Act, R.S.A. 1970, c. 275

The Planning Act,

R.S.A. 1970, c. 276

Amended by 1971 ,

c. 84

R.S.A. 1970 , c. 276

1971, c. 84

Amended by

1973 , c. 43

R.S.A. 1970, c. 276

\section{Action or Remedy}

s. 24(2)-The investigating committee may suspend the member whose conduct is the subject of investigation until ...

s. 26(1)-A person whose name has been ordered to be erased from the register or who has been suspended by order may appeal to a judge of the Supreme Court in chambers at any time within ...

8. 26(3)-The appeal may be by notice of motion, which shall be served upon the registrar within ...

s. 13(2)-The permittee of a flow line constructed under this Act shall forward to the department a sketch in duplicate showing the route of the flow line coloured in red within ...

8. 21(2)-Where in the opinion of the Minister, a condition exists that is a danger to any person or to public or private property the Minister shall not cancel a licence under subsection (1) until he has given the licensee...

8. 6(3)-An order of the Board pursuant to subsection (2) is void unless it is acted upon within ...

s. 19(3)-Where an application is refused, another application for approval of a proposed subdivision for the same land, and for the same use of land, may not be made by the same or any other person until at least ...

s. 20(1)-Where an application is refused for any reason other than a failure to comply with an existing general plan, preliminary regional plan, regional plan, etc. or is approved conditionally, the applicant may appeal to the Board by serving a written notice of appeal on the secretary of the Board within ...

8. 20(2)-An application to subdivide shall be deemed to be refused

(a) in the case of land situated adjacent to bodies of water, when a decision thereon is not made within . . .

(b) in all other cases when a decision thereon is not made within ...

s. 20(5)-In determining an appeal, the Board is not bound by the subdivision and transfer regulations and shall render its decision by an order within ...

\section{Limitation Period}

the next meeting of the council or for a period of three months, which. ever period is the shorter.

30 days after the date of the order.

the time limited for appeal under subsection (1). (see above)

60 days of the date the flow line is placed in operation.

30 days notice to rectify his default.

12 months of the date of the refusal.

6 months after the date of the refusal.

30 days after the date upon which notice of the decision is mailed to him.

\section{0 days, or}

60 days, after the receipt of the application in its completed and final form by the approving authority.

60 days from the date on which the hearing is held. 
Statute

1971, c. 84

R.S.A. 1970 , c. 276

\section{Action or Remedy}

s. 22(1)-When an application for a proposed subdivision has been approved, the applicant shall submit to the proper approving authority, a plan of subdivision or a registerable instrument drawn in conformity with the approved application within ...

s. 22(2)-The application of a plan of subdivision or registerable instrument is void if the plan of subdivision or registerable instrument is not submitted within...

s. 24(3)-Section 20 and the limitation periods contained therein apply to an application for approval under this section.

s. 26.2(3)-A person claiming to be affected by the proposed disposition of the reserve shall serve written notice of his objection to the municipal secretary prior to ...

s. 37(1)-The council shall either

(a) discontinue a replotting scheme, or

(b) proceed with the scheme by submitting documents to the Public Utilities Board in accordance with this subsection not later than ...

s. $38(1)-A$ person who at the time the council submits a scheme to the Public Utilities Board, has a registered interest in any land affected by the replotting scheme, and has not previously consented to the replotting scheme, may apply for and shall receive such compensation as the Board fixes not later than ...

s. 38(2)-Where land affected by a replotting scheme is redistributed as provided by section $32(4)$, the council shall serve notice by mail on the registered owners who have not consented to the scheme, and they may apply for and shall receive such compensation as the Board fixes, not later than ...

s. 39-Where a council has submitted the documents specified in section $37(1)(b)$ and where a person has applied for compensation pursuant to section 38 , the Public Utilities Board shall fix a time and place for the hearing of applications for compensation and shall cause notice in writing to be sent to those persons not later than ...

8. 44(1)-The council may by resolution adopt a replotting scheme if no applications for compensation are made within...

\section{Limitation Period}

12 months after the date of approval or within such longer period not exceeding 12 months ats the approving authority may allow.

12 months after the date of approval of the application, or within such longer period of time as the approving authority has allowed.

the day on which the hearing is proposed to be held.

6 months after the filing of a resolution approving a replotting scheme that has been consented to by less than $90 \%$ of the owners of the lands affected by the scheme.

3 months after notice is served pursuant to section 37.

3 months after notice is served.

30 days before the date fixed for the hearing.

the time limited by section 38 (i.e., 3 months after notice served pursuant to section 37 ). 
Statute

\section{Action or Remedy}

8. 45(3)-The council shall pass and file in the land titles office a resolution dis. continuing a replotting scheme, and the Registrar shall cancel all replotting notices upon the certificates of title to those parcels to which the resolution applies, if the council does not adopt the scheme within...

8. $75(2)(c)-N o t i c e$ of an intended confir. mation of the proposed regional plan shall state that representations by property owners and other interested persons will be heard by the commission upon a date to be stated in the notice, not less than ...

s. 87(3)-The Board, in its sole discretion, may refuse to entertain an appeal that has not been lodged with the secretary of the Board within ...

8. 88(2)-The Board shall give notice in writing to all public authorities that it thinks are concerned with the subject matter of the appeal at least ...

8. 94(4)-The Board shall give notice in writing to the council of any municipality that it thinks is concerned stating the time and place of the inquiry referred to in subsection (3) at least ...

8. 104(2)-A development control by-law may provide that when an application for a development permit is refused, another application for a permit on the same parcel of land or for the same or similar use of land may not be made by the same or any other applicant until at least ...

8. 104(4)-The permit for a development ceases to be valid, if the development authorized by the permit is not commenced within ...

8. 110-A person affected by the decision of a development officer or a municipal planning commission made under a development control by-law may appeal to the development appeal board as provided in section 128; that is within ...

8. 124(2)-A zoning by-law may provide that when an application for a development permit is refused, another application for a permit on the same parcel of land and for the same or similar use of land may not be submitted by the same or any other applicant until at least...

8. $126(2)-$ A notice from the council regarding unauthorized construction shall state that removal, demolition or alteration to the building shall be carried out or effected within a reasonable period stated in the notice which shall not be more than...

\section{Limitation Period}

6 months after the date of determination of any compensation to be paid under s. 42.

30 days from the date of the first publication of the notice.

60 days of the date of the decision or action that is the subject of an appeal.

10 days before the date set for the hearing.

10 days before the date set for the inquiry.

6 months after the date of the refusal.

12 months from the date of its issue.

14 days after notice of the decision is mailed or posted on the site of the proposed development or published in a newspaper circulating in the area per subsection (1). per 1973 , c. 43 , s. 11.

6 months after the date of the previous refusal.

2 months computed from the date of the notice. 


\section{Statute}

Amended by 1973, c. 43

R.S.A. 1970 , c. 276

The Podiatry Act, R.S.A. 1970 , c. 277

\section{Action or Remedy}

s. 128(1)-An aggrieved person may appeal the decision of a development officer or municipal planning commission by serving written notice of appeal on the secretary of the development appeal board within...

8. 128(3)-An application for a development permit shall, at the option of the applicant, be deemed to be refused when the decision by the development officer or the municipal planning commission thereon is not made within ...

8. $128(4)(a)$-The development appeal board shall hold a hearing within ...

s. $128(4)(b)-T h e$ development appeal board shall ensure that notice of the hearing is mailed to the appellant and to all assessed owners of land who, in the board's opinion, are affected at least ...

8. $128(6)(b)$-In determining an appeal a development appeal board shall render its decision in writing to the appellant within ...

s. 128(7)-A decision of the development appeal board is final and binding on all parties and all persons subject only to appeal under section 146 and is valid for a period of ...

s. $137(5)(a)-N o t i c e$ in writing of intention to make an application under this section shall be given to the occupier of the property where service of the notice is made personally at least . . .

8. $137(5)(b)-$ Where the notice is served by registered mail, there shall not be less than ...

8. 146(2)-Leave to appeal pursuant to subsection (1) shall be obtained from a judge of the Appellate Division upon application made within ...

8. 146(3)-Upon leave to appeal being obtained, the party appealing shall give to the parties affected by the appeal or their counsel and to the secretary of the tribunals affected, notice in writing that the case has been set down for appeal within...

8. 13(1)-Any member who has been expelled or suspended from the Association may appeal from the order of the Council to a judge of the Supreme Court in cham bers at any time within ...

\section{Limitation Period}

14 days after notice of the decision is mailed or posted on the site of the proposed development or published in a news. paper circulating in the area. (Note qualification in subsection (2).)

40 days after receipt of the application in its complete and final form, and the applicant may appeal in writing to the development appeal board as provided in subsection (1) as though he had received a refusal at the end of the periods specified in this subsec. tion.

40 days from the receipt by it of the letter of appeal.

7 days (exclusive of Saturday, Sunday and other holidays) prior to the date of the hearing.

60 days from the date on which the hearing is held.

12 months from the date of its issue.

2 clear days between the service of the notice and the day of hearing.

7 clear days between the date of mailing and the date of hearing.

30 days after the making of the order or decision of the tribunal sought to be appealed from.

10 days after the appeal has been set down.

14 days of the date of the order of expulsion or suspension, or within such further time as a judge of the Supreme Court may order. 
Statute

The Police Act, 1973 , c. 44

The Possessory Liens Act, R.S.A. 1970, c. 279

The Prearranged Funeral Services Act, R.S.A. 1970, c. 281

\section{The Private}

Investigators And Security Guards Act, R.S.A. 1970 , c. 283

Amended by 1973 , c. 45
Alberta Property Tax Reduction Act, 1973, c. 46

\section{Action or Remedy}

s. 19(1)-A prosecution under this Act shall not be instituted unless it is commenced within ...

s. 33(5)-The complainant may file with the secretary of the board a notice of appeal setting forth the grounds of appeal within ...

8. 10(1)(a)-A notice to the debtor of goods held in possession of a possessory lien holder may be served by registered mail or personal service if the debts and storage charges, if any, are unpaid at the expiration of ...

8. 10(3)-The day fixed for the application to a judge for leave to sell the goods and chattels pursuant to subsection (2) shall be not less than ...

s. 17(2)-Things seized pursuant to subsection (1) shall forthwith be returned to the person being investigated if no prosecution is instituted against such person within ...

8. 15(2)-The provisions of section 15 relating to enforcement of security do not apply to any action commenced more than ...

s. 11(1)-A licencee may submit a request in writing to the Administrator requesting that a decision of suspension or refusal to issue a licence be reviewed within ...

8. 11(2)-The Administrator shall consider the additional information provided and shall notify the applicant or licencee of his decision in writing by registered mail stating the reasons therefor and advising the applicant or licencee of his right of appeal to the Law Enforcement Appeal Board within ...

8. 11(4)-A person may appeal the decision of the Administrator to the Law Enforcement Appeal Board by serving notice of appeal upon the Administrator and upon the secretary of the Board not later than...

8. 11(5)-The Board may, before or after the expiration of the time for service of the notice of appeal, extend the time for service of such notice for a further period not exceeding ...

s. 10(2)-An application for a homeowner education tax refund in respect of an eligible residence for any year

(a) may be made at any time...

\section{Limitation Period}

1 year from the date the alleged offence was committed.

30 days after receipt of the information referred to in subsection (4).

3 months in the case of a motor vehicle and 6 months in the case of any other property from the time when the relation of creditor or debtor arose with respect to the alteration or repair or the bailment of the property.

30 days after the date of mailing or serving the notice referred to in sub. section (1).

30 days after the date of a seizure under sub. section (1).

2 years after the expiration or cancellation of the licence to which the security relates.

15 days from receipt of the notification of the Minister's decision.

30 days after receiving the request for a review.

15 days after the time the appellant receives notification of the Adminis trator's decision.

30 days from the date upon which the time limit for service under subsection (4) expires or would have expired.

after municipal taxes have been levied by the local authority in that year; and 
Statute

The Psychiatric

Nurses Association Act, R.S.A. 1970, c. 289

The Psychiatric Nursing Training Act, R.S.A. 1970, c. 290

The Psychologists Act, R.S.A. 1970, c. 291

The Public Health Act, R.S.A. 1970, c. 294

The Public Highways Development Act, R.S.A. 1970 , c. 295

\section{Action or Remedy}

(b) shall be made not later than...

s. 10(3)(a)-An application for a homeowner education tax refund in respect of an eligible mobile unit for any year may be made any time after the owner has occupied the mobile unit as his normal place of residence for at least ...

8. 23(2)-A prosecution for an offence under this section may be commenced within ...

8. 15(1)-A member of the Association who has been expelled or suspended from the Association may appeal from the order of the council to a judge of the Supreme Court of Alberta, at any time within...

s. 20(2)-A prosecution for an offence under this Act may be commenced within...

8. 5(2)-A person whose certificate is ordered cancelled pursuant to subsection (1) may appeal on originating notice to the Supreme Court within...

s. 5(3)-A person appealing against an order of the committe shall serve notice of the appeal upon the chairman of the com. mittee within ...

8. 21(2)-A psychologist whose registration has been suspended or cancelled for unprofessional conduct or incompetency may appeal to the Supreme Court from the finding of guilt or the order of punishment or both by originating notice of motion filed within ...

8. 26-A prosecution for an offence under this Act may be commenced within ...

s. 28(2)-The local board, when they have appointed a Medical officer of Health for their district shall advise the Deputy Minister of the appointee's name within...

s. 27(2)-The owner of buildings which are dangerous or unslightly may be ordered to remedy the condition of the buildings or to demolish or remove the buildings within ...

s. 31(4)-A claim for compensation for the removal of wrongly placed signs shall be made by filing the claim in the office of the Minister not later than ...

\section{Limitation Period}

the close of business on the last business day of the local authority in the month of March in the following year.

120 days in that year but not later than the close of business on the last business day of the local authority in the month of March in the follow. ing year.

3 years of the commission of the offence but not thereafter.

14 days of the date of the order of expulsion or suspension, or within such further time as a judge of the Supreme Court may order.

1 year from the date of the commission of the offence, but not thereafter.

30 days of the service on him of notice of the order or within such further time as a judge of the Supreme Court may order.

the time limited for appeal under subsection (2).

30 days from the date on which the finding and order, if any, is made by the council.

2 years from the date of the commission of the offence, but not thereafter.

3 days of the making of the appointment.

60 days from the date of the making of the order.

1 year from the date of service of the notice requiring the removal of the signs. 
Statute

The Public Lands Act, R.S.A. 1970, c. 297

The Public Service Act, R.S.A. 1970, c. 298

The Public Service Pension Act, R.S.A. 1970 , c. 299

The Public Service Vehicles Act, R.S.A. 1970 , c. 300

The Public Trustee Act, R.S.A. 1970, c. 301

The Public Utilities Act, R.S.A. 1970, c. 302

\section{Action or Remedy}

8. 79(1)-The Minister may cancel a lease or withdraw any part of the land contained in a lease in accordance with the provisions of this section...

8. 27(1)-The Government or the Association may give notice to the other party to commence negotiations not less than ...

8. 30-The Executive Council and the Association shall each advise the other whether the recommendations are in whole or in part accepted or rejected within ...

8. 22-The Board shall notify an employee in writing as to the normal and alternative pensions from which the employee may make a selection not less than ...

8. 20(5)-The insurer or the guarantor under $a$ bond shall notify the Board of any impending cancellation or termination at least ...

in the absence of any such notice, the policy or bond remain in full force and effect until ...

8. 26(1)-The Board may for cause suspend a certificate and also alter or amend the certificate after giving at least ...

8. 26(2)-If in the opinion of the Board the holder of a public service vehicle certificate has not given convenient, efficient and sufficient service, the Board can cancel or revoke his certificate or grant a certificate to some other owner for the operation of the same route after allowing him reasonable time to provide such service, not being less than ...

8. 28(3)-The Public Trustee shall not apply for letters of administration until the expiration of ...

8. 28(5)-Where a grant of letters of administration has been made to the Public Trustee a new grant may be made upon application of a person otherwise entitled to letters of administration where he has given ...

8. $62(2)$-Leave to appeal to the Supreme Court of Alberta, Appellate Division, on question of law or jurisdiction must be obtained within ...

8. $63(2)-$ The party appealing shall give to the parties affected by the appeal or their solicitor and to the secretary of the Board notice in writing that the case has been set down to be heard on appeal within ...

\section{Limitation Period}

1 month after the date upon which he mailed a notice in writing to the last known address of the lessee.

60 days and not more than 90 days immediate. ly preceding the expiry of an agreement.

14 days of the receipt of the report of the negotiating committee.

90 days before an employee attains the age of 65.

15 days before the date of a cancellation or expiration of any insurance policy or bond required under this Act.

15 days' notice has been given.

10 days' notice to the holder.

10 days.

1 month from the mailing of the notice of intention to apply for letters of administration.

14 days notice in writing.

1 month of the Board order appealed from.

10 days after the appeal has been set down. 


\section{Statute}

The Public.Works Act, R.S.A. 1970, c. 303

The Quarries

Regulation Act,

R.S.A. 1970, c. 305

The Railway Act, R.S.A. 1955, c. 276

Amended by 1966 , c. 49

The Real Estate Agents Act, R.S.A. 1970, c. 311

The Reciprocal Enforcement of Judgments Act, R.S.A. 1970 , c. 312

\section{Action or Remedy}

8. $14(2)(a)-W h e r e$ a person provides labour, equipment, materials or services used in the performance of a contract with the Crown for the construction, alteration, demolition, repair or maintenance of a public work, and the contractor or a subcontractor does not pay that person in accordance with his obligation to do so, the person may send a notice of his claim to the department, board, commission or agency of the Crown that is responsible for the public work and the notice of claim shall be sent not sooner than ...

8. 12(b)-When loss of life or serious personal injury occurs in or about a quarry, the owner or manager shall send a full report thereof to the Director of Mines within ...

8. 11(3)-A notice of a meeting regarding the increase of capital stock shall be delivered to each shareholder at least ...

8. 38-Notice upon any call upon shareholders of the company shall be published by advertisement once in the Alberta Gazette at least...

8. 91(1)-Notice of the application for approval for additional lands shall be given to the owner or possessor of the lands at least ...

8. 119(1)-An appeal from an award of compensation for the expropriation of land must be brought within ...

8. 204(1)-An action for indemnity for any damages or injury sustained by reason of the construction or operation of a railway must be brought within ...

8. 14(2)-Proceedings in respect of a bond may be brought within, but not after ...

8. 36-A prosecution under this Act may be commenced within ...

8. 3(1)-A judgment obtained in a reciprocating jurisdiction must be registered in Alberta within ...

8. 7(1)-Where a judgment is registered pursuant to an ex parte order notice of the registration shall be served upon the judgment debtor within ...

and the judgment debtor may apply to the registering court to have the registration set aside within ...

\section{Limitation Period}

30 days, no later than 90 days after the last day on which the labour, equipment, material or ser. vices were provided.

24 hours.

20 days before the meeting.

4 weeks prior to the call.

10 days prior to the application.

1 month after receiving notice of the award.

1 year after the doing of the damage ceases.

2 years from the date of the termination of the bond.

2 years from the date on which the offence is alleged to have been committed, but not thereafter.

6 years from the date of judgment.

1 month after the registration or within such further period as the registering court may at any time order,

1 month after he has had notice of the registra. tion. 


\section{Statute}

The Registered

Dietitians Association

Act, R.S.A. 1970,

c. 315

The Registered

Nurses Act, R.S.A. 1970 , c. 317

The Religious

Societies' Lands Act,

R.S.A. 1970 , c. 319

The Rural Electrifi-

cation Long Term

Financing Act, R.S.A.

1970 , c. 324

The Rural Electrification Revolving Fund Act, R.S.A. 1970, c. 324

The School Act, R.S.A. 1970 , c. 329 , as amended by 1971 , c. $100 ; 1972$, c. 84 and 1973 , c. 53

\section{Action or Remedy}

8. 18(1)-Any member who has been expelled or suspended from the association may appeal to a judge of the Supreme Court of Alberta at any time within...

s. 23-A prosecution for an offence under this Act may be commenced within ...

8. 10(1)-Where a member is suspended or expelled from membership in the Association or otherwise disciplined, the member may appeal to the Supreme Court of Alberta within...

8. 13(6)-A prosecution under this Act may not be commenced after...

s. 3-The trustees shall cause the title to the land described therein to be registered in the land titles office within ...

8. 16(1)-The Director, when he has approved a loan, shall cause a notice of the lien note to be filed in the land titles office within ...

8. 17(1)-Where the Director of Co-operative Activities approves a loan he shall cause a notice of the lien note to be filed in the land titles office within ...

8. 4(3)-The petitioners of a petition filed with the board may, in the event of the secretary declaring the petition to be insufficient, appeal to a judge for an order declaring the petition sufficient within ...

8. 41(2)-Where a special meeting of a board is called, the notice of the meeting shall be delivered to each trustee at least...

8. 78(1)-A board may terminate a contract of employment with a teacher after giving the teacher...

8. 79(3)-A teacher who is suspended by a board may appeal to the Minister within ...

s. 79(4)-The Minister shall refer the appeal to the Board of Reference who shall investigate the matter and confirm or reverse the decision of the board and inform the board and the teacher of its decision within...

8. 80(1)-A teacher may terminate a contract of employment with a board after giving the board ...

8. 81-Subject to section $77(2)$ no notice of termination of a contract of employment may be given by a board or a teacher in the...

\section{Limitation Period}

14 days of the date of the order of expulsion or suspension, or within such further time as a judge of the Supreme Court may order.

2 years from the date of the commission of the offence, but not there. after.

30 days or such further time as a judge allows.

12 months of the date of the alleged offence.

12 months after the execution of the transfer or deed of conveyance.

30 days after the loan is approved.

30 days after the loan is approved.

14 days of the secretary's declaration.

6 clear days before the meeting.

30 days notice in writing of its intention to do so.

14 days after receiving the notice of suspension.

10 days of the conclu. sion of its investigation.

30 days notice in writing of his intention.

30 days preceding, or during, a vacation period of 14 or more days duration. 
Statute

The School Election Act, R.S.A. 1970, c. 331

The Alberta School Trustees' Association Act, R.S.A. 1970, c. 332

The Securities Act, R.S.A. 1970, c. 333

\section{Action or Remedy}

8. 86(2)-The board or teacher appealing to the Board of Reference shall send the notice of appeal and $\$ 50.00$ to the Minister as well as a copy of the notice of appeal to the other party within ..

s. 121(1)-A board shall submit to each municipality its requisition for that portion of its estimate that is required to be raised by the municipality within ...

s. 91(3)-A board which purchases or enters into an agreement to purchase any land or interest in land shall notify the Minister within ...

s. $116(3)$-An application pursuant to this section by a candidate who is dissatisfied with the result of the voting may be made by him only during the ...

8. 122(1)-An elector may apply to the district court by notice of motion for a recount at any time within...

s. 123-A copy of the notice of motion and the affidavit filed shall be served by the elector on the secretary of the board, the returning officer and all candidates at least ...

8. 134-The limitations contained in section 122 and 133 apply mutatis mutandis to a recount of the vote for and against a by-law or question.

s. 8-A board may exclude itself from mem bership in the association for the next following year by giving a notice in writing to the secretary-treasurer of the association not less than ...

8. 8-The Director may suspend any registration without giving the registrant an opportunity to be heard, in which case he shall forthwith notify the registrant of the suspension and of a hearing and review to be held before the Commission within ...

s. 28(1)-Any person or company affected by a direction, decision, order or ruling of the Director may request and be entitled to a hearing and review by the Commission by sending notice in writing to the Registrar within ...

8. 29(2)-Every appeal to the Appellate Division shall be by notice of motion sent to the Registrar within ...

8. 40(2)-Where a material adverse change occurs after the date of the preliminary prospectus and before the issuance of a receipt for a prospectus that makes untrue or misleading any statement of a material fact, an amendment to the preliminary prospectus shall be filed with the Commission as soon as practicable, and in any event within ...

\section{Limitation Period}

14 days of the receipt of the notice of the examination of the contract.

30 days of the date of the purchase.

30 days of the date of the purchase.

72-hour period immediately following the closure of the polls.

15 days from the time of the declaration of the result.

3 days prior to the application being made.

2 months before the beginning of the next following financial year.

15 days of the date of the suspension.

30 days after the mailing of the notice of the direction, decision, order or ruling.

30 days after the mailing of the notice of the order.

10 days from the date the change occurs. 
Statute

Amended by 1972 , c. 85

\section{Action or Remedy}

s. 55-Where a material change occurs during the period of primary distribution to the public of a security that makes untrue or misleading any statement of a material fact contained in a prospectus filed under this Part in respect of which a receipt has been issued by the Registrar, an amendment to the prospectus shall be filed with the Commission as soon as practicable, and in any event within ...

s. 56-Where primary distribution to the public of the security is in progress 12 months from the date of the issuance of the receipt for the preliminary prospectus relating to such security, or the date of the last prospectus relating to such security, a new prospectus that complies with this Part shall be filed with theCommission and a receipt thereof obtained from the Registrar within ...

8. 65(2)-No action shall be commenced for recission of purchase after the expiration of ...

s. 70(8)-No action shall be commenced under section $70(5)$ or $70(6)$ after the expiration of ...

s. 88(3)-Where a take-over bid is made by or on behalf of a company the offeror shall file with the Commission a copy of the take-over bid and all supporting or supplementary material and every board of directors that distributes a directors' circular shall file with the Commission a copy of the directors' circular and all supporting or supplementary material within...

s. $106(3)$-Where section 101 or 102 is an application to a solicitation of proxies, the corporation concerned shall file with the Commission all forms of proxy, information circulars, notices of meetings and other communications which it sends to its shareholders within ...

s. 109(1)-A person or company that becomes an insider of a cor poration shall file with the Commission a report as of the day on which he became an insider, of his direct or indirect beneficial ownership of or control or direction over capital securities of the corporation within ...

8. 112(2)-An action to enforce any right with respect to the liability of insiders may be commenced only within ...

\section{Limitation Period}

10 days from the date the change occurs.

20 days from the expiration of the applic. able 12-month period subject to such terms as the Commission may require.

90 days from the last to occur of either the receipt of the prospectus or amended prospectus by the purchaser or the date of the contract.

3 months from the date of the service of the notice under subsections (5) or (6).

5 days after the date that copies thereof are first sent to the offerees.

5 days after the date that they are first mailed or required to be mailed by the corporation to its shareholders whichever comes first.

10 days after the end of the month in which he becomes an insider.

2 years after the date of completion of the transaction that gave rise to the cause of action. 
Statute

Amended by 1972 ,

c. 85

\section{Action or Remedy}

8. 113-Upon application by any person or company referred in section $112(1)$, a judge of the Supreme Court may make an order requiring the Commission to commence or continue an action in the name of or on behalf of the corporation to enforce the liability created by section 112 if satisfied that such person or company has reasonable grounds for believing that the corporation has a cause of action and either the corporation has failed to prosecute diligently an action commenced by it under section 112 , or the corporation has refused or failed to commence an action under section 112 within ...

s. 119(1)-A corporation shall file with the Commission, comparative financial statements within ...

8. $129(1)-A$ corporation shall file with the Commission a copy of a comparative interim financial statement for the 6 month period that commenced on the date of incorporation or if the corporation has completed a financial year, for the 6 month period commenced immediately after the end of the last completed financial year and for the comparative 6 month period, if any, in the 12-months immediately preceding the commencement of the 6 month period in respect of which such interim financial statement is issued within...

8. 130(4)-Where a corporation complies with this Part, the financial statements and the auditor's reports thereon, the interim financial statement and the additional financial information referred to in 8 . 130 (1) clauses (a) and (b) shall be filed with the Commisgion within ...

or within ...

8. 137(2)-No prosecution under this Act shall be commenced more than ...

8. 137(3)-Subject to subsection (2), no proceedings under this Act shall be commenced more than ...

\section{Limitation Period}

60 days after receipt of a written request from such person or company to do 80.

170 days of the date of which it is made up.

60 days of the date to which it is made up.

5 days after such financial statements are mailed by the corporation to its shareholders;

170 days of the date which such financial statements are made up or, in the case of interim financial statements, within 60 days of the date to which the interim financial statements are made up, which ever is earlier.

1 year after the facts upon which the prosecution was based first came to the knowledge of the Commission.

2 years after the facts upon which the proceedings are based first came to the knowledge of the Commission. 
Statute

The Seed-Control Areas Act, R.S.A. 1970, c. 335

The Seizures Act, R.S.A. 1970, c. 338

The Senior Citizens Shelter Assistance Act, 1972 , c. 86

\section{Action or Remedy}

8. 147(2)-Where an order compelling compliance is sought under section 147(1) the originating notice shall be served at least ...

8. 148(2)-A bond may be cancelled by any person bound thereunder by giving to the Registrar at least ...

8. 148(3)-For the purposes of every act and omission occurring during the period of registration or the period prior to cancellation, every bond continues in force and the collateral security, if any, shall remain on deposit for a period of ...

8. 3(3)-Where a meeting of the occupiers of land is being called, a notice shall be posted at each post office serving the area and at any two other conspicuous public places in the area and in at least one issue of a newspaper published in the Province circulating within the area at least ...

s. 9(2)-If a person fails to comply with section $9(1)$ the committee with the approval of the Field Crops Commissioner may give that person a notice in writing requiring him to take action to prevent the blossoming or maturing of the prohibited seed or crop within ...

8. 7(11)-The sheriff shall sell any shares in a private company in the same manner as any other personal property where they remain unsold at the expiration of ...

8. 27(1)-The person liable for the payment of the debt for which the seizure is made, if he objects to the removal and sale of the goods seized, shall sign the notice of objection and deliver it to the sheriff within ...

8. 30(3)-Where the creditor makes the sale under section $30(1)(b)$ he shall file with the sheriff of the judicial district in which the seizure was made a statutory declaration setting out the particulars of the sale, the amount realized by the sale and the necessary and proper disbursements and fees in connection with the sale within ...

8. 40(1)-A sheriff in his discretion may, at any time after a seizure under writ of execution or distress warrant has been in effect for 6 months, serve upon the party who instructed the seizures, or all persons having subsisting writs of execution in his hands, a notice in writing informing each person so served that he intends to release the seizure upon the expiration of a period of ...

s. 15(2)-A prosecution for an offence under this section may be commenced within...

\section{Limitation Period}

2 clear days before the day named in the notice for hearing the application.

3 months notice in writing of the intention to cancel.

2 years after the lapse or cancellation of the registration to which it relates, or the cancella. tion of the bond, which. ever occurs first.

15 days before the day named for the meeting.

7 days of the receipt of the notice.

30 days.

14 days of the date of the seizure.

30 days after the sale.

60 days from the date of service of the notice.

3 years of the commis. sion of the offence but not thereafter. 


\section{Statute}

'I'he Sheriffs Act, K.S.A. 1971), c. 342

The Small Claims Act, R.S.A. 1970, c. 343

The Social Workers Act, R.S.A. 1970, c. 346

The Societies Act, R.S.A. 1970, c. 347

The Soldiers' Relief Act, R.S.A. 1942, c. 146

\section{Action or Remedy}

s. 10(1)-If a bond is approved it shall, together with all affidavits, be forthwith deposited in the office of the Provincial Secretary and notice of the approval shall be given to the sheriff, deputy sheriff, assistant sheriff or bailiff, but if the bond is disapproved the sheriff, deputy sheriff, assistant sheriff or bailiff shall, furnish and transmit another bond, in duplicate and in lieu of the bond so disapproved to the satisfaction of the Attorney General within ...

8. 15-A person who has become surety for a sheriff, deputy sheriff, assistant sheriff or bailiff and is no longer disposed to continue the responsibility may give notice thereof to the sheriff and to the Attorney General and in such case the sheriff shall complete and transmit to the Attorney General the necessary bonds and affidavits in that behalf within ...

s. 9(1)-The date fixed by the summons for trial shall not be more than ...

s. 9(2)-Notwithstanding subsection (1), a summons shall be served at least ...

s. 10(2)-A magistrate may adjourn the trial when a defendant asserts a counterclaim and the plaintiff has not been served with a copy of a statement of particulars at least ...

s. 34(1)-Where an appeal is taken, the appellant shall cause the notice of appeal to be served within ...

s. 34(2)-The district court may, upon application made before or after the expiration of the periods fixed by subsection (1) fix a further period within which the service and filing may be effected, such period not exceeding ...

8. 18(3)-No prosecution under this Act shall be commenced after...

8. 8(3)-An appeal may be taken to the Lieutenant Governor in Council from a decision given by the Registrar under the provisions of this section within ...

s. 25-A society shall hold in the Province an annual general meeting, and shall file with the Registrar a statement in form of a balance sheet within ...

s. 35-The provisions of The Companies Act relating to the winding-up of companies apply mutatis mutandis to a society under this Act.

8. 16-The Limitation of Actions Act shall not run in favour of any person entitled to the benefit of this Act during the period within which such person is receiving such benefit.

\section{Limitation Period}

1 month thereafter.

1 month after the notice.

60 days from the date of the issue of the sum. mons.

10 days before the date appointed therein for trial.

6 days before the date fixed for the trial.

30 days after the judg. ment was pronounced.

30 days from the date of the extending order.

4 years after the date of the alleged offence.

1 month of the date of the decision.

14 days after each annual meeting. 
Statute

The Soil Conservation Act, R.S.A. 1970, c. 348

The Students Loan Guarantee Act, R.S.A. 1970, c. 354

The Surface Reclamation Act, R.S.A. 1970 , c. 356

The Surface Rights Act, 1972, c. 91

The Surrogate Courts Act, R.S.A. 1970 , c. 357

\section{Action or Remedy}

8. 7(1)-Any person who owns occupies or controls land affected by a notice given by an officer pursuant to this Act and who is aggrieved by the notice, may appeal therefrom to the appeal committee of the municipality within ...

s. 10(2)-A prosecution for an offence may be instituted at any time within ...

8. 26(1)-An appellant shall file a notice of appeal with the clerk of the district court within ...

8. 28-The appellant shall serve a copy of the notice of appeal upon the secretary within ...

8. 34(1)-The appellant shall file a notice of appeal regarding the reclamation certificate with the clerk of the district court before the expiration of ...

8. 35-The appellant shall serve a copy of the notice of appeal upon the secretary within ...

8. 17(2)-A notice of the hearing of an application relating to lands of the Crown in right of Alberta, shall be given in writing to the Deputy Minister of the Department charged with the administration of the land, and when the title for the land shows that another Department has an interest in the lands, to the Deputy Minister of that Department, at least...

s. $18(1)-N o t w i t h s t a n d i n g ~ s e c t i o n ~ 17$, after the filing of an application the Board may issue an order granting right of entry in respect of the surface of the land upon the operator filing with the Board a letter of consent signed by the respondent, or after...

or...

8. 24(4)-The party appealing from a compensation order shall cause a notice of appeal to be filed in the office of the clerk of the district court within ...

and shall serve the Board and the other parties to the compensation order appealed from or their respective solicitors with a copy thereof not later than ...

s. 22(4)-The notice of an appeal under this section shall be given within ...

\section{Limitation Period}

the time fixed by the order of the officer for carrying out the recommended soil conservation practice and not afterward.

3 years of the commission of the offence but not thereafter.

30 days of the date of mailing to him of the invoice for the expenses paid.

10 days of filing the notice of appeal.

1 year from the date of the mailing of a copy of the reclamation certificate.

20 days of filing the notice of appeal.

5 days before the hearing of the application.

7 clear days have elapsed from the date of personal service;

14 days from the date of any substituted service on the respondent of $a$ copy of the application and a notice in Form B in the Schedule.

30 days after the date of the compensation order;

10 days after the filing of the notice of appeal.

30 days (but the 30 day period may be extended by a judge of the Appellate Division either before or after it has expired). 


\section{Statute}

The Tax Recovery Act, 1922, R.S.A. 1942 , c. 162

The Tax Recovery Act, R.S.A. 1970, c. 360

Teachers' Retirement Fund Act, R.S.A. 1970 , c. 361

\section{Action or Remedy}

s. 29-No action, suit or proceedings for the return by a municipality of any moneys paid to it under protest or otherwise, on account of a claim, whether valid or invalid, made by the municipality for taxes shall be commenced after the expiration of ...

s. $26(1)-A$ person interested in any parcel of land may apply in chambers to a judge of the district court of the judicial district in which the parcel is situated at any time prior...

s. 26(2)-Where a judge is of the opinion that the provisions of this Act have not been complied with, he may grant an order staying the issue of any certificate of title with respect to the parcel or the sale of the parcel as the case may be, until the respective rights of the applicant and of the municipality have been determined by a declaratory order or until after the expira. tion of a period of ...

8. 26(3)-The order ceases to be of any effect and no further order shall be made if the rights of the applicant and of the municipality are not determined prior to the expiry of ...

s. 28(2)-Moneys paid into the tax sale trust account shall be paid out to the person or persons who apply therefor, or are declared by the district court judge to be entitled to the surplus moneys where such persons apply to a district court within ...

8. $30(1)-$ No action, suit or other proceedings for the return of moneys paid to the municipality shall be commenced after the expiration of ...

s. 30(2)-The payment made to the municipality shall be deemed to have been a a voluntary payment after the expiration of ...

8. 22(1)-A teacher may elect to continue to contribute to the fund where he becomes employed as a university teacher within...

s. 22(2)-The election shall be in writing and delivered to the Board within ...

\section{Limitation Period}

6 months after the payment of the moneys and after the expiration of such 6 months period without such action, the payment made to the municipality shall be deemed to have been a voluntary payment.

to the sale of any parcel or a final acquisition by the municipality which. ever event first happens.

30 days or less, as fixed by his order.

30 days from the date of the staying order, or upon the expiry of the period fixed by the order, as the case may be.

\section{0 years from}

(i) the date of final acquisition, or

(ii) the date of sale, if the parcel is sold prior to final acquisition.

6 months after payment of the moneys.

6 months without any action, suit, or other proceedings having been commenced.

3 months of his last contribution to the fund, or within such longer period as the Board, upon his written application, may approve.

1 year from the commencement of his employment as a university teacher. 
Statute

Amended by 1973 , c, 56 s. 8(a)

The Teaching

Profession Act,

R.S.A. 1970 , c. 362

The Tobacco Tax Act, R.S.A. 1970 , c. 364

The Trust Companies Act, R.S.A. 1970, c. 372

\section{Action or Remedy}

8. 24(1)-A teacher may elect to contribute to the fund where he becomes employed as an academic staff member of a public college under the Colleges Act within ...

s. 24(3)-The election shall be in writing and delivered to the Board within ...

8. 25(1)-A teacher who becomes employed in any position requiring the holding of a certificate of qualification issued under the Department of Education Act by a local of the Alberta Teachers Association shall continue to contribute to the fund from the commencement of such employment and shall be deemed to be a teacher while so employed if he makes written application to the Board within ...

s. 16(2)-Proceedings may be instituted against a former member for unprofessional conduct or unethical conduct while he was an active member, at any time within ...

s. 17(1)-An accused person shall be given at least...

8. 21(1)-A person found guilty of unprofessional or unethical conduct may appeal to the Teaching Profession Appeal Board within ...

8. 15-Any information with respect to any contravention of this Act or the regulations may be laid within...

s. 16(1)-Every company shall furnish to the Director a certified copy of every bylaw within...

8. 16(3)-The Company may appeal a decision of the Director to the Supreme Court by way of originating notice returnable within ...

s. 17(3)-Notice of the time and place of the holding of the annual general meeting shall be delivered to each common shareholder or to his attorney authorized in writing, at least...

8. 18(3)-Notice of the holding of a special general meeting of the shareholders specifying the time and place of the meeting and the business to be transacted thereat, shall be delivered to each shareholder at least ...

\section{Limitation Period}

3 months of the date of his last contribution to the fund, or within such longer period as the Board, upon his written application, may approve.

1 year from the commencement of his appoint. ment as a college aca. demic staff member.

3 months of the date of his last contribution to the fund or within such longer period as the Board may approve.

6 months from the date he ceased to be an active member, in the same manner as if he were still an active member.

10 days notice in writing of the matter to be heard and of the time and place of the hearing by the discipline com. mittee.

15 days from the date he is given notice of such finding.

3 years from the time when the matter of the information arose, and not afterwards.

30 days of the passing of approval of the by-law.

30 days after the date of service of the notice on the company and showing the Director as the respondent.

20 days before the time fixed for the holding of the meeting.

20 days before the day appointed for the meet. ing. 
8. 45(2)-A director is not liable under subsection (1) unless

(a) the company has been sued for the debt within...

or

(b) the company has, within that period gone into liquidation or has been ordered to be wound up and the claim for such debt has been filed and proved, and unless he is sued for the debt while a director or within ...

s. 73(1)-A person who becomes an insider of a provincial company shall file a report with the Commission as of the day on which he became an insider, of his direct or in direct beneficial ownership or of control or direction over capital shares of the company within ...

8. $73(2)$-Where an insider of a provincial company acquires direct or indirect beneficial ownership or control or direction over the capital shares of the company, he shall file a report of his direct or indirect beneficial ownership or control with the Commission within ...

8. 73(3)-A person who has filed or is required to file a report under this section and whose direct or indirect beneficial ownership or control or direction over capital shares of the company changes from that shown or required to be shown and such report or in the last report filed by him under the subsection, shall file a report containing the changes of his control or direction over the capital shares of the company within ...

s. 76(2)-An action to enforce any right created by subsection (1) may be commenced only within ...

s. 85(4)-The company shall file with the Director a copy of the rectification order within ...

8. 91(1)-Every company shall prepare an annual financial statement for distribution to shareholders within ...

s. 91(4)-A copy of the financial statement, the certificate made under subsection (3) and the auditors' report made under section 90 shall be mailed or delivered to every common or preferred shareholder of the company at least ...

8. 98(5)-A company maintaining a common trust fund shall file and pass an account of its dealing with respect thereto in the office of the district court of the district in which the company maintains its head office not more than ...

1 year after it has become due and execution has been returned unsatisfied in whole or in part,

1 year after he has ceased to be a director.

10 days after the end of the month in which he becomes an insider.

10 days after the end of the month in which he acquired such direct or indirect beneficial ownership or such control or direction.

10 days following the end of the month in which such change takes place, provided he was an insider of the company at any time during such month.

2 years after the date of completion of the transaction that gave rise to the cause of action.

15 days after the making thereof.

60 days after the end of its fiscal year.

20 days before the annual meeting of shareholders.

3 years after the date on which a common trust fund is established, and triennially thereafter. 
Statute

The Ultimate Heir

Act, R.S.A. 1970 , c. 376 as amended by 1973 , c. 58 s. 4

\section{Action or Remedy}

s. 153(2)-A company affected by a decision of the director entitling it to registration under subsection (1) may request a hearing and review by notice in writing served upon the Director within ...

s. 153(8)-Every appeal shall be made by way of originating notice of motion showing the Director as the respondent and shall be returnable within ...

s. 161(1)-Every registered company shall file a statement of its financial condition and affairs for the preceding fiscal year within...

s. $161(5)-O n$ sufficient cause shown and upon payment of the prescribed fee, the Director may, before the expiry of the 60 day period referred to in subsection (1), extend the time for filing the statement for an additional period not exceeding in any event ...

s. $161(7)-A$ registered provincial company shall file with the Director a certified copy of the comparative financial statements required to be prepared under section 91 , and the certificate under section 91(3) within ...

8. 161(8)-A registered extra-provincial company shall file with the Director a certified copy of its most recent financial statement prepared for distribution to its shareholders and the auditors' report there. on, within ...

s. 162(1)-Every registered provincial company shall file with the Director returns regarding deposits of investment moneys on or before ...

8. 173(2)-A company may appeal a decision of the Director regarding the disallowance and revaluation of assets to the Supreme Court by way of originating notice showing the Director as the respondent returnable .within ...

8. 204(2)-A prosecution under this Act may be commenced within ...

8. 7-The Minister of Advanced Education shall be deemed to be the sole heir and next of kin of the intestate and no action shall be brought to question the right of the Universities Commission as sole heir and next of kin of the intestate when no claim. ant has commenced an action to dispute the claim of the Universities Commission within ...

\section{Limitation Period}

30 days after the delivery of the certified copy of the decision.

30 days after the delivery of the decision under subsection (6).

60 days after the end of its fiscal year.

30 days after the expiry of that 60-day period.

5 days after copies thereof are first mailed or delivered to its share. holders.

5 days after they are first mailed or delivered to its shareholders.

the last day of January, April, July and October in each year.

30 days after the date of service of the copy of the decision on the company.

1 year after the commission of the offence, but not thereafter.

6 years from the death of the intestate. 
Statute

Alberta Uniform Building Standards Act, 1973, c. 85

The Universities Act, R.S.A. 1970 , c. 378

The Veneral Diseases Prevention Act, R.S.A. 1970 , c. 382

The Veterinary Surgeons Act, R.S.A. 1970 , c. 383

\section{Action or Remedy}

8. $9(1)(2)-$ Where an owner of a building is of the opinion that an order of an inspector made pursuant to 8.8 is not proper, that person may appeal to the Council by serving notice of the appeal on the director within ...

8. 9(5)-An appeal to the Supreme Court of Alberta pursuant to subsection (4) shall be commenced by originating notice of motion within ...

s. 50(2)-A municipality that operates a dog pound shall, upon the request of the Faculty of Medicine of the University make available to the Faculty for research and teaching purposes all pounded dogs (a) that have not been claimed by the owner within ...

8. 5(2)-The reports required of a physician, superintendent or head of a hospital or sanatorium, or a person in charge of medical services in a jail, reformatory or similar place or in an educational institution shall be completed and forwarded to the Director after the first diagnosis or knowledge of veneral disease within ...

8. 6-The person in charge of a laboratory shall report to the Director on all positive and negative tests for syphillis and all positive results of tests for gonorrhoea within...

s. 8(2)-A person who fails to attend upon his physician within 7 days of an appointment for treatment for venereal disease shall be presumed to have neglected to continue his treatment and in that case the physician shall forward the report to the Director within ... .

8. 11(2)-In any case to which subsection (1) refers, regarding the issuance of a warrant after laboratory tests are undertaken, the magistrate may refuse the information if the application is made later than ...

8. 14(1)-A member whose conduct is the subject of inquiry shall be given at least...

s. 15(1)-A person whose name has been erased from the register, or who has been suspended from practice or who has been fined, may appeal from such order to a judge of the Supreme Court of Alberta at any time within...

s. 26(2)-A prosecution for an offence under this Act shall be commenced within...

\section{Limitation Period}

15 days from the date that the owner of the building or the person responsible for the use, construction or demolition of the building is given the order of the inspector.

30 days from the date that the order of the Council is served upon the party appealing.

10 days of the impoundment.

48 hours of the first diagnosis treatment or knowledge.

48 hours of the time the results are determined.

14 days of the appoint ment.

7 days after the results of the laboratory tests are known.

2 weeks notice of the meeting of the Council for the taking of the evidence or otherwise ascertaining the facts which are the subject of the inquiry.

6 months from the date of the service of the order of the council upon him.

6 months after the date upon which the offence was committed. 


\section{Statute}

The Vital Statistics Act, R.S.A. 1970 , c. 384
The Warehouse Receipts Act, R.S.A. 1970 , c. 385

\section{Action or Remedy}

s. 3-Every person assisting in the birth of a child in the Province shall deliver to the district registrar a notice of the birth in the prescribed form within ...

s. 4(2)-The birth of every child born in the Province shall be registered within ...

8. 7(1)-A person finding a deserted new born child shall give to the district registrar of the registration district in which the child is found, such information as he may possess regarding the birth of the child within ...

8. 8(2)-No alteration of or addition to a given name shall be made under this section in any registration of a birth unless the name of the child was changed or the name was given to the child within ...

8. $13(3)$-The person by whom a marriage was solemnized shall deliver or mail a completed statement to the district Registrar of the registration district in which the marriage was solemnized within ...

8. 13(4)-The district registrar, if he is satisfied as to the truth and sufficiency of the statement regarding the marriage, shall register the marriage by signing the statement if he is in receipt of it within ...

8. 16(1)-The district registrar shall register a statement regarding the death of a person by signing such statement where he is in receipt of it within ... .

8. $35(1)-A$ judge of the district court may make an order requiring the Director to accept the application and register the birth, still birth, marriage or death where an application is made to the judge within ...

8. 35(3)-A judge of the district court may make an order requiring the Director to issue a certificate or make a search if an application therefore is made within ...

s. 35(4)-Any person interested may appeal an order of the Director made under 8.22 within ...

8. $35(5)-N o t i c e$ of the application or appeal shall be served on the Director at least ... .

8. $49(1)-$ No prosecution shall be commenced under this Act without...

8. 49(2)-Every prosecution under this Act may be commenced within ...

8. 3(6)-Notwithstanding subsection (5) an owner or bailor may notify a warehouse in writing that he does not accept the contract formed by a warehouse receipt, and such notification must be given within ...

\section{Limitation Period}

24 hours after the birth.

10 days after the birth of such child.

7 days after the finding or taking charge of the child.

10 years after the date of the birth.

2 days after the day of the marriage.

1 year from the day of the marriage.

1 year from the day of the death.

1 year of the refusal of an application for registration by the Director.

1 year of the refusal of the Director for a certificate or search in respect of the registration of the birth, still birth, marriage or death.

1 year thereafter.

30 days prior to the application or appeal.

the consent of the $\mathrm{Min}$ ister.

2 years after the occurrence of the offence, but not thereafter.

20 days after the delivery or mailing of the warehouse receipt. 
Statute

The Warehousemen's Lien Act, R.S.A. 1970 , c. 386

Water, Gas, Electric and Telephone Companies Act, R.S.A. 1970 , c. 387

Water Resources Act, R.S.A. 1970, c. 388

\section{Action or Remedy}

s. 11-Where a warehouseman has information that a person other than the holder of a receipt claims to be the owner or entitled to the goods, the warehouseman may refuse to deliver the goods until he has had a reasonable time to ascertain the validity of the adverse claim or to commence interpleader proceedings, such reasonable time to be not more than ...

8. 5(1)-A warehouseman shall.give notice of the lien to the owner of the goods or to the grantee of the goods under any bill of sale or chattel mortgage, or where the goods on which a lien exists were deposited not. by the owner or by authority of the owner, but by a person entrusted by the owner or by the authority of the owner with the possession of the goods within ...

8. 5(3)-Where the warehouseman fails to give the notice required by this section, his lien, as against the person to whom he has failed to give notice, is void after the expiration of ...

s. 6(5)-A sale for charges that have become due under a lien shall be held not less than ...

8. 8(3)-A warehouseman shall, upon an order of the judge, pay surplus moneys into the Supreme Court where such surplus is not demanded by the person entitled thereto within ...

s. 15-Where a claim is made against a company for damages to crops, gardens, shrubs, trees or other growing things, notice of the claim shall be given in writing signed by the claimant within ...

8. 15(1)-Subject to the provisions of subsection (2), the Minister shall forward a notice of the filing of an application to the secretary-treasurer of the municipality requesting that the notice be posted in a conspicuous and public place in his office for a period of ...

the applicant shall post the notices and keep them posted at two conspicuous points at the site of the proposed works for a period of ...

8. 15(3)-The notice referred to in subsection (2) shall contain a statement of the nature of the rights applied for and of the general character and location of the works and shall be published at least ...

\section{Limitation Period}

10 days.

2 months after the date of the deposit.

2 months from the date of the deposit of the goods.

14 days from the date of the first publication of the advertisement of sale.

10 days after the sale.

a time within which the nature character, extent and evidence of the damage is apparent, and in any case not later than 60 days after the cause for complaint arose.

15 days from the date thereof; and

15 days from the date of posting the notice.

once a week for 2 successive weeks. 
Statute

The Weed Control Act, 1972 , c. 96

The Wildlife Act, R.S.A. 1970 , c. 391

The Women's Institute Act, R.S.A. 1970 , c. 395

\section{Action or Remedy}

s. 15(4)-A person objecting to the granting of an application may file with the Minister a statement of his reasons for objecting within ...

s. 52(3)-No cancellation shall be made by the Minister under subsection (1) or (2) unless the permittee or licensee has been given at least ...

s. 37(3)-The expenses incurred for the destruction of noxious weeds shall be added to the tax roll as an additional tax against the land concerned unless the person or persons on whom a statement of expenses is served fails to either pay the amount set out in the statement or to file a notice of dispute within ...

8. 37(4)-The Council may only proceed against a person by action for the amount owing for expenses where a person to whom a statement or demand for payment is served, files with the municipal secretary a notice of objection within ...

s. $39(1)(e)-A$ notice of appeal shall be in writing and shall be mailed or delivered to the municipal secretary in the case of an appeal from a notice within ...

s. $39(1)(f)-$ Notice of appeal shall be in writing and shall be mailed or delivered to the municipal secretary where an appeal is from an action taken by an inspector, within ...

s. 40-A party to an appeal under section 38 who is dissatisfied with the result, may appeal to the Minister by forwarding a notice of appeal to him within ...

s. 103(1)-A prosecution for an offence under this Act or the regulations shall be commenced within ...

s. 13(1)-A meeting of the members of the Institute shall be held at the call of one of the subscribers who shall be designated by the provincial president within ...

s. 22(1)-Notice of the annual general meeting shall be in writing and be posted by mail to each member at least ...

\section{limitation Period}

30 days from the date of the first publication of the notice in the newspaper, or the date of the posting of the notices in accordance with subsection (1).

30 days notice of the Minister's intention to cancel the preliminary permit or interim licence.

30 days of the mailing of the statement.

the 30 day period referred to in subsection (3).

the time specified in the notice for taking any action or within 15 days, whichever is less.

15 days of such action being taken.

10 days of the date the municipal secretary has mailed the decision to the appellant and the inspector.

1 year after the com. mission of the offence, except in the case of a prosecution for failure to make a return required by this Act or the regulations, when it may be commenced at any time after the offence is alleged to have been com. mitted.

60 days after the incorporation of the Institute.

2 week's prior to the annual general meeting. 
Statute

The Woodmen's Lien Act, R.S.A. 1970, c. 396

The Worker's Compensation Act, 1973 , c. 87

\section{Action or Remedy}

8. 9(1)-If labour or services are performed between the 1st day of October and the 1st day of June next thereafter, the statement of claim shall be filed on or before...

but if such labour or services are done or performed on or after the 1st day of June and before the 1st day of October in any year then the statement shall be filed within ...

8. 9(2)-A - lien remains and is in force against logs, timber or lumber no matter in whose possession the same are found if a mortgage, sale or transfer of the logs is made during ...

8. 10(3)-The lien ceases to be a lien upon the property named in the statement unless proceedings to enforce it are commenced within ...

8. 19-A person served with a copy of a writ of attachment under this Act shall file a notice of dispute in the courts in which proceedings are pending within ...

8. 23-At the conclusion of the inquiry the judge shall make his report and order which shall require the payment of amounts due and costs within ...

8. 24(1)-Logs, timber or lumber shall be sold by the sheriff where there is default of payment into court under section 23 within the said 8 days and the sale shall be held within ...

8. $16(8)$-No compensation shall be paid to a worker unless a claim is made to the Board by the worker within ...

(Note: qualifications of above limitations found in subsection (9)).

s. 16(10)-Where a worker dies after making a claim to the Board, no compensation shall be paid to a dependant unless the dependant makes a claim to the Board within ...

8. 16(11)-Where a worker dies without making a claim to the Board, no compensation shall be paid to a dependant unless

(a) the death occurs within ...

or

(b) the death occurs within ...

\section{Limitation Period}

the 30 th day of the month of June,

30 days after the last day the labour, service or services were performed.

the time limited for the filing of the statement of claim and previous to the filing thereof or after the filing thereof and during the time limited for the enforcement thereof.

30 days after the filing of the statement of claim, or within 30 days of the expiry of the period of credit.

10 days after the service of the writ of attach ment.

8 days after the making of the report and order for payments.

20 days after the expiry of the 8-day period.

1 year of the date of the accident.

3 years after the death of the worker.

1 year of the date of the accident,

3 years of the date of the date of the accident and the conditions contained in subsection (9), clause (a) have been met. 
Statute

\section{Action or Remedy}

8. 17(4)-Notice of the election to claim compensation under the law of a foreign country or compensation under this Act pursuant to subsection (3) shall be given to the Board within ...

or, if it results in death, within ...

s. 19(3)-Every employer to whom this Act applies shall report the occurrence of an accident or shall report the ability or the event of an injured worker returning to work within ...

8. 19(5)-The Board may make a special investigation of the injury and the costs of such investigation may be charged to the employer or other person investigated if the employer or a person who might be an employer fails to reply to the Board's communication in regard to an injured person within ...

s. 57(3)-In any case of silicosis, the limitations as to time contained in section $16(8)$ to (11) do not apply.

8. 67(3)-The person whose duty it is to report building permits for a municipality shall give notice to the Board of all build. ing permits over $\$ 300$ within ...

s. $72(1)-$ When any industry to which this Act applies is established, commenced or recommenced, the employer shall furnish to the Board an estimate of the probable amount of his payroll for the remainder of the year or such other information as the Board may require within ...

8. 73(2)-The employer shall deposit security in the amount and kinds stated in a notice from the Board pursuant to subsection (1) for the payment of the assessments levied or to be levied against him by the Board during the then current year within ...

\section{Limitation Period}

30 days after the happening of the accident.

30 days after the death, or within such longer period as, either before or after the expiration of the 30-day period the Board allows, and if notice of election is not given within the time allowed by this subsection, a claim to com. pensation under this Act shall be presumed to be waived.

24 hours after he receives knowledge of the accident or the ability or happening of the workers return to work.

30 days of the date of such communication.

3 days after the granting of any such building permit.

10 days of the establishment, commencement or recommendation.

15 days after service upon him of notice of such requirement. 


\section{Limitation Period}

8. 81(1)-Where an employer ceases to be an employer within the meaning of this Act, he shall notify the Board by registered mail, and shall at the same time transmit a statement of the total amount of wages earned by his workers for the portion of the then current year during which he has continued in business within ...

8. 87(6)-Where an employer fails to obey an order to close down the whole or any part of his business, the Board may apply to the Supreme Court by way of originating notice for an injunction or other order on not less than...
10 days after ceasing to be an employer.

3 days notice. 